Western University

Scholarship@Western

Chemistry Publications

Chemistry Department

Winter 12-9-2015

\title{
Group 6 Metal Pentacarbonyl Complexes of Air- Stable Primary, Secondary, and Tertiary Ferrocenylethylphosphines
}

Amir Rabiee Kenaree

Ethan R. Sauvé

Paul J. Ragogna

Joe Gilroy

jgilroy5@uwo.ca

Follow this and additional works at: https://ir.lib.uwo.ca/chempub

Part of the Chemistry Commons

Citation of this paper:

Rabiee Kenaree, Amir; Sauvé, Ethan R.; Ragogna, Paul J.; and Gilroy, Joe, "Group 6 Metal Pentacarbonyl Complexes of Air-Stable Primary, Secondary, and Tertiary Ferrocenylethylphosphines" (2015). Chemistry Publications. 71.

https://ir.lib.uwo.ca/chempub/71 


\section{Dalton Transactions}

\section{ARTICLE}

\section{Group 6 Metal Pentacarbonyl Complexes of Air-Stable Primary, Secondary, and Tertiary Ferrocenylethylphosphines}

Received 00th January 20xx, Accepted 00th January 20xx

DOI: $10.1039 / x 0 x \times 00000 x$

www.rsc.org/

\begin{abstract}
Amir Rabiee Kenaree, Ethan R. Sauvé, Paul J. Ragogna and Joe B. Gilroy*
The synthesis and characterization of a series of Group 6 metal pentacarbonyl complexes of air stable primary, secondary, and tertiary phosphines containing ferrocenylethyl substituents are reported $\left[M(C O){ }_{5} \mathrm{~L}: \mathrm{M}=\mathrm{Cr}, \mathrm{Mo}, \mathrm{W} ; \mathrm{L}=\mathrm{PH}_{2}\left(\mathrm{CH}_{2} \mathrm{CH}_{2} \mathrm{Fc}\right)\right.$, $\mathrm{PH}\left(\mathrm{CH}_{2} \mathrm{CH}_{2} \mathrm{Fc}\right)_{2}, \mathrm{P}\left(\mathrm{CH}_{2} \mathrm{CH}_{2} \mathrm{Fc}\right)_{3}$ ]. The structure and composition of the complexes were confirmed by multinuclear $\mathrm{NMR}$ spectroscopy, IR and UV-Vis absorption spectroscopy, mass spectrometry, X-ray crystallography, and elemental analysis. The solid-state structural data reported revealed trends in $\mathrm{M}-\mathrm{C}$ and $\mathrm{M}-\mathrm{P}$ bond lengths that mirrored those of the atomic radii of the Group 6 metals involved. UV-Vis absorption spectroscopy and cyclic voltammetry highlighted characteristics consistent with electronically isolated ferrocene units including wavelengths of maximum absorption between 435 and $441 \mathrm{~nm}$ and reversible one-electron (per ferrocene unit) oxidation waves between 10 and $-5 \mathrm{mV}$ relative to the ferrocene/ferrocenium redox couple. IR spectroscopy confirmed that the $\sigma$ donating ability of the phosphines increased as ferrocenylethyl substituents were introduced and that the tertiary phosphine ligand described is a stronger $\sigma$ donor than $\mathrm{PPh}_{3}$ and a weaker $\sigma$ donor than $\mathrm{PEt}_{3}$, respectively.
\end{abstract}

\section{Introduction}

Phosphines, including examples based on ferrocene, ${ }^{1}$ are among the most widely exploited L-type ligands within the field of coordination chemistry ${ }^{2,3}$ as a result of their tunable steric $^{4}$ and electronic ${ }^{5}$ properties. They have been employed extensively as ancillary and/or labile ligands in homogeneous catalysts [e.g., Grubbs I 1, Ni(dppp) $\mathrm{Cl}_{2}$ 2, $\mathrm{Pd}(\mathrm{dppf}) \mathrm{Cl}_{2} \mathbf{3}$, Wilkinson's catalyst $\mathrm{Rh}\left(\mathrm{PPh}_{3}\right)_{3} \mathrm{Cl}$, and $\left.\mathrm{Pd}\left(\mathrm{PPh}_{3}\right)_{4}\right]$ that rapidly facilitate polymerization, ${ }^{6} \mathrm{C}-\mathrm{C}$ and $\mathrm{C}-\mathrm{E}$ bond formation, ${ }^{7}$ and hydrogenation reactions. ${ }^{8}$ While homogeneous catalysts commonly employ tertiary phosphines, relatively few examples include electron-rich primary and secondary alkyl phosphines due to their high reactivity towards air and moisture.

Building on recent advances surrounding the design and synthesis of air-stable primary, secondary, and tertiary phosphines ${ }^{9,10}$ we have developed a unique series of electronrich alkylphosphines bearing ferrocenylethyl and ruthenocenylethyl substituents (e.g., $\quad 4 a-c) .{ }^{11}$ These phosphines have shown utility as precursors to highlymetallized polymers ${ }^{11 a}$ and polymer networks ${ }^{12}$ and in the phosphane-ene reaction. ${ }^{13}$ They are remarkably stable

Department of Chemistry and the Centre for Advanced Materials and Biomaterials Research (CAMBR), The University of Western Ontario, 1151 Richmond St. N., London, Ontario, Canada, N6A 5B7. Tel: +1-519-661-2111 ext. 81561, E-mail: joe.gilroy@uwo.ca.

Electronic Supplementary Information (ESI) available: NMR and UV-Vis absorption spectra, cyclic voltammograms, and solid-state structures. See DOI: $10.1039 / \times 0 \times x 00000 x$

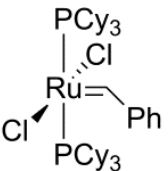

1<smiles>Cl[N+]1(Cl)CCC[Pb]1(Cl)c1ccccc1</smiles>

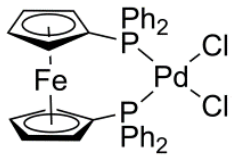

3 towards air and moisture, redox active, and afford the ability to tune their steric properties through the sequential addition of ethylmetallocene units. Herein, we present a comprehensive study of the structure, bonding, and properties of a series of Group 6 metal pentacarbonyl ( $\mathrm{M}=\mathrm{Cr}$, Mo, W) complexes of primary, secondary, and tertiary ferrocenylethylphosphines in order to establish fundamental knowledge of their ligand characteristics. Specifically, these ligands may be particularly well suited for the generation of high nuclearity transition metal clusters, where the presence of ferrocene has previously led to materials with application as sensors and electrode materials. ${ }^{14}$ 


\section{Results and discussion}

\section{Synthesis and NMR spectroscopy}

Primary, secondary, and tertiary ferrocenylethyl phosphines $4 \mathbf{4 a}-\mathbf{c}$ were prepared according to published protocols. ${ }^{11}$ Monosubstituted phosphine complexes of Group 6 metal pentacarbonyls $\left[\mathrm{M}(\mathrm{CO})_{5}, \mathrm{M}=\mathrm{Cr}, \mathrm{Mo}, \mathrm{W}\right]$ were produced by first irradiating commercially available hexacarbonyls in THF with UV light to produce the corresponding THF adducts. The THF adducts were stirred with the appropriate phosphines for $2 \mathrm{~h}$, isolated, and purified via column chromatography to afford phosphine complexes $\mathbf{5 a - c}(\mathrm{M}=\mathrm{Cr}), \mathbf{6 a - c}(\mathrm{M}=\mathrm{Mo})$ and $7 a-c(M=W)$ in yields ranging from 78 to $90 \%$ (Scheme 1 ). The structure and purity of the reported complexes were confirmed using multinuclear NMR spectroscopy, X-ray crystallography, IR and UV-Vis absorption spectroscopy, mass spectrometry, and elemental analysis.

$$
\begin{aligned}
& \left(\mathrm { Fc } \gamma _ { \mathrm { n } } ^ { \mathrm { PH } _ { 3 - \mathrm { n } } } \frac { \mathrm { M } ( \mathrm { CO } ) _ { 5 } \cdot \mathrm { THF } } { \mathrm { THF } } \left(\mathrm{Fc} \gamma_{\mathrm{n}}^{\mathrm{PH}_{3-n} \mathrm{M}(\mathrm{CO})_{5}}\right.\right. \\
& \text { 4a: } n=1 \\
& \text { 4b: } n=2 \\
& \text { 4c: } n=3 \\
& 2 \mathrm{~h} \\
& \begin{array}{l}
\text { 5a-c: } M=C r \\
\text { 6a-c: } M=M o \\
\text { 7a-c: } M=W
\end{array}
\end{aligned}
$$

Scheme 1 Synthesis of primary, secondary, and tertiary phosphine- $\mathrm{M}(\mathrm{CO})_{5}$ complexes $\mathbf{5 a}-\mathbf{c}, \mathbf{6 a - c}$, and $\mathbf{7 a}-\mathrm{c}$. $\mathrm{Fc}=$ ferrocene.

The NMR spectra of phosphine-M(CO) $)_{5}$ complexes $5 a-c$, $\mathbf{6 a}-\mathbf{c}$, and $\mathbf{7 a}-\mathbf{c}$ were consistent with the proposed structures of the complexes, with each phosphine coordinated to a single $\mathrm{M}(\mathrm{CO})_{5}$ fragment (Fig. 1, Figs. S1-S33, and Table 1). The ${ }^{1} \mathrm{H}$ NMR spectra of the complexes confirmed the presence of ligated primary, secondary, and tertiary phosphines and gave rise to two resonances (1.97-2.26 ppm and 2.51-2.77 ppm) attributed to the ethyl linker and a singlet and pair of pseudo triplets (4.04-4.26 ppm) due to the presence monosubstituted ferrocene groups. The phosphine protons were observed as complex doublets between 4.24 and $4.55 \mathrm{ppm}$ for primary phosphine complexes $5 \mathbf{a}, \mathbf{6 a}$, and $7 \mathbf{a}$ and between 4.52 and 4.85 for secondary phosphine complexes $\mathbf{5 b}, \mathbf{6 b}$, and $\mathbf{7 b}$.

${ }^{31} \mathrm{P}$ NMR spectroscopy showed that the phosphorus atoms within the phosphine- $\mathrm{M}(\mathrm{CO})_{5}$ complexes described became increasingly deshielded as the number of ferrocenylethyl groups was increased (e.g., 7a: -101.9 ppm; 7b: -43.6 ppm; and 7c: $-6.8 \mathrm{ppm})$. A second trend emerged when we

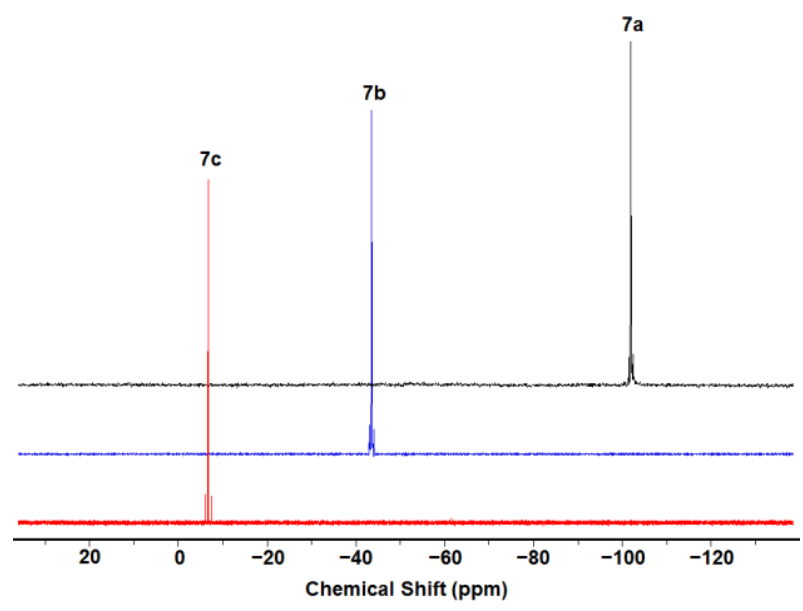

Fig. $1{ }^{31} \mathrm{P}\left\{{ }^{1} \mathrm{H}\right\}$ NMR spectra of primary, secondary, and tertiary phosphine-W(CO) $)_{5}$ complexes $7 a$ (black line), 7 b (blue line), and 7c (red line) recorded in $\mathrm{CDCl}_{3}$.

examined the effect of the transition metal on the ${ }^{31} \mathrm{P} N M R$ shift. The shielding effect of the metals increased as we moved down Group 6 from $\mathrm{Cr}$ to $\mathrm{W}$, resulting in a dramatic upfield shift of the ${ }^{31} \mathrm{P}$ NMR signals (e.g., 5a: -47.7 ppm; 6a: -80.4 ppm; and 7a: $-101.9 \mathrm{ppm})$. The ${ }^{13} \mathrm{C}$ NMR signals observed for the $\mathrm{CO}$ ligands in each complex follow the same trend, with the most upfield resonances being observed for $\mathrm{W}(\mathrm{CO})_{5}$ complexes and the most downfield resonances being observed for the $\mathrm{Cr}(\mathrm{CO})_{5}$ complexes. Coupling to ${ }^{183} \mathrm{~W}\left({ }^{1} J_{\mathrm{PW}}\right.$ for 7a: 217 $\mathrm{Hz}$; 7b: $225 \mathrm{~Hz}$; and 7c: $233 \mathrm{~Hz}$ ) in complexes 7a-c further supports the proposed structures of the complexes and the static nature of the P-W bonds (Figs. S27, S30, and S33). The observed trend for the P-W coupling constants is consistent with previous reports where a linear relationship between $\mathrm{CO}$ stretching frequencies ( $E$ mode) and coupling constants was established (Table 1). ${ }^{15}$

\section{X-ray crystallography}

The solid-state structures of complexes $\mathbf{5 c}, \mathbf{6 c}$, and $\mathbf{7 a - c}$ were determined by single crystal $\mathrm{X}$-ray diffraction and are

\begin{tabular}{|c|c|c|c|c|c|c|c|c|c|}
\hline & $5 a$ & $5 b$ & $5 c$ & $6 a$ & $6 b$ & $6 c$ & $7 a$ & $7 b$ & $7 c$ \\
\hline $\mathrm{v}(\mathrm{CO}) \mathrm{A}_{1 \text { cis }}{ }^{a}$ & 2067 & 2062 & 2058 & 2075 & 2071 & 2067 & 2074 & 2070 & 2066 \\
\hline $\mathrm{v}(\mathrm{CO}) \mathrm{A}_{1 \text { trans }}{ }^{a}$ & 1979 & 1979 & 1975 & 1993 & 1986 & 1981 & 1976 & 1978 & 1974 \\
\hline $\mathrm{v}(\mathrm{CO}) \mathrm{E}^{a}$ & 1916 & 1916 & 1922 & 1922 & 1925 & 1929 & 1912 & 1914 & 1922 \\
\hline${ }^{31} \mathrm{P}(\delta)^{b}$ & -47.7 & 3.5 & 30.4 & -80.4 & -22.9 & 12.5 & -101.9 & -43.6 & -6.8 \\
\hline${ }^{1} J_{\mathrm{PH}}(\mathrm{Hz})^{b}$ & 324 & 321 & - & 319 & 315 & - & 333 & 328 & - \\
\hline${ }^{1} J_{\mathrm{PW}}(\mathrm{Hz})^{b}$ & - & - & - & - & - & - & 217 & 225 & 233 \\
\hline$\lambda_{\max }(\mathrm{nm})^{d}$ & 437 & 436 & 439 & 439 & 436 & 435 & 441 & 437 & 436 \\
\hline$\varepsilon\left(\mathrm{M}^{-1} \mathrm{~cm}^{-1}\right)^{d}$ & 130 & 230 & 350 & 115 & 250 & 350 & 120 & 245 & 335 \\
\hline
\end{tabular}
shown in Figs. 2, S34, and S35 and the data are summarized in Table 2. The structures contain many general features including a group 6 metal in an octahedral environment, $\mathrm{C}$-O bond lengths between 1.138(3) and 1.145(4) $\AA$, and P-C bond

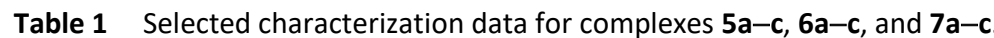

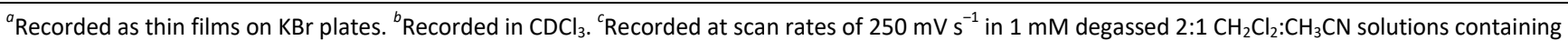
$0.1 \mathrm{M}\left[n-\mathrm{Bu}_{4} \mathrm{~N}\right]\left[\mathrm{SO}_{3} \mathrm{CF}_{3}\right]$ as supporting electrolyte and referenced relative to the ferrocene/ferrocenium redox couple. ${ }^{d} \mathrm{Recorded}$ in $\mathrm{CH}_{2} \mathrm{Cl}_{2}$. 
a

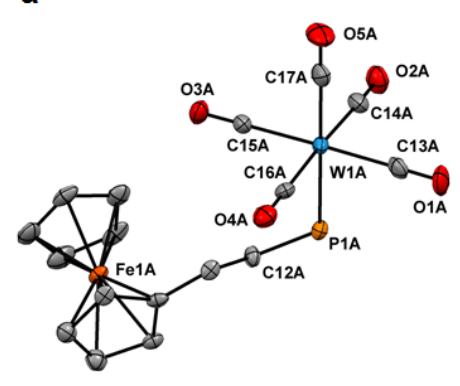

b

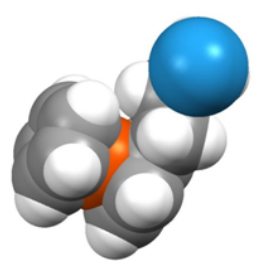

c

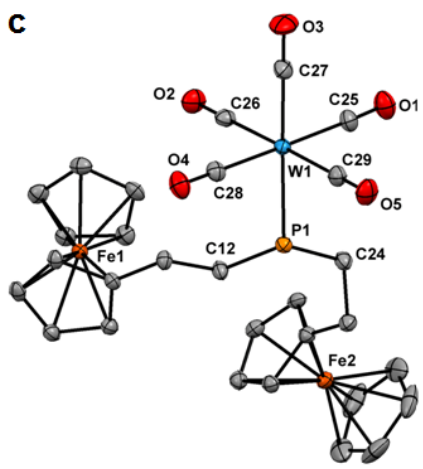

d

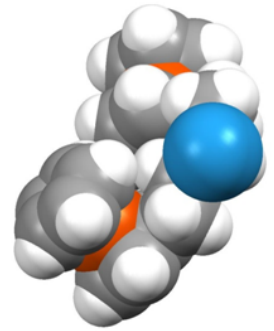

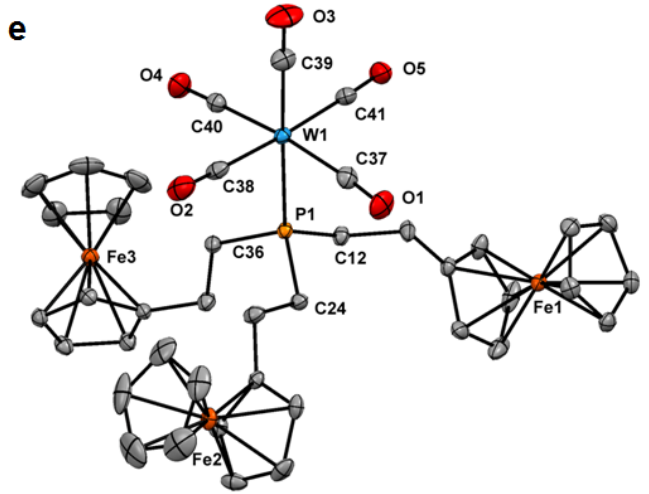

f

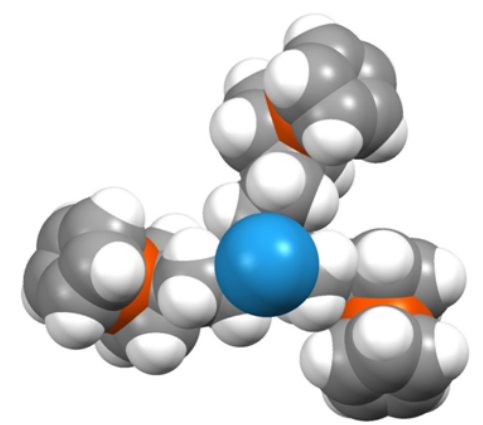

Fig. 2 Solid-state structures and partial spacefill models of primary, secondary, and tertiary phosphine-W(CO) $)_{5}$ complexes $7 a$ $(a, b), 7 b(c, d)$, and $7 c(e, f)$. Anisotropic displacement ellipsoids are shown at $50 \%$ probability and hydrogen atoms have been omitted for clarity. Only one of the two structurally similar molecules from the asymmetric unit for $7 a$ is shown.

Table 2 Selected bond lengths $(\AA)$ and angles for complexes $5 c, 6 c$, and $7 \mathbf{a}-\mathbf{c}$.

\begin{tabular}{llllll}
\hline & $\mathbf{5 c}$ & $\mathbf{6 c}$ & $\mathbf{7 a}$ & $\mathbf{7 b}$ & $\mathbf{7 c}$ \\
\hline trans M-C & $1.866(4)$ & $2.018(4)$ & $2.012(8)$ & $1.998(4)$ & $2.012(2)$ \\
cis M-C (avg) & $1.895(4)$ & $2.041(4)$ & $2.044(8)$ & $2.047(5)$ & $2.041(3)$ \\
M-C (avg) & $1.890(4)$ & $2.036(4)$ & $2.038(8)$ & $2.037(5)$ & $2.035(3)$ \\
M-P & $2.3747(10)$ & $2.5121(11)$ & $2.492(2)$ & $2.5135(10)$ & $2.5094(8)$ \\
trans C-O & $1.149(4)$ & $1.141(4)$ & $1.145(8)$ & $1.156(5)$ & $1.141(3)$ \\
cis C-O (avg) & $1.145(4)$ & $1.144(4)$ & $1.143(8)$ & $1.136(6)$ & $1.138(3)$ \\
C-O (avg) & $1.145(4)$ & $1.144(4)$ & $1.144(8)$ & $1.140(6)$ & $1.138(3)$ \\
P-C (avg) & $1.832(3)$ & $1.833(3)$ & $1.842(7)$ & $1.832(4)$ & $1.832(2)$ \\
C-P-C (avg) & $102.28(15)$ & $102.46(16)$ & - & $104.57(19)$ & $102.62(10)$ \\
\hline
\end{tabular}

${ }^{a}$ The asymmetric unit for $7 \mathrm{a}$ contains two crystallographically independent molecules. Average values for the two molecules are listed.

lengths of 1.832(3)-1.842(7) $\AA$. The P-C bond lengths observed were slightly shorter than those of free phosphines $4 a-c$ $\left[1.843(1)-1.93(1) \AA ̊ .1 .^{11 a}\right.$

Examination of the solid-state structures of $7 a-c(M=W)$ allowed for direct comparison of the primary, secondary, and tertiary phosphine complexes. Partial space filling models, viewed down the $\mathrm{W}-\mathrm{P}$ bond axis, are shown in Fig. 2 and demonstrate the dramatic increase in relative size associated with the sequential addition of ferrocenylethyl substituents at phosphorus. The M-P distances are 2.492(2) $\AA$ for 7a, 2.5135(10) A for 7b, and 2.5094(8) Å for 7c, which provides an indication that the introduction of additional ferrocenylethyl substituents at phosphorus does not result in a significant enhancement in the steric interactions between the phosphine ligands and $\mathrm{M}(\mathrm{CO})_{5}$ unit. A further indication that the structures of the phosphine ligands are not being altered in the complexes due to unfavorable steric interactions are the average C-P-C angles, which increased from $99.03(4)^{\circ}$ and $99.68(6)^{\circ}$ in free phosphines $\mathbf{4 b}$ and $\mathbf{4 c}$ to $104.57(19)^{\circ}$ and $102.62(10)^{\circ}$ in their respective $\mathrm{W}(\mathrm{CO})_{5}$ complexes, $7 \mathbf{b}$ and $7 \mathrm{c}$.

By comparing the solid-state structures of tertiary phosphine complexes $\mathbf{5 c}, \mathbf{6 c}$, and $\mathbf{7 c}$ we assessed the influence of the different Group 6 metals on their structural metrics. The $\mathrm{M}-\mathrm{P}$ bond length observed for complex $5 \mathrm{c}[\mathrm{M}=\mathrm{Cr}, 2.3747$ (10) $\AA]$ was shorter than that of $6 c$ [M = Mo, 2.5121(11) $\AA$ ] due to an increase in the number of electrons associated with a change from Period 4 to Period 5. Similar elongation of the $M$ $P$ bond was not observed when Mo was replaced by $W$ in 7c [2.5094(8) Å] due to the lanthanoid contraction. 


\section{FT-IR spectroscopy}

The assignment of the $\mathrm{CO}$ stretching frequencies [ $\mathrm{U}(\mathrm{CO})]$ of monosubstituted metal carbonyl complexes $\left[\mathrm{M}(\mathrm{CO})_{5} \mathrm{~L}\right]$ and surrounding theory was developed by Orgel and Cotton in the early 1960s. ${ }^{16}$ Based on their findings, we expected to observe three unique $\mathrm{CO}$ stretches $\left(\mathrm{A}_{1 \text { cis }}, \mathrm{A}_{1 \text { trans }}, E\right)$ in the IR spectra of phosphine-M(CO) $)_{5}$ complexes $5 \mathbf{a}-\mathbf{c}, \mathbf{6 a}-\mathbf{c}$, and $\mathbf{7 a - c}$ (Fig. 3, Figs. S36-S44, and Table 1). In general, the $v(\mathrm{CO}) A_{1 \text { cis }}$ $\left(2058-2075 \mathrm{~cm}^{-1}\right)$ and $A_{1 \text { trans }}\left(1974-1993 \mathrm{~cm}^{-1}\right.$ ) absorptions for the complexes were shown to decrease when primary phosphine $\mathbf{4 a}$ was replaced by secondary phosphine $\mathbf{4 b}$ and when secondary phosphine $\mathbf{4 b}$ was replaced by tertiary phosphine 4c. This trend provides evidence that the $\sigma$ donating ability of the phosphine ligands employed in this study, and thus the extent of $\pi$ backbonding to $\mathrm{CO}$, increased as ferrocenylethyl substituents were introduced at the ligand. By comparing the $\mathrm{CO}$ stretching frequencies [ $\left.\mathrm{U}(\mathrm{CO}) \mathrm{A}_{1 \text { trans }}\right]$ observed for tertiary phosphine complexes $\mathbf{5 c}, \mathbf{6 c}$, and $\mathbf{7 c}$ with those recorded for analogous $\mathrm{PEt}_{3}\left(\mathrm{Et}_{3} \mathrm{PCrCO}_{5}: 1943 \mathrm{~cm}^{-1}\right.$; $\left.\mathrm{Et}_{3} \mathrm{PMoCO}_{5}: 1944 \mathrm{~cm}^{-1} ; \mathrm{Et}_{3} \mathrm{PWCO}_{5}: 1943 \mathrm{~cm}^{-1}\right)^{17}$ and $\mathrm{PPh}_{3}$ $\left(\mathrm{Ph}_{3} \mathrm{PCrCO}_{5}: 1989 \mathrm{~cm}^{-1} ; \mathrm{Ph}_{3} \mathrm{PMoCO}_{5}: 1990 \mathrm{~cm}^{-1} ; \mathrm{Ph}_{3} \mathrm{PWCO}_{5}\right.$ : $\left.1981 \mathrm{~cm}^{-1}\right)^{16 b}$ complexes, we conclude that the tertiary phosphine ligand employed in this study is a stronger $\sigma$ donor than the phenyl-substituted analog, but a weaker $\sigma$ donor than the ethyl-substituted analog.

Variation of the transition metals involved provided further insight into the bonding within the series of complexes. The extent of $\pi$ backbonding to the $\mathrm{CO}$ ligands, based on the values of $\mathrm{v}(\mathrm{CO}) \mathrm{A}_{1 \text { trans }}$ and $\mathrm{A}_{1 \mathrm{cis}}$, followed the trend: $\mathrm{Cr}>\mathrm{W}>\mathrm{Mo}$ and mirrored the trend in electronegativities for the metals involved.

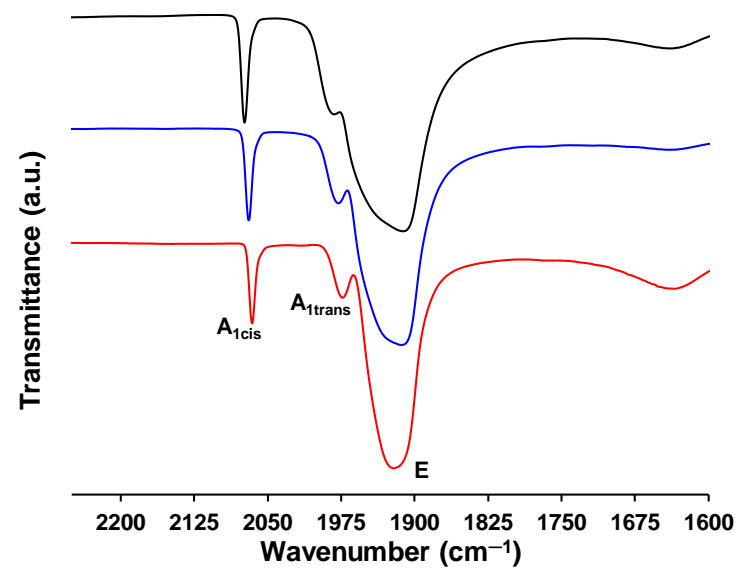

Fig. 3 FT-IR spectra (CO region) for primary, secondary, and tertiary phosphine-W(CO) ${ }_{5}$ complexes $7 a$ (black line), $7 \mathbf{b}$ (blue line), and $7 \mathrm{c}$ (red line) recorded as thin films on $\mathrm{KBr}$ plates.

\section{UV-Vis absorption spectroscopy and cyclic voltammetry}

The UV-Vis absorption spectra and cyclic voltammograms (CVs) recorded for phosphine- $\mathrm{M}(\mathrm{CO})_{5}$ complexes $\mathbf{5 a - c}, \mathbf{6 a - c}$, and $7 \mathrm{a}-\mathbf{c}$ were consistent with the presence of electronically isolated ferrocene groups. Due to the large octahedral field splitting associated with strong field carbonyl ligands, the UV-

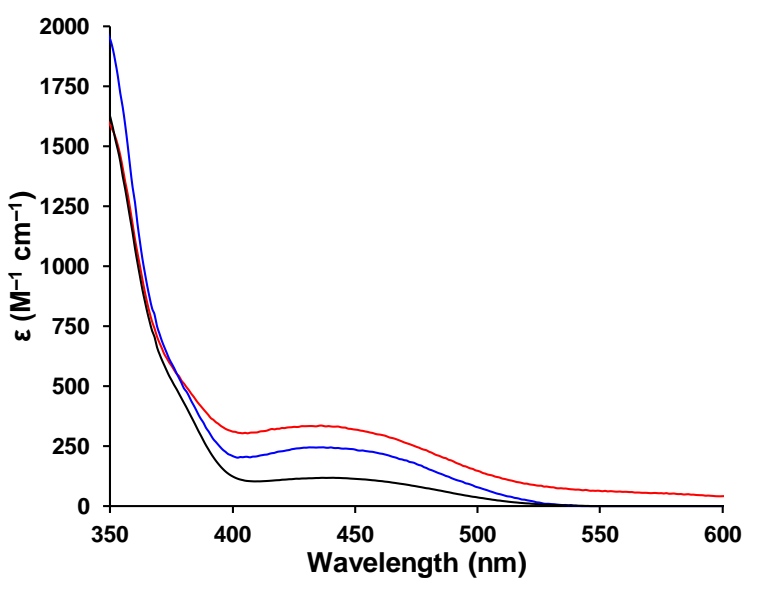

Fig. 4 UV-Vis spectra of primary, secondary, and tertiary phosphine- $\mathrm{W}(\mathrm{CO})_{5}$ complexes $7 \mathbf{a}$ (black line), 7b (blue line), and 7c (red line) recorded in $\mathrm{CH}_{2} \mathrm{Cl}_{2}$.

Vis absorption spectra of phosphine-M(CO) $)_{5}$ complexes $5 a-c$, 6a-c, and $7 a-c$ in $\mathrm{CH}_{2} \mathrm{Cl}_{2}$ are comprised primarily of features associated with the ferrocene moieties (Fig. 4, Figs. S45-S50, and Table 1). For each series of primary, secondary, and tertiary complexes the molar absorptivity $(\varepsilon)$ at the absorption maxima $\left(\lambda_{\max }=435-441 \mathrm{~nm}\right)$ associated with the formally forbidden, $d \rightarrow d$ transitions of ferrocene scaled linearly with the number of ferrocene groups present and ranged from 115 to $350 \mathrm{M}^{-1} \mathrm{~cm}^{-1}$.

The electrochemical properties of phosphine-M(CO) complexes $\mathbf{5 a - c}, \mathbf{6 a}-\mathbf{c}$, and $\mathbf{7 a - c}$ were studied by collecting $\mathrm{CV}$ of $1 \mathrm{mM}$ degassed 2:1 $\mathrm{CH}_{2} \mathrm{Cl}_{2}: \mathrm{CH}_{3} \mathrm{CN}$ solutions containing $0.1 \mathrm{M}\left[n-\mathrm{Bu}_{4} \mathrm{~N}\right]\left[\mathrm{SO}_{3} \mathrm{CF}_{3}\right]$ as supporting electrolyte (Fig. 5, Figs. S51-S58, and Table 1). This solvent/supporting electrolyte combination was required in order to solubilize both the ferrocene and electrogenerated ferrocenium forms of the complexes. When traditional electrolytes (e.g., $\left[n-\mathrm{Bu}_{4} \mathrm{~N}\right]\left[\mathrm{PF}_{6}\right]$ ) were employed in non-polar solvents such as $\mathrm{CH}_{2} \mathrm{Cl}_{2}$, plating of the ferrocenium forms of the complexes resulted in a loss of diffusion control at the interface of the working electrode. For each complex a single reversible oxidation wave with peak currents corresponding to one electron per ferrocene unit was observed. Significantly, the small electrochemical feature observed at ca. $-150 \mathrm{mV}$ vs. $\mathrm{Fc} / \mathrm{Fc}^{+}$in the $\mathrm{CVs}$ of the free phosphines (Fig. 5), which has been previously linked to the presence of the phosphorus lone pair, ${ }^{11}$ disappears upon metal coordination. Within each series complexes the relatively electron-poor primary phosphine complexes $(10 \mathrm{mV})$ were harder to oxidize than the secondary phosphine complexes which contain an additional ferrocenylethyl substituent (0 $\mathrm{mV})$. Furthermore, the relatively electron-rich tertiary phosphine complexes were the easiest to oxidize $(-5 \mathrm{mV})$. All of the complexes reported in this study were more difficult to oxidize than free phosphines $\mathbf{4 a - c}$ under identical conditions $^{11 a}$ and there were no observable differences in the CVs when the transition metals were varied. 


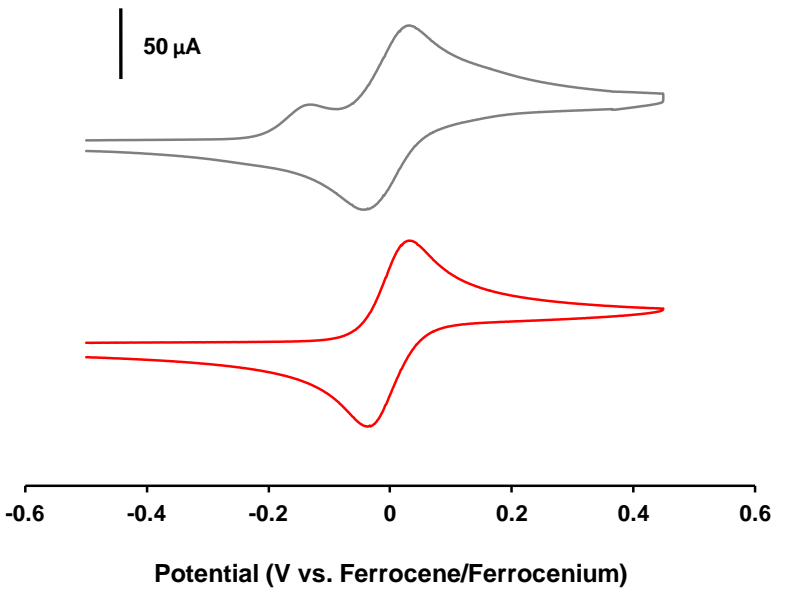

Fig. 5 Cyclic voltammograms of tertiary phosphine 4c (grey line) and tertiary phosphine- $\mathrm{W}(\mathrm{CO})_{5}$ complex 7c (red line) recorded at $250 \mathrm{mV} \mathrm{s}^{-1}$ for $1 \mathrm{mM}$ degassed 2:1 $\mathrm{CH}_{2} \mathrm{Cl}_{2}: \mathrm{CH}_{3} \mathrm{CN}$ solutions containing $0.1 \mathrm{M}\left[n-\mathrm{Bu}_{4} \mathrm{~N}\right]\left[\mathrm{SO}_{3} \mathrm{CF}_{3}\right]$ as supporting electrolyte.

\section{Conclusions}

We have reported the synthesis and characterization of a series of Group $6 \mathrm{M}(\mathrm{CO})_{5}$ complexes of air-stable, redox-active primary, secondary, and tertiary ferrocenylethylphosphines. ${ }^{31} \mathrm{P}$ NMR spectroscopic studies confirmed the phosphine units to be intact in the complexes while X-ray crystallography was used to verify the proposed structures of the complexes and demonstrated trends in $\mathrm{M}-\mathrm{C}$ and $\mathrm{M}-\mathrm{P}$ bond lengths that followed those of the atomic radii of the metals involved. The $\mathrm{X}$-ray structures of complexes $\mathbf{7 a - c}$ also allowed for a qualitative assessment of the relative size of the ligands, showing that the volume occupied by the phosphine ligands increased dramatically with the sequential introduction of additional ferrocenylethyl substituents. UV-Vis absorption spectroscopy and cyclic voltammetry studies confirmed that the ferrocene moieties were electronically isolated from the metals in the complexes studied, and revealed properties consistent with monosubstituted ferrocenes. By monitoring the CO stretches of the complexes with IR spectroscopy, we demonstrated that the $\sigma$ donating ability of the phosphine ligands increased as ferrocenylethyl substituents were introduced [ $\sigma$ donor strength: $\mathrm{P}\left(\mathrm{CH}_{2} \mathrm{CH}_{2} \mathrm{Fc}\right)_{3}>\mathrm{PH}\left(\mathrm{CH}_{2} \mathrm{CH}_{2} \mathrm{Fc}\right)_{2}>$ $\left.\mathrm{PH}_{2}\left(\mathrm{CH}_{2} \mathrm{CH}_{2} \mathrm{FC}\right)\right]$ and that the $\sigma$ donating ability of the phosphines were intermediate between those of ethyl and phenyl phosphines [ $\sigma$ donor strength: $\mathrm{PEt}_{3}>\mathrm{P}\left(\mathrm{CH}_{2} \mathrm{CH}_{2} \mathrm{Fc}\right)_{3}>$ $\left.\mathrm{PPh}_{3}\right]$.

Based on the fundamental knowledge of the ligand characteristics of this promising class of ferrocenylethyl phosphine ligands produced as a result of this work, we are hopeful that they will be employed by those working towards novel homogeneous catalysts and redox-active coordination complexes. Our future work in this area will focus on their use in the coordination chemistry of late transition metal chalcogens as we pursue large, redox-active transition metal clusters.

\section{Experimental section}

\section{General considerations}

All reactions and manipulations were carried out under a nitrogen atmosphere using standard glove box or Schlenk techniques unless otherwise stated. Solvents were obtained from Caledon Laboratories, dried using an Innovative Technologies Inc. solvent purification system, collected under vacuum, and stored under a nitrogen atmosphere over $4 \AA$ molecular sieves. All reagents were purchased from SigmaAldrich or Alfa Aesar and used as received, aside from metal carbonyls which were sublimed before use. Primary, secondary, and tertiary phosphines $\mathbf{4 a - c}$ were synthesized according to previously reported protocols. ${ }^{11}$ UV irradiation experiments were conducted with a medium pressure mercury lamp in a Quartz housing with reaction flasks mounted approximately $10 \mathrm{~cm}$ from the lamp. ${ }^{1} \mathrm{H},{ }^{13} \mathrm{C}$, and ${ }^{31} \mathrm{P} N M R$ spectra were recorded on a $600 \mathrm{MHz}\left({ }^{1} \mathrm{H}\right.$ : $599.5 \mathrm{MHz},{ }^{13} \mathrm{C}$ : $150.8 \mathrm{MHz},{ }^{31} \mathrm{P}: 242.6 \mathrm{MHz}$ ) Varian INOVA instrument. ${ }^{1} \mathrm{H} \mathrm{NMR}$ spectra were referenced to residual $\mathrm{CHCl}_{3}$ (7.27 ppm) and ${ }^{13} \mathrm{C}\left\{{ }^{1} \mathrm{H}\right\}$ NMR spectra were referenced to $\mathrm{CDCl}_{3}$ (77.0 ppm). ${ }^{31} \mathrm{P}$ $\mathrm{NMR}$ spectra were referenced to $\mathrm{PPh}_{3}$, as an internal standard (-6.0 ppm relative to $\mathrm{H}_{3} \mathrm{PO}_{4}$ ). Mass spectrometry data were recorded in positive-ion mode using a high resolution Finnigan MAT 8400 spectrometer. UV-Vis spectra were recorded using a Cary 300 Scan instrument. Infrared spectra were recorded using a PerkinElmer Spectrum Two FT-IR spectrometer as thin films on $\mathrm{KBr}$ plates. Elemental analyses $(\mathrm{C}$ and $\mathrm{H}$ ) were carried out by Laboratoire d'Analyse Élémentaire de l'Université de Montréal, Montréal, QC, Canada.

\section{Cyclic voltammetry}

CVs were collected using a Bioanalytical Systems Inc. (BASi) Epsilon potentiostat and analyzed using BASi Epsilon software. Typical electrochemical cells consisted of a three-electrode setup including a glassy carbon working electrode, platinum wire counter electrode, and silver wire pseudo-reference electrode. Experiments were run at a scan rate of $250 \mathrm{mV} \mathrm{s}^{-1}$ in degassed 2:1 $\mathrm{CH}_{2} \mathrm{Cl}_{2}: \mathrm{CH}_{3} \mathrm{CN}$ solutions of the analyte ( $\sim \mathrm{mM}$ ) and supporting electrolyte $\left(0.1 \mathrm{M}\left[n-\mathrm{Bu}_{4} \mathrm{~N}\right]\left[\mathrm{SO}_{3} \mathrm{CF}_{3}\right]\right)$ under a blanket of argon. CVs were referenced relative to a decamethylferrocene internal standard (1 mM, -520 mV relative to ferrocene/ferrocenium under identical conditions) and corrected for internal cell resistance using the BASi Epsilon software.

\section{X-ray crystallography}

Single crystals of $\mathbf{5 c}, \mathbf{7 b}$, and $\mathbf{7 c}$ suitable for $\mathrm{X}$-ray diffraction studies were grown by slow evaporation of concentrated $\mathrm{Et}_{2} \mathrm{O}$ solutions. Crystals of $6 c$ were grown by slow diffusion of hexanes into a concentrated THF solution and crystals of $7 \mathrm{a}$ were grown by slow diffusion of pentane into a concentrated 
Table 3 Selected X-ray diffraction data collection and refinement details for complexes $\mathbf{5 c}, \mathbf{6 c}$, and $\mathbf{7 a - c}$.

\begin{tabular}{|c|c|c|c|c|c|}
\hline & $5 c$ & $6 c$ & $7 a$ & $7 b$ & 7c \\
\hline Chemical formula & $\mathrm{C}_{41} \mathrm{H}_{39} \mathrm{CrFe}_{3} \mathrm{O}_{5} \mathrm{P}$ & $\mathrm{C}_{41} \mathrm{H}_{39} \mathrm{Fe}_{3} \mathrm{MoO}_{5} \mathrm{P}$ & $\mathrm{C}_{17} \mathrm{H}_{15} \mathrm{FeO}_{5} \mathrm{PW}$ & $\mathrm{C}_{29} \mathrm{H}_{27} \mathrm{Fe}_{2} \mathrm{O}_{5} \mathrm{PW}$ & $\mathrm{C}_{41} \mathrm{H}_{39} \mathrm{Fe}_{3} \mathrm{O}_{5} \mathrm{PW}$ \\
\hline $\mathrm{FW}\left(\mathrm{g} \mathrm{mol}^{-1}\right)$ & 862.24 & 906.18 & 569.96 & 782.02 & 994.09 \\
\hline Temp (K) & 110 & 110 & 110 & 110 & 110 \\
\hline Crystal system & monoclinic & monoclinic & monoclinic & monoclinic & monoclinic \\
\hline Crystal habit & orange prism & yellow prism & yellow plate & yellow prism & orange prism \\
\hline Space group & $\mathrm{C} 2 / \mathrm{c}$ & $\mathrm{C} 2 / \mathrm{c}$ & $\mathrm{P} 2_{1} / \mathrm{c}$ & $\mathrm{P} 2_{1} / \mathrm{c}$ & $\mathrm{C} 2 / \mathrm{c}$ \\
\hline$\lambda(\AA)$ & 1.54178 & 0.71073 & 0.71073 & 0.71073 & 0.71073 \\
\hline a $(\AA ̊)$ & $20.142(3)$ & $20.300(8)$ & $20.416(7)$ & $17.504(2)$ & $20.307(6)$ \\
\hline b $(\AA ̊)$ & $15.184(2)$ & $15.312(5)$ & $7.239(3)$ & $12.9315(14)$ & $15.287(5)$ \\
\hline$c(\AA)$ & $25.001(6)$ & $25.118(10)$ & $25.066(9)$ & $12.708(2)$ & $25.101(7)$ \\
\hline$\alpha$ (deg) & 90 & 90 & 90 & 90 & 90 \\
\hline$\beta$ (deg) & $104.581(9)$ & $104.367(10)$ & $97.888(15)$ & $109.260(5)$ & $104.391(13)$ \\
\hline$\gamma$ (deg) & 90 & 90 & 90 & 90 & 90 \\
\hline$V\left(\AA^{3}\right)$ & $7400(2)$ & $7563(5)$ & $3669(2)$ & $2715.5(6)$ & $7548(4)$ \\
\hline Z & 8 & 8 & 8 & 4 & 8 \\
\hline$\rho\left(\mathrm{g} \mathrm{cm}^{-3}\right)$ & 1.548 & 1.592 & 2.063 & 1.913 & 1.750 \\
\hline$\mu\left(\mathrm{cm}^{-1}\right)$ & 12.369 & 1.538 & 7.166 & 5.377 & 4.254 \\
\hline $\mathrm{R}_{1}[\mathrm{I}>2 \sigma(\mathrm{I})]$ & 0.0350 & 0.0312 & 0.0379 & 0.0412 & 0.0381 \\
\hline$\omega \mathrm{R}_{2}[\mathrm{I}>2 \sigma(\mathrm{I})]$ & 0.0772 & 0.0633 & 0.0631 & 0.0971 & 0.0688 \\
\hline $\mathrm{R}_{1}$ (all data) & 0.0460 & 0.0456 & 0.0615 & 0.0684 & 0.0670 \\
\hline$\omega \mathrm{R}_{2}$ (all data) & 0.0818 & 0.0691 & 0.0686 & 0.1115 & 0.0757 \\
\hline GOF & 1.045 & 1.042 & 1.063 & 1.019 & 1.062 \\
\hline
\end{tabular}

$\mathrm{R}_{1}=\Sigma\left(\left|\mathrm{F}_{\mathrm{o}}\right|-\left|\mathrm{F}_{\mathrm{c}}\right|\right) / \Sigma \mathrm{F}_{\mathrm{o}}, \omega \mathrm{R}_{2}=\left[\Sigma\left(\omega\left(\mathrm{F}_{\mathrm{o}}{ }^{2}-\mathrm{F}_{\mathrm{c}}{ }^{2}\right)^{2}\right) / \Sigma\left(\omega \mathrm{F}_{\mathrm{o}}{ }^{4}\right)\right]^{1 / 2} ; \mathrm{GOF}=\left[\Sigma\left(\omega\left(\mathrm{F}_{\mathrm{o}}{ }^{2}-\mathrm{F}_{\mathrm{c}}{ }^{2}\right)^{2}\right) /(\text { No. of reflns. }- \text { No. of params. })\right]^{1 / 2}$.

$\mathrm{CHCl}_{3}$ solution. The samples were mounted on a MiTeGen polyimide micromount with a small amount of Paratone $\mathrm{N}$ oil. $\mathrm{X}$-ray measurements for $\mathbf{6 c}$ and $\mathbf{7 a - c}$ were made on a Bruker Apexll CCD diffractometer. Measurements for $\mathbf{5 c}$ were made on a Nonius KappaCCD Apexll diffractometer. The unit cell dimensions were determined from a symmetry constrained fit of 5928 reflections with $7.30^{\circ}<2 \theta<121.36^{\circ}$ for $5 \mathrm{c}$, 9131 reflections with $5.58^{\circ}<2 \theta<46.98^{\circ}$ for 6 c, 9155 reflections with $5.86^{\circ}<2 \theta<49.02^{\circ}$ for $7 a, 9530$ reflections with $7.48^{\circ}<$ $2 \theta<64.96^{\circ}$ for $7 \mathbf{b}$, and 9801 reflections with $5.58^{\circ}<2 \theta<$ $65.90^{\circ}$ for 7c. The data collection strategy was a number of $\omega$ and $\phi$ scans which collected data up to $121.410^{\circ}(2 \theta)$ for $\mathbf{5 c}$, $47.242^{\circ}(2 \theta)$ for $6 c, 50.758^{\circ}(2 \theta)$ for $7 a, 72.758^{\circ}(2 \theta)$ for $7 b$, and $72.824^{\circ}(2 \theta)$ for $7 c$, respectively. The frame integration was performed using SAINT. ${ }^{18}$ The resulting raw data were scaled and absorption corrected using a multi-scan averaging of symmetry equivalent data using SADABS, ${ }^{19}$ except the data for $\mathbf{7 b}$ which were processed using TWINABS. ${ }^{20}$ The twin law for $\mathbf{7 b}$ was derived from the two orientation matrices using the GNU Octave program ${ }^{21}$ and was determined to be:

$\begin{array}{lll}-0.986857 & -0.045843 & -0.154954 \\ -0.045946 & -0.839733 & 0.541052 \\ -0.154923 & 0.541061 & 0.826590\end{array}$

which represents a $180^{\circ}$ rotation about $[1-1-1]$. The twin fraction refined to a value of $0.44883(63)$. The structures for 5c, 6c, 7a, 7b, and 7c were solved by using a dual space methodology using the SHELXT program. ${ }^{22}$ All non-hydrogen atoms were obtained from the initial solution. The hydrogen atoms were introduced at idealized positions and were allowed to ride on the parent atom aside for $\mathbf{6 c}$ where they were treated in a mixed fashion. The structural models were fit to the data using full matrix least-squares based on $F^{2}$. The calculated structure factors included corrections for anomalous dispersion from the usual tabulation. The structures were refined using the SHELXL-2014 program from the SHELX suite of crystallographic software. ${ }^{23}$ For complex 7a, the minor component of the rotational disorder associated with the unsubstituted $\mathrm{Cp}$ ligands could not be fully resolved (see .cif file for details). Graphic plots were produced using Mercury (v3.3). Structural data has been deposited in the CCDC (1423358-1423362). For additional collection and refinement details, see Table 3.

\section{Representative procedure for the preparation of $M(C O)_{5}$ complexes of $5 a-c, 6 a-c, 7 a-c$.}

\section{Primary phosphine complex 5a $(\mathrm{M}=\mathrm{Cr})$}

$\mathrm{Cr}(\mathrm{CO})_{6}(0.268 \mathrm{~g}, 1.22 \mathrm{mmol}, 5$ equiv.) was dissolved in $15 \mathrm{~mL}$ dry THF in a sealed $1 \mathrm{~L}$ Pyrex flask and irradiated with UV light for $2.5 \mathrm{~h}$ to produce an orange solution containing $\mathrm{Cr}(\mathrm{CO})_{5} \mathrm{THF}$. The flask was opened inside a glove box and a solution of $4 \mathrm{a}(0.060 \mathrm{~g}, 0.244$ $\mathrm{mmol}$ ) in $15 \mathrm{~mL}$ dry THF was added dropwise over a 5 min period. The resulting solution was allowed to stir for $2 \mathrm{~h}$ before the solvent was removed under reduced pressure. The reaction mixture was combined with diethyl ether $(5 \mathrm{~mL})$ and the mixture filtered to remove excess $\operatorname{Cr}(\mathrm{CO})_{6}$. The filtrate was then mixed with Celite, concentrated in vacuo, and transferred to the top of a silica column 
$\left(1^{\prime \prime} \times 4^{\prime \prime}\right)$. Using flash column chromatography and a gradient solvent strategy, residual $\operatorname{Cr}(\mathrm{CO})_{6}$, and 5 a were separated. Using 4:1 hexanes:dichloromethane as eluent, 5a $\left(R_{f}=0.36\right)$ was isolated from the column before $\mathrm{Cr}(\mathrm{CO})_{6}$ was eluted using hexanes $\left(\mathrm{R}_{\mathrm{f}}=\right.$ 0.68). The solution containing 5 a was concentrated in vacuo to yield an orange solid. Yield $=0.090 \mathrm{~g}, 84 \%$. M.p. $74-76{ }^{\circ} \mathrm{C} .{ }^{1} \mathrm{H}$ NMR $\left(\mathrm{CDCl}_{3}\right): \delta 4.28$ (d of m, $\left.{ }^{1} J_{\mathrm{HP}}=324 \mathrm{~Hz}, 2 \mathrm{H}, \mathrm{PH}_{2}\right), 4.14\left(\mathrm{~s}, 5 \mathrm{H}, \mathrm{C}_{5} \mathrm{H}_{5}\right.$ ), $4.13\left(\mathrm{~s}, 2 \mathrm{H}, \beta-\mathrm{C}_{5} \mathrm{H}_{4} \mathrm{R}\right), 4.11\left(\mathrm{~s}, 2 \mathrm{H}, \alpha-\mathrm{C}_{5} \mathrm{H}_{4} \mathrm{R}\right), 2.72\left(\mathrm{~m}, 2 \mathrm{H}, \mathrm{C}_{5} \mathrm{H}_{4} \mathrm{CH}_{2}\right)$, $2.04\left(\mathrm{~m}, 2 \mathrm{H}, \mathrm{CH}_{2} \mathrm{PH}_{2}\right) \cdot{ }^{13} \mathrm{C}\left\{{ }^{1} \mathrm{H}\right\} \operatorname{NMR}\left(\mathrm{CDCl}_{3}\right): \delta 220.3\left(\mathrm{~d},{ }^{2} \mathrm{~J}_{\mathrm{CP}}=7 \mathrm{~Hz}\right.$, cis-CO), $216.0\left(\mathrm{~d},{ }^{2} \mathrm{~J}_{\mathrm{CP}}=14 \mathrm{~Hz}\right.$, trans-CO), $86.8\left(\mathrm{~d},{ }^{3} \mathrm{~J}_{\mathrm{CP}}=10 \mathrm{~Hz}\right.$, ipso$\left.C_{5} \mathrm{H}_{4} \mathrm{R}\right), 68.6\left(\mathrm{~s}, \mathrm{C}_{5} \mathrm{H}_{5}\right), 68.1\left(\mathrm{~s}, \alpha-\mathrm{C}_{5} \mathrm{H}_{4} \mathrm{R}\right), 67.8\left(\mathrm{~s}, \beta-\mathrm{C}_{5} \mathrm{H}_{4} \mathrm{R}\right), 30.5$ (d, $\left.{ }^{2} J_{\mathrm{CP}}=7 \mathrm{~Hz}, \mathrm{C}_{5} \mathrm{H}_{4} \mathrm{CH}_{2}\right), 23.4\left(\mathrm{~d},{ }^{1} \mathrm{~J}_{\mathrm{CP}}=25 \mathrm{~Hz}, \mathrm{CH}_{2} \mathrm{PH}_{2}\right) .{ }^{31} \mathrm{P} \mathrm{NMR}\left(\mathrm{CDCl}_{3}\right)$ : $\delta-47.7$ (t of $m,{ }^{1} J_{\mathrm{PH}}=324 \mathrm{~Hz}$ ). FT-IR: $2329(\mathrm{w}), 2067(\mathrm{~m}), 1979(\mathrm{w})$, $1916(s), 1105(w), 1090(w), 1000(w), 926(w), 821(w), 674(m)$, $649(\mathrm{~m}) \mathrm{cm}^{-1}$. UV-Vis $\left(\mathrm{CH}_{2} \mathrm{Cl}_{2}\right): \lambda_{\max } 437 \mathrm{~nm}\left(\varepsilon=130 \mathrm{M}^{-1} \mathrm{~cm}^{-1}\right)$. Mass Spec. (El, +ve mode): exact mass calculated for $\left[\mathrm{C}_{17} \mathrm{H}_{15}{ }^{52} \mathrm{Cr}^{56} \mathrm{FeO}_{5} \mathrm{P}\right]^{+}$: 437.9412; exact mass found: 437.9418; difference: +1.4 ppm. Anal. Calcd. (\%) for $\mathrm{C}_{17} \mathrm{H}_{15} \mathrm{CrFeO}_{5} \mathrm{P}$ : $\mathrm{C}, 46.60 ; \mathrm{H}, 3.45$. Found: $\mathrm{C}, 46.66 ; \mathrm{H}$, 3.47 .

\section{Secondary phosphine complex $5 \mathrm{~b}(\mathrm{M}=\mathrm{Cr})$}

From $\mathrm{Cr}(\mathrm{CO})_{6}(0.240 \mathrm{~g}, 1.09 \mathrm{mmol}, 5$ equiv.) and phosphine $\mathbf{4 b}$ $(0.100 \mathrm{~g}, 0.218 \mathrm{mmol})$. Yield $=0.108 \mathrm{~g}, 80 \%$ of orange solid $\left(R_{f}=\right.$ 0.23). M.p. $88-90{ }^{\circ} \mathrm{C} .{ }^{1} \mathrm{H} N M R\left(\mathrm{CDCl}_{3}\right): \delta 4.52$ (d of $\mathrm{m}^{1}{ }^{1} J_{\mathrm{HP}}=322 \mathrm{~Hz}$, $1 \mathrm{H}, \mathrm{PH}), 4.13\left(\mathrm{~s}, 10 \mathrm{H}, \mathrm{C}_{5} \mathrm{H}_{5}\right), 4.12\left(\mathrm{~s}, 4 \mathrm{H}, \beta-\mathrm{C}_{5} H_{4} \mathrm{R}\right), 4.11(\mathrm{~s}, 4 \mathrm{H}, \alpha-$ $\left.\mathrm{C}_{5} \mathrm{H}_{4} \mathrm{R}\right), 2.63\left(\mathrm{~m}, 4 \mathrm{H}, \mathrm{C}_{5} \mathrm{H}_{4} \mathrm{CH}_{2}\right), 2.09\left(\mathrm{~m}, 4 \mathrm{H}, \mathrm{CH}_{2} \mathrm{PH}\right) .{ }^{13} \mathrm{C}\left\{{ }^{1} \mathrm{H}\right\} \mathrm{NMR}$ $\left(\mathrm{CDCl}_{3}\right): \delta 220.7\left(\mathrm{~d},{ }^{2} \mathrm{~J}_{\mathrm{CP}}=7 \mathrm{~Hz}\right.$, cis-CO), $216.8\left(\mathrm{~d},{ }^{2} \mathrm{~J}_{\mathrm{CP}}=14 \mathrm{~Hz}\right.$, transCO), $87.4\left(\mathrm{~d},{ }^{3} J_{\mathrm{CP}}=13 \mathrm{~Hz}\right.$, ipso- $\left.\mathrm{C}_{5} \mathrm{H}_{4} \mathrm{R}\right), 68.6\left(\mathrm{~s}, \mathrm{C}_{5} \mathrm{H}_{5}\right), 67.8\left(\mathrm{~d},{ }^{4} J_{\mathrm{CP}}=16\right.$ $\left.\mathrm{Hz}, \alpha-C_{5} \mathrm{H}_{4} \mathrm{R}\right), 67.6\left(\mathrm{~s}, \beta-\mathrm{C}_{5} \mathrm{H}_{4} \mathrm{R}\right), 27.4\left(\mathrm{~d},{ }^{1} J_{\mathrm{CP}}=22 \mathrm{~Hz}, \mathrm{CH}_{2} \mathrm{PH}\right), 26.6(\mathrm{~d}$, $\left.{ }^{2} J_{\mathrm{CP}}=2 \mathrm{~Hz}, \mathrm{C}_{5} \mathrm{H}_{4} \mathrm{CH}_{2}\right) .{ }^{31} \mathrm{P}$ NMR $\left(\mathrm{CDCl}_{3}\right): \delta 3.5\left(\mathrm{~d}\right.$ of $\mathrm{m},{ }^{1} \mathrm{~J}_{\mathrm{PH}}=321 \mathrm{~Hz}$ ). FT-IR: $2922(w), 2062(\mathrm{~m}), 1979(w), 1916(\mathrm{~s}), 1637(\mathrm{~m}), 1105(\mathrm{w})$, $999(w), 817(w), 676(w), 651(w) \mathrm{cm}^{-1}$. UV-Vis $\left(\mathrm{CH}_{2} \mathrm{Cl}_{2}\right): \lambda_{\max } 436$ $\mathrm{nm}\left(\varepsilon=230 \mathrm{M}^{-1} \mathrm{~cm}^{-1}\right)$. Mass Spec. (El, +ve mode): exact mass calculated for $\left[\mathrm{C}_{29} \mathrm{H}_{27}{ }^{52} \mathrm{Cr}^{56} \mathrm{Fe}_{2} \mathrm{O}_{5} \mathrm{P}\right]^{+}$: 649.9700; exact mass found: 649.9677; difference: -3.5 ppm. Anal. Calcd. (\%) for $\mathrm{C}_{29} \mathrm{H}_{27} \mathrm{CrFe}_{2} \mathrm{O}_{5} \mathrm{P}$ : C, 53.57; H, 4.19. Found: C, 53.68; H, 4.24.

\section{Tertiary phosphine complex $5 \mathrm{c}(\mathrm{M}=\mathrm{Cr})$}

From $\mathrm{Cr}(\mathrm{CO})_{6}(0.246 \mathrm{~g}, 1.12 \mathrm{mmol}, 5$ equiv.) and phosphine $4 \mathrm{c}$ $(0.150 \mathrm{~g}, 0.224 \mathrm{mmol})$. Yield $=0.145 \mathrm{~g}, 78 \%$ of orange solid $\left(\mathrm{R}_{\mathrm{f}}=\right.$ 0.14). M.p. $140-142{ }^{\circ} \mathrm{C} .{ }^{1} \mathrm{H}$ NMR $\left(\mathrm{CDCl}_{3}\right): \delta 4.18\left(\mathrm{~s}, 15 \mathrm{H}, \mathrm{C}_{5} \mathrm{H}_{5}\right), 4.17$ (s, $12 \mathrm{H}, \alpha-\mathrm{C}_{5} \mathrm{H}_{4} \mathrm{R}$ and $\left.\beta-\mathrm{C}_{5} \mathrm{H}_{4} \mathrm{R}\right), 2.61\left(\mathrm{~m}, 6 \mathrm{H}, \mathrm{C}_{5} \mathrm{H}_{4} \mathrm{CH}_{2}\right), 2.08(\mathrm{~m}, 6 \mathrm{H}$, $\left.\mathrm{CH}_{2} \mathrm{P}\right) .{ }^{13} \mathrm{C}\left\{{ }^{1} \mathrm{H}\right\}$ NMR $\left(\mathrm{CDCl}_{3}\right): \delta 220.9\left(\mathrm{~d},{ }^{2} J_{\mathrm{CP}}=7 \mathrm{~Hz}\right.$, cis-CO), $217.5(\mathrm{~d}$, ${ }^{2} J_{C P}=14 \mathrm{~Hz}$, trans-CO), $87.9\left(\mathrm{~d},{ }^{3} J_{\mathrm{CP}}=15 \mathrm{~Hz}\right.$, ipso- $\left.\mathrm{C}_{5} \mathrm{H}_{4} \mathrm{R}\right), 68.6(\mathrm{~s}$, $\left.C_{5} \mathrm{H}_{5}\right), 67.7\left(\mathrm{~s}, \alpha-C_{5} \mathrm{H}_{4} \mathrm{R}\right), 67.6\left(\mathrm{~s}, \beta-\mathrm{C}_{5} \mathrm{H}_{4} \mathrm{R}\right), 30.6\left(\mathrm{~d},{ }^{1} J_{\mathrm{CP}}=18 \mathrm{~Hz}, \mathrm{CH}_{2} \mathrm{P}\right)$, $23.8\left(\mathrm{~s}, \mathrm{C}_{5} \mathrm{H}_{4} \mathrm{CH}_{2}\right) .{ }^{31} \mathrm{P} \mathrm{NMR}\left(\mathrm{CDCl}_{3}\right): \delta 30.4(\mathrm{~m})$. FT-IR: $3092(\mathrm{w}), 2928$ $(w), 2058(m), 1975(w), 1922(s), 1635(w), 1411(w), 1106(w)$, $1000(w), 818(w), 755(w), 677(m), 655(\mathrm{~m}) \mathrm{cm}^{-1}$. UV-Vis $\left(\mathrm{CH}_{2} \mathrm{Cl}_{2}\right)$ : $\lambda_{\max } 439 \mathrm{~nm}\left(\varepsilon=350 \mathrm{M}^{-1} \mathrm{~cm}^{-1}\right)$. Mass Spec. (El, +ve mode): exact mass calculated for $\left[\mathrm{C}_{41} \mathrm{H}_{39}{ }^{52} \mathrm{Cr}^{56} \mathrm{Fe}_{3} \mathrm{O}_{5} \mathrm{P}\right]^{+}$: 861.9988; exact mass found: 861.9966; difference: $-2.6 \mathrm{ppm}$. Anal. Calcd. (\%) for $\mathrm{C}_{41} \mathrm{H}_{39} \mathrm{CrFe}_{3} \mathrm{O}_{5} \mathrm{P}: \mathrm{C}, 57.11 ; \mathrm{H}, 4.56$. Found: $\mathrm{C}, 57.11 ; \mathrm{H}, 4.62$.

\section{Primary phosphine complex $6 \mathrm{a}(\mathrm{M}=\mathrm{Mo})$}

From $\mathrm{Mo}(\mathrm{CO})_{6}(0.322 \mathrm{~g}, 1.22 \mathrm{mmol}, 5$ equiv.) and phosphine $4 \mathrm{a}$ $(0.060 \mathrm{~g}, 0.244 \mathrm{mmol})$. Yield $=0.087 \mathrm{~g}, 79 \%$ of orange solid $\left(R_{\mathrm{f}}=\right.$ 0.35). M.p. $56-58{ }^{\circ} \mathrm{C} .{ }^{1} \mathrm{H} N M R\left(\mathrm{CDCl}_{3}\right): \delta 4.24$ (d of $\mathrm{m},{ }^{1} J_{\mathrm{HP}}=319 \mathrm{~Hz}$, $\left.2 \mathrm{H}, \mathrm{PH} \mathrm{H}_{2}\right), 4.13\left(\mathrm{~s}, 5 \mathrm{H}, \mathrm{C}_{5} \mathrm{H}_{5}\right.$ ), 4.12 (pseudo-t, ${ }^{3} \mathrm{~J}_{\mathrm{HH}}=2 \mathrm{~Hz}, 2 \mathrm{H}, \beta-\mathrm{C}_{5} \mathrm{H}_{4} \mathrm{R}$ ),
4.11 (pseudo-t, $\left.{ }^{3} \mathrm{~J}_{\mathrm{HH}}=2 \mathrm{~Hz}, 2 \mathrm{H}, \alpha-\mathrm{C}_{5} \mathrm{H}_{4} \mathrm{R}\right), 2.70\left(\mathrm{~m}, 2 \mathrm{H}, \mathrm{C}_{5} \mathrm{H}_{4} \mathrm{CH}_{2}\right), 2.02$ $\left(\mathrm{m}, 2 \mathrm{H}, \mathrm{CH}_{2} \mathrm{PH}_{2}\right) \cdot{ }^{13} \mathrm{C}\left\{{ }^{1} \mathrm{H}\right\} \mathrm{NMR}\left(\mathrm{CDCl}_{3}\right): \delta 208.7\left(\mathrm{~d},{ }^{2} J_{\mathrm{CP}}=23 \mathrm{~Hz}\right.$, cisCO), $204.9\left(\mathrm{~d},{ }^{2} J_{\mathrm{CP}}=9 \mathrm{~Hz}\right.$, trans-CO), $86.9\left(\mathrm{~d},{ }^{3} \mathrm{~J}_{\mathrm{CP}}=10 \mathrm{~Hz}\right.$, ipso$\left.C_{5} \mathrm{H}_{4} \mathrm{R}\right), 68.6\left(\mathrm{~s}, \mathrm{C}_{5} \mathrm{H}_{5}\right), 68.1\left(\mathrm{~s}, \alpha-C_{5} \mathrm{H}_{4} \mathrm{R}\right), 67.7\left(\mathrm{~s}, \beta-C_{5} \mathrm{H}_{4} \mathrm{R}\right), 30.6(\mathrm{~d}$, $\left.{ }^{2} J_{\mathrm{CP}}=5 \mathrm{~Hz}, \mathrm{C}_{5} \mathrm{H}_{4} \mathrm{CH}_{2}\right), 23.2\left(\mathrm{~d},{ }^{1} \mathrm{~J}_{\mathrm{CP}}=25 \mathrm{~Hz}, \mathrm{CH}_{2} \mathrm{PH}_{2}\right){ }^{31} \mathrm{P} \mathrm{NMR}\left(\mathrm{CDCl}_{3}\right)$ : $\delta-80.4$ (t of $\mathrm{m},{ }^{1} J_{\mathrm{PH}}=319 \mathrm{~Hz}$ ). FT-IR: $3094(w), 2917(w), 2345(w)$, $2075(\mathrm{~m}), 1993(\mathrm{w}), 1922(\mathrm{~s}), 1644(\mathrm{w}), 1413(\mathrm{w}), 1445(\mathrm{w}), 1105$ $(w), 1089(w), 1000(w), 925(w), 670(w), 607(m) \mathrm{cm}^{-1}$. UV-Vis $\left(\mathrm{CH}_{2} \mathrm{Cl}_{2}\right): \lambda_{\max } 439 \mathrm{~nm}\left(\varepsilon=115 \mathrm{M}^{-1} \mathrm{~cm}^{-1}\right)$. Mass Spec. (El, +ve mode): exact mass calculated for $\left[\mathrm{C}_{17} \mathrm{H}_{15}{ }^{56} \mathrm{Fe}^{92} \mathrm{MoO}_{5} \mathrm{P}\right]^{+}$: 477.9076; exact mass found: 477.9056; difference: $-4.2 \mathrm{ppm}$. Anal. Calcd. (\%) for $\mathrm{C}_{17} \mathrm{H}_{15} \mathrm{FeMoO}_{5} \mathrm{P}: \mathrm{C}, 42.36 ; \mathrm{H}, 3.14$. Found: $\mathrm{C}, 42.45 ; \mathrm{H}, 2.99$.

\section{Secondary phosphine complex $6 \mathrm{~b}(\mathrm{M}=\mathrm{Mo})$}

From $\mathrm{Mo}(\mathrm{CO})_{6}(0.288 \mathrm{~g}, 1.09 \mathrm{mmol}, 5$ equiv.) and phosphine $4 \mathrm{~b}$ $(0.100 \mathrm{~g}, 0.218 \mathrm{mmol})$. Yield $=0.117 \mathrm{~g}, 81 \%$ of orange solid $\left(\mathrm{R}_{\mathrm{f}}=\right.$ 0.20). M.p. $64-66{ }^{\circ} \mathrm{C} .{ }^{1} \mathrm{H} N M R\left(\mathrm{CDCl}_{3}\right): \delta 4.54$ (d of $\mathrm{m},{ }^{1} J_{\mathrm{HP}}=315 \mathrm{~Hz}$, $1 \mathrm{H}, \mathrm{PH}), 4.13\left(\mathrm{~s}, 10 \mathrm{H}, \mathrm{C}_{5} \mathrm{H}_{5}\right), 4.11\left(\mathrm{~s}, 8 \mathrm{H}, \alpha-\mathrm{C}_{5} H_{4} \mathrm{R}\right.$, and $\left.\beta-\mathrm{C}_{5} \mathrm{H}_{4} \mathrm{R}\right), 2.63$ $\left.\left(\mathrm{m}, 4 \mathrm{H}, \mathrm{C}_{5} \mathrm{H}_{4} \mathrm{CH}_{2}\right), 2.05\left(\mathrm{~m}, 4 \mathrm{H}, \mathrm{CH}_{2} \mathrm{PH}\right) .{ }^{13} \mathrm{C}^{1} \mathrm{H}\right\} \mathrm{NMR}\left(\mathrm{CDCl}_{3}\right): \delta 209.2$ $\left(\mathrm{d},{ }^{2} \mathrm{~J}_{\mathrm{CP}}=22 \mathrm{~Hz}\right.$, cis-CO), $205.7\left(\mathrm{~d},{ }^{2} \mathrm{~J}_{\mathrm{CP}}=9 \mathrm{~Hz}\right.$, trans-CO), $87.5\left(\mathrm{~d},{ }^{3} \mathrm{~J}_{\mathrm{CP}}=\right.$ $14 \mathrm{~Hz}$, ipso- $\left.\mathrm{C}_{5} \mathrm{H}_{4} \mathrm{R}\right), 68.6\left(\mathrm{~s}, \mathrm{C}_{5} \mathrm{H}_{5}\right), 67.9\left(\mathrm{~d},{ }^{4} \mathrm{~J}_{\mathrm{CP}}=15 \mathrm{~Hz}, \alpha-\mathrm{C}_{5} \mathrm{H}_{4} \mathrm{R}\right), 67.6$ (s, $\left.\beta-\mathrm{C}_{5} \mathrm{H}_{4} \mathrm{R}\right), 27.6\left(\mathrm{~d},{ }^{1} \mathrm{~J}_{\mathrm{CP}}=22 \mathrm{~Hz}, \mathrm{CH}_{2} \mathrm{PH}\right), 27.0\left(\mathrm{~s}, \mathrm{C}_{5} \mathrm{H}_{4} \mathrm{CH}_{2}\right) .{ }^{31} \mathrm{P} \mathrm{NMR}$ $\left(\mathrm{CDCl}_{3}\right): \delta-22.9\left(\mathrm{~d}\right.$ of $\mathrm{m},{ }^{1} J_{\mathrm{PH}}=315 \mathrm{~Hz}$ ). FT-IR: $3094(\mathrm{w}), 2917(\mathrm{w})$, $2071(\mathrm{~m}), 1986(w), 1925(\mathrm{~s}), 1640(w), 1411(w), 1105(w), 1000$ $(\mathrm{w}), 819(\mathrm{w}), 608(\mathrm{~m}) \mathrm{cm}^{-1}$. UV-Vis $\left(\mathrm{CH}_{2} \mathrm{Cl}_{2}\right): \lambda_{\max } 436 \mathrm{~nm}\left(\varepsilon=250 \mathrm{M}^{-}\right.$ ${ }^{1} \mathrm{~cm}^{-1}$ ). Mass Spec. (El, +ve mode): exact mass calculated for $\left[\mathrm{C}_{29} \mathrm{H}_{27}{ }^{56} \mathrm{Fe}_{2}{ }^{92} \mathrm{MoO}_{5} \mathrm{P}\right]^{+}$: 689.9367; exact mass found: 689.9335; difference: -4.6 ppm. Anal. Calcd. (\%) for $\mathrm{C}_{29} \mathrm{H}_{27} \mathrm{Fe}_{2} \mathrm{MoO}_{5} \mathrm{P}: \mathrm{C}, 50.18$; $H, 3.92$. Found: $C, 50.25 ; H, 3.95$.

\section{Tertiary phosphine complex $6 \mathrm{c}(\mathrm{M}=\mathrm{Mo})$}

From $\mathrm{Mo}(\mathrm{CO})_{6}$ (0.296 g, $1.12 \mathrm{mmol}, 5$ equiv.) and phosphine 4c $(0.150 \mathrm{~g}, 0.224 \mathrm{mmol})$. Yield $=0.159 \mathrm{~g}, 81 \%$ of orange solid $\left(\mathrm{R}_{\mathrm{f}}=\right.$ 0.18). M.p. $75-77^{\circ} \mathrm{C} .{ }^{1} \mathrm{H} N M R\left(\mathrm{CDCl}_{3}\right): \delta 4.20\left(\mathrm{~s}, 15 \mathrm{H}, \mathrm{C}_{5} \mathrm{H}_{5}\right), 4.19(\mathrm{~s}$, $\left.6 \mathrm{H}, \beta-\mathrm{C}_{5} \mathrm{H}_{4} \mathrm{R}\right), 4.18\left(\mathrm{~s}, 6 \mathrm{H}, \alpha-\mathrm{C}_{5} \mathrm{H}_{4} \mathrm{R}\right), 2.61\left(\mathrm{~m}, 6 \mathrm{H}, \mathrm{C}_{5} \mathrm{H}_{4} \mathrm{CH}_{2}\right), 2.06(\mathrm{~m}$, $\left.6 \mathrm{H}, \mathrm{CH}_{2} \mathrm{P}\right) .{ }^{13} \mathrm{C}\left\{{ }^{1} \mathrm{H}\right\}$ NMR $\left(\mathrm{CDCl}_{3}\right): \delta 209.4\left(\mathrm{~d},{ }^{2} J_{\mathrm{CP}}=21 \mathrm{~Hz}\right.$, cis-CO), $206.3\left(\mathrm{~d},{ }^{2} J_{\mathrm{CP}}=9 \mathrm{~Hz}\right.$, trans-CO), $88.0\left(\mathrm{~d},{ }^{3} \mathrm{~J}_{\mathrm{CP}}=15 \mathrm{~Hz}\right.$, ipso- $\left.\mathrm{C}_{5} \mathrm{H}_{4} \mathrm{R}\right), 68.6$ $\left(\mathrm{s}, \mathrm{C}_{5} \mathrm{H}_{5}\right), 67.8\left(\mathrm{~s}, \alpha-\mathrm{C}_{5} \mathrm{H}_{4} \mathrm{R}\right), 67.6\left(\mathrm{~s}, \beta-\mathrm{C}_{5} \mathrm{H}_{4} \mathrm{R}\right), 31.1\left(\mathrm{~d},{ }^{1} \mathrm{~J}_{\mathrm{CP}}=18 \mathrm{~Hz}\right.$, $\left.\mathrm{CH}_{2} \mathrm{P}\right), 24.3\left(\mathrm{~s}, \mathrm{C}_{5} \mathrm{H}_{4} \mathrm{CH}_{2}\right) .{ }^{31} \mathrm{P}$ NMR $\left(\mathrm{CDCl}_{3}\right): \delta 12.5(\mathrm{~m})$. FT-IR: 3094 $(w), 2928(w), 2067(m), 1981(w), 1929(s), 1634(w), 1411(w)$, $1106(w), 1000(w), 818(w), 610(\mathrm{~m}) \mathrm{cm}^{-1}$. UV-Vis $\left(\mathrm{CH}_{2} \mathrm{Cl}_{2}\right): \lambda_{\max } 435$ $\mathrm{nm}\left(\varepsilon=350 \mathrm{M}^{-1} \mathrm{~cm}^{-1}\right)$. Mass Spec. (El, +ve mode): exact mass calculated for $\left[\mathrm{C}_{41} \mathrm{H}_{39}{ }^{56} \mathrm{Fe}_{3}{ }^{98} \mathrm{MoO}_{5} \mathrm{P}\right]^{+}$: 907.9637; exact mass found: 907.9595; difference: -4.6 ppm. Anal. Calcd. (\%) for $\mathrm{C}_{41} \mathrm{H}_{39} \mathrm{Fe}_{3} \mathrm{MoO}_{5} \mathrm{P}: \mathrm{C}, 54.34 ; \mathrm{H}, 4.34$. Found: $\mathrm{C}, 54.40 ; \mathrm{H}, 4.38$.

\section{Primary phosphine complex $7 \mathrm{a}(\mathrm{M}=\mathrm{W})$}

From $\mathrm{W}(\mathrm{CO})_{6}(0.428 \mathrm{~g}, 1.22 \mathrm{mmol}, 5$ equiv.) and phosphine 4a $(0.060 \mathrm{~g}, 0.244 \mathrm{mmol})$. Yield $=0.124 \mathrm{~g}, 89 \%$ of orange solid $\left(\mathrm{R}_{\mathrm{f}}=\right.$ 0.35). M.p. $74-76{ }^{\circ} \mathrm{C} .{ }^{1} \mathrm{H} \mathrm{NMR}\left(\mathrm{CDCl}_{3}\right): \delta 4.55$ (d of m, ${ }^{1} J_{\mathrm{HP}}=332 \mathrm{~Hz}$, $2 \mathrm{H}, \mathrm{PH}$ ), $4.14\left(\mathrm{~s}, 5 \mathrm{H}, \mathrm{C}_{5} \mathrm{H}_{5}\right.$ ), 4.13 (pseudo-t, ${ }^{3} \mathrm{~J}_{\mathrm{HH}}=2 \mathrm{~Hz}, 2 \mathrm{H}, \beta-\mathrm{C}_{5} \mathrm{H}_{4} \mathrm{R}$ ), 4.11 (pseudo-t, $\left.{ }^{3} J_{\mathrm{HH}}=2 \mathrm{~Hz}, 2 \mathrm{H}, \alpha-\mathrm{C}_{5} \mathrm{H}_{4} \mathrm{R}\right), 2.70\left(\mathrm{~m}, 2 \mathrm{H}, \mathrm{C}_{5} \mathrm{H}_{4} \mathrm{CH}_{2}\right), 2.12$ $\left(\mathrm{m}, 2 \mathrm{H}, \mathrm{CH}_{2} \mathrm{PH}_{2}\right) .{ }^{13} \mathrm{C}\left\{{ }^{1} \mathrm{H}\right\} \mathrm{NMR}\left(\mathrm{CDCl}_{3}\right): \delta 198.1\left(\mathrm{~d},{ }^{2} J_{\mathrm{CP}}=22 \mathrm{~Hz}\right.$, cisCO), $195.5\left(\mathrm{~d},{ }^{2} J_{\mathrm{CP}}=7 \mathrm{~Hz}\right.$, trans-CO), $86.6\left(\mathrm{~d},{ }^{3} \mathrm{JP}_{\mathrm{CP}}=12 \mathrm{~Hz}\right.$, ipso- $\left.\mathrm{C}_{5} \mathrm{H}_{4} \mathrm{R}\right)$, $68.7\left(\mathrm{~s}, \mathrm{C}_{5} \mathrm{H}_{5}\right), 68.1\left(\mathrm{~s}, \alpha-\mathrm{C}_{5} \mathrm{H}_{4} \mathrm{R}\right), 67.8\left(\mathrm{~s}, \beta-\mathrm{C}_{5} \mathrm{H}_{4} \mathrm{R}\right), 30.5\left(\mathrm{~d},{ }^{2} J_{\mathrm{CP}}=5 \mathrm{~Hz}\right.$, $\left.\mathrm{C}_{5} \mathrm{H}_{4} \mathrm{CH}_{2}\right), 23.9\left(\mathrm{~d},{ }^{1} \mathrm{~J}_{\mathrm{CP}}=28 \mathrm{~Hz}, \mathrm{CH}_{2} \mathrm{PH}_{2}\right) \cdot{ }^{31} \mathrm{P} \mathrm{NMR}\left(\mathrm{CDCl}_{3}\right): \delta-101.9(\mathrm{t}$ of $\mathrm{m}, 86 \%,{ }^{1} J_{\mathrm{PH}}=333 \mathrm{~Hz}$ ), -101.9 ( $\mathrm{t}$ of $\mathrm{d}$ of $\mathrm{m}, 14 \%,{ }^{1} J_{\mathrm{PH}}=333 \mathrm{~Hz},{ }^{1} J_{\mathrm{PW}}$ $=217$ Hz). FT-IR: 3092 (w), 2917 (w), 2345 (w), $2074(m), 1976(w)$, 
$1912(s), 1638(w), 1439(w), 1411(w), 1318(w), 1105(w), 1089$ (w), $1000(w), 926(w), 884(w), 821(w), 676(w) \mathrm{cm}^{-1}$. UV-Vis $\left(\mathrm{CH}_{2} \mathrm{Cl}_{2}\right): \lambda_{\max } 441 \mathrm{~nm}\left(\varepsilon=120 \mathrm{M}^{-1} \mathrm{~cm}^{-1}\right)$. Mass Spec. (El, +ve mode): exact mass calculated for $\left[\mathrm{C}_{17} \mathrm{H}_{15}{ }^{56} \mathrm{FeO}_{5} \mathrm{P}^{184} \mathrm{~W}\right]^{+}$: 569.9516; exact mass found: 569.9517; difference: $+0.2 \mathrm{ppm}$. Anal. Calcd. (\%) for $\mathrm{C}_{17} \mathrm{H}_{15} \mathrm{FeO}_{5} \mathrm{PW}: \mathrm{C}, 35.82 ; \mathrm{H}, 2.65$. Found: C, 36.06; H, 2.55 .

\section{Secondary phosphine complex $7 \mathrm{~b}(\mathrm{M}=\mathrm{W})$}

From $\mathrm{W}(\mathrm{CO})_{6}(0.384 \mathrm{~g}, 1.09 \mathrm{mmol}, 5$ equiv.) and phosphine $\mathbf{4 b}$ $(0.100 \mathrm{~g}, 0.218 \mathrm{mmol})$. Yield $=0.154 \mathrm{~g}, 90 \%$ of orange solid $\left(R_{\mathrm{f}}=\right.$ 0.22). M.p. $84-86{ }^{\circ} \mathrm{C} .{ }^{1} \mathrm{H}$ NMR $\left(\mathrm{CDCl}_{3}\right): \delta 4.85$ (d of m, ${ }^{1} J_{\mathrm{HP}}=327 \mathrm{~Hz}$, $1 \mathrm{H}, \mathrm{PH}$ ), $4.14\left(\mathrm{~s}, 10 \mathrm{H}, \mathrm{C}_{5} \mathrm{H}_{5}\right.$ ), 4.12 (pseudo-t, ${ }^{3} \mathrm{~J}_{\mathrm{HH}}=2 \mathrm{~Hz}, 8 \mathrm{H}, \alpha-\mathrm{C}_{5} \mathrm{H}_{4} \mathrm{R}$ and $\left.\beta-\mathrm{C}_{5} \mathrm{H}_{4} \mathrm{R}\right), 2.62\left(\mathrm{~m}, 4 \mathrm{H}, \mathrm{C}_{5} \mathrm{H}_{4} \mathrm{CH}_{2}\right), 2.16\left(\mathrm{~m}, 4 \mathrm{H}, \mathrm{CH}_{2} \mathrm{PH}\right) .{ }^{13} \mathrm{C}\left\{{ }^{1} \mathrm{H}\right\}$ NMR $\left(\mathrm{CDCl}_{3}\right): \delta 198.7\left(\mathrm{~d},{ }^{2} J_{\mathrm{CP}}=21 \mathrm{~Hz}\right.$, cis-CO), $196.4\left(\mathrm{~d},{ }^{2} \mathrm{~J}_{\mathrm{CP}}=7 \mathrm{~Hz}\right.$, trans-CO), $87.3\left(\mathrm{~d},{ }^{3} \mathrm{~J}_{\mathrm{CP}}=14 \mathrm{~Hz}\right.$, ipso- $\left.\mathrm{C}_{5} \mathrm{H}_{4} \mathrm{R}\right), 68.7\left(\mathrm{~s}, \mathrm{C}_{5} \mathrm{H}_{5}\right), 67.8(\mathrm{~d}$, $\left.{ }^{4} J_{C P}=17 \mathrm{~Hz}, \alpha-C_{5} \mathrm{H}_{4} \mathrm{R}\right), 67.7\left(\mathrm{~s}, \beta-C_{5} \mathrm{H}_{4} \mathrm{R}\right), 28.1\left(\mathrm{~d},{ }^{1} J_{\mathrm{CP}}=25 \mathrm{~Hz}, \mathrm{CH}_{2} \mathrm{PH}\right)$, $27.1\left(\mathrm{~s}, \mathrm{C}_{5} \mathrm{H}_{4} \mathrm{CH}_{2}\right) .{ }^{31} \mathrm{P}$ NMR $\left(\mathrm{CDCl}_{3}\right): \delta-43.6\left(\mathrm{~d}\right.$ of $\mathrm{m}, 86 \%,{ }^{1} \mathrm{JPH}_{\mathrm{PH}}=328$ $\mathrm{Hz}$ ), $-43.6\left(\mathrm{~d}\right.$ of $\mathrm{d}$ of $\mathrm{m}, 14 \%,{ }^{1} J_{\mathrm{PH}}=328 \mathrm{~Hz},{ }^{1} J_{\mathrm{PW}}=225 \mathrm{~Hz}$ ). FT-IR: $3092(w), 2917(w), 2070(m), 1978(w), 1914(s), 1640(w), 1411$ (w), $1219(w), 1105(w), 1000(w), 820(w), 772(s), 599(w) \mathrm{cm}^{-1}$. UV-Vis $\left(\mathrm{CH}_{2} \mathrm{Cl}_{2}\right): \lambda_{\max } 437 \mathrm{~nm}\left(\varepsilon=245 \mathrm{M}^{-1} \mathrm{~cm}^{-1}\right)$. Mass Spec. (El, +ve mode): exact mass calculated for $\left[\mathrm{C}_{29} \mathrm{H}_{27}{ }^{56} \mathrm{Fe}_{2} \mathrm{O}_{5} \mathrm{P}^{184} \mathrm{~W}\right]^{+}$: 781.9804; exact mass found: 781.9791; difference: -1.7 ppm. Anal. Calcd. (\%) for $\mathrm{C}_{29} \mathrm{H}_{27} \mathrm{Fe}_{2} \mathrm{O}_{5} \mathrm{PW}: \mathrm{C}, 44.54 ; \mathrm{H}, 3.48$. Found: $\mathrm{C}, 44.70 ; \mathrm{H}, 3.44$.

\section{Tertiary phosphine complex $7 \mathrm{c}(\mathrm{M}=\mathrm{W})$}

From $\mathrm{W}(\mathrm{CO})_{6}(0.394 \mathrm{~g}, 1.12 \mathrm{mmol}, 5$ equiv.) and phosphine 4c $(0.150 \mathrm{~g}, 0.224 \mathrm{mmol})$. Yield $=0.194 \mathrm{~g}, 87 \%$ of orange solid $\left(R_{\mathrm{f}}=\right.$ 0.18). M.p. $143-145{ }^{\circ} \mathrm{C} .{ }^{1} \mathrm{H} N M R\left(\mathrm{CDCl}_{3}\right): \delta 4.15\left(\mathrm{~s}, 15 \mathrm{H}, \mathrm{C}_{5} \mathrm{H}_{5}\right), 4.14$ (s, $12 \mathrm{H}, \alpha-\mathrm{C}_{5} \mathrm{H}_{4} \mathrm{R}$ and $\left.\beta-\mathrm{C}_{5} \mathrm{H}_{4} \mathrm{R}\right), 2.56\left(\mathrm{~m}, 6 \mathrm{H}, \mathrm{C}_{5} \mathrm{H}_{4} \mathrm{CH}_{2}\right), 2.11(\mathrm{~m}, 6 \mathrm{H}$, $\left.\mathrm{CH}_{2} \mathrm{P}\right) .{ }^{13} \mathrm{C}\left\{{ }^{1} \mathrm{H}\right\}$ NMR $\left(\mathrm{CDCl}_{3}\right): \delta 198.8\left(\mathrm{~d},{ }^{2} J_{\mathrm{CP}}=21 \mathrm{~Hz}\right.$, cis-CO), 197.2 $\left(\mathrm{d},{ }^{2} J_{\mathrm{CP}}=8 \mathrm{~Hz}\right.$, trans-CO), $87.8\left(\mathrm{~d},{ }^{3} \mathrm{~J}_{\mathrm{CP}}=15 \mathrm{~Hz}\right.$, ipso- $\left.C_{5} \mathrm{H}_{4} \mathrm{R}\right), 68.6(\mathrm{~s}$, $\left.\mathrm{C}_{5} \mathrm{H}_{5}\right), 67.8\left(\mathrm{~s}, \alpha-\mathrm{C}_{5} \mathrm{H}_{4} \mathrm{R}\right), 67.6\left(\mathrm{~s}, \beta-\mathrm{C}_{5} \mathrm{H}_{4} \mathrm{R}\right), 31.6\left(\mathrm{~d},{ }^{1} J_{\mathrm{CP}}=22 \mathrm{~Hz}, \mathrm{CH}_{2} \mathrm{P}\right)$, $24.6\left(\mathrm{~s}, \mathrm{C}_{5} \mathrm{H}_{4} \mathrm{CH}_{2}\right) .{ }^{31} \mathrm{P}$ NMR $\left(\mathrm{CDCl}_{3}\right): \delta-6.8(\mathrm{~m}, 86 \%),-6.8(\mathrm{~d}$ of $\mathrm{m}$, $\left.14 \%,{ }^{1} J_{\mathrm{PW}}=233 \mathrm{~Hz}\right)$. FT-IR: $3090(w), 2924(w), 2066(\mathrm{~m}), 1974(w)$, $1922(s), 1635$ (w), $1411(w), 1415(w), 1442(w), 1321(w), 1230$ $(w), 1105(w), 1000(w), 820(w), 754(w), 601(w) \mathrm{cm}^{-1}$. UV-Vis $\left(\mathrm{CH}_{2} \mathrm{Cl}_{2}\right): \lambda_{\max } 436 \mathrm{~nm}\left(\varepsilon=335 \mathrm{M}^{-1} \mathrm{~cm}^{-1}\right)$. Mass Spec. (El, +ve mode): exact mass calculated for $\left[\mathrm{C}_{41} \mathrm{H}_{39}{ }^{56} \mathrm{Fe}_{3} \mathrm{O}_{5} \mathrm{P}^{184} \mathrm{~W}\right]^{+}$: 994.0093; exact mass found: 994.0095; difference: $+0.2 \mathrm{ppm}$. Anal. Calcd. (\%) for $\mathrm{C}_{41} \mathrm{H}_{39} \mathrm{Fe}_{3} \mathrm{O}_{5} \mathrm{PW}: \mathrm{C}, 49.54 ; \mathrm{H}, 3.95$. Found: $\mathrm{C}, 50.07 ; \mathrm{H}, 4.03$.

\section{Acknowledgements}

We would like to thank the University of Western Ontario, the Natural Science and Engineering Research Council (NSERC) of Canada (P.J.R., J.B.G.: DG, 311921, 435675), and the Ontario Ministry of Research and Innovation (J.B.G.: ERA, ER14-10-147) for funding this work. We also thank Cytec Canada Inc. for providing phosphine gas and expertise surrounding its safe usage. Finally, we acknowledge Dr. Paul D. Boyle and Stephanie M. Barbon for X-ray crystallography.

\section{Notes and references}

1 Selected examples: (a) B. L. Ghent, L. A. Sites, A. L. Rheingold and C. Nataro, Organometallics, 2005, 24, 4788-4792; (b) R.
Kalio, P. Lönnecke and E. Hey-Hawkins, J. Organomet. Chem., 2008, 693, 590-600; (c) C.-G. Chen, X.-L. Hou and L. Pu, Org. Lett., 2009, 11, 2073-2075; (d) A. Zirakzadeh, R. Schuecker, N. Gorgas, K. Mereiter, F. Spindler and W. Weissensteiner, Organometallics, 2012, 31, 4241-4250; (e) C. B. Khadka, B. K. Najafabadi, M. Hesari, M. S. Workentin and J. F. Corrigan, Inorg. Chem., 2013, 52, 6798-6805; (f) B. E. Cowie, F. A. Tsao and D. J. H. Emslie, Angew. Chem. Int. Ed., 2015, 54, 2165-2169.

2 Selected books and reviews: (a) G. Erre, S. Enthaler, K. Junge, S. Gladiali and M. Beller, Coord. Chem. Rev., 2008, 252, 471-491; (b) K. H. Shaughnessy, Chem. Rev., 2009, 109, 643-710; (c) Phosphorus(III) Ligands in Homogeneous Catalysis: Design and Synthesis, Wiley-Blackwell, Oxford, 2012; (d) S. H. Chikkali, J. I. van der Vlugt and J. N. H. Reek, Coord. Chem. Rev., 2014, 262, 1-15; (e) B. P. Nell and D. R. Tyler, Coord. Chem. Rev., 2014, 279, 23-42.

3 Selected examples: (a) S. P. Annen, V. Bambagioni, M. Bevilacqua, J. Filippi, A. Marchionni, W. Oberhauser, H. Schönberg, F. Vizza, C. Bianchini and H. Grützmacher, Angew. Chem. Int. Ed., 2010, 49, 7229-7233; (b) J. S. Anderson, J. Rittle and J. C. Peters, Nature, 2013, 501, 84-87; (c) P. Kang, S. Zhang, T. J. Meyer and M. Brookhart, Angew. Chem. Int. Ed., 2014, 53, 8709-8713; (d) K. T. Horak, A. Velian, M. W. Day and T. Agapie, Chem. Commun., 2014, 50, 4427-4429; (e) B. J. Johnson, S. V. Lindeman and N. P. Mankad, Inorg. Chem., 2014, 53, 1061110619; (f) H. Tinnermann, C. Wille and M. Alcarazo, Angew. Chem. Int. Ed., 2014, 53, 8732-8736; (g) X. Yan, T. R. Cook, P. Wang, F. Huang and P. J. Stang, Nat. Chem., 2015, 7, 342-348; (h) D. Zhao, T. M. Neubauer and B. L. Feringa, Nat. Commun., 2015, 6; (i) E. L. Hazeland, A. M. Chapman, P. G. Pringle and H. A. Sparkes, Chem. Commun., 2015, 51, 10206-10209.

4 C. A. Tolman, Chem. Rev., 1977, 77, 313-348.

5 M. L. Clarke and J. J. R. Frew, in Organometallic Chemistry: Volume 35, eds. I. J. S. Fairlamb and J. M. Lynam, The Royal Society of Chemistry, Cambridge, 2009, pp. 19-46.

6 Selected examples: (a) A. Staubitz, A. P. Soto and I. Manners, Angew. Chem. Int. Ed., 2008, 47, 6212-6215; (b) E. PiedraArroni, C. Ladavière, A. Amgoune and D. Bourissou, J. Am. Chem. Soc., 2013, 135, 13306-13309; (c) A. Nakamura, T. M. J. Anselment, J. Claverie, B. Goodall, R. F. Jordan, S. Mecking, B. Rieger, A. Sen, P. W. N. M. van Leeuwen and K. Nozaki, Acc. Chem. Res., 2013, 46, 1438-1449; (d) H.-K. Lee, K.-T. Bang, A. Hess, R. H. Grubbs and T.-L. Choi, J. Am. Chem. Soc., 2015, 137, 9262-9265; (e) E. Bultz, M. Ouchi, K. Nishizawa, M. F. Cunningham and M. Sawamoto, ACS Macro Lett., 2015, 4, 628631.

7 Selected examples: (a) G. E. Dobereiner, J. Yuan, R. R. Schrock, A. S. Goldman and J. D. Hackenberg, J. Am. Chem. Soc., 2013, 135, 12572-12575; (b) C. Cheng and J. F. Hartwig, J. Am. Chem. Soc., 2014, 136, 12064-12072; (c) A. Borzenko, N. L. Rotta-Loria, P. M. MacQueen, C. M. Lavoie, R. McDonald and M. Stradiotto, Angew. Chem. Int. Ed., 2015, 54, 3773-3777; (d) E. J. Tollefson, L. E. Hanna and E. R. Jarvo, Acc. Chem. Res., 2015, 48, 23442353; (e) Y. Yang, S.-L. Shi, D. Niu, P. Liu and S. L. Buchwald, Science, 2015, 349, 62-66; (f) S. A. Tymonko, R. C. Smith, A. Ambrosi, M. H. Ober, H. Wang and S. E. Denmark, J. Am. Chem. Soc., 2015, 137, 6200-6218. 
8 Selected examples: (a) M. R. Friedfeld, G. W. Margulieux, B. A. Schaefer and P. J. Chirik, J. Am. Chem. Soc., 2014, 136, 1317813181; (b) T. Zell, Y. Ben-David and D. Milstein, Angew. Chem. Int. Ed., 2014, 53, 4685-4689; (c) A. Zirakzadeh, M. A. Groß, Y. Wang, K. Mereiter and W. Weissensteiner, Organometallics, 2014, 33, 1945-1952; (d) C. Guo, D.-W. Sun, S. Yang, S.-J. Mao, X.-H. Xu, S.-F. Zhu and Q.-L. Zhou, J. Am. Chem. Soc., 2015, 137, 90-93; (e) S. Wesselbaum, V. Moha, M. Meuresch, S. Brosinski, K. M. Thenert, J. Kothe, T. vom Stein, U. Englert, M. Hölscher, J. Klankermayer and W. Leitner, Chem. Sci., 2015, 6, 693-704; (f) W. Zuo and R. H. Morris, Nat. Protoc., 2015, 10, 241-257.

9 Selected Reviews: (a) M. Brynda, Coord. Chem. Rev., 2005, 249, 2013-2034; (b) J. T. Fleming and L. J. Higham, Coord. Chem. Rev., 2015, 297-298, 127-145.

10 Selected examples: (a) G. Ramakrishnan, A. Jouaiti, M. Geoffroy and G. Bernardinelli, J. Phys. Chem., 1996, 100, 10861-10868; (b) K. R. Prabhu, N. Pillarsetty, H. Gali and K. V. Katti, J. Am. Chem. Soc., 2000, 122, 1554-1555; (c) W. Henderson and S. R. Alley, J. Organomet. Chem., 2002, 656, 120-128; (d) R. M. Hiney, L. J. Higham, H. Müller-Bunz and D. G. Gilheany, Angew. Chem. Int. Ed., 2006, 45, 7248-7251; (e) T. E. Barder and S. L. Buchwald, J. Am. Chem. Soc., 2007, 129, 5096-5101; (f) B. Stewart, A. Harriman and L. J. Higham, Organometallics, 2011, 30, 5338-5343; (g) L. H. Davies, B. Stewart, R. W. Harrington, W. Clegg and L. J. Higham, Angew. Chem. Int. Ed., 2012, 51, 49214924; (h) T. Asamizu, W. Henderson, B. K. Nicholson and E. HeyHawkins, Inorg. Chim. Acta, 2014, 414, 181-190.

11 (a) A. Rabiee Kenaree, B. M. Berven, P. J. Ragogna and J. B. Gilroy, Chem. Commun., 2014, 50, 10714-10717; (b) A. Rabiee Kenaree, T. J. Cuthbert, S. M. Barbon, P. D. Boyle, E. R. Gillies, P. J. Ragogna and J. B. Gilroy, Organometallics, 2015, 34, 42724280 .
12 R. Guterman, A. Rabiee Kenaree, J. B. Gilroy, E. R. Gillies and P. J. Ragogna, Chem. Mater., 2015, 27, 1412-1419.

13 R. Guterman, E. R. Gillies and P. J. Ragogna, Dalton Trans., 2015, 44, 15664-15670.

14 Selected examples: (a) A. Labande, J. Ruiz and D. Astruc, J. Am. Chem. Soc., 2002, 124, 1782-1789; (b) R. L. Stiles, R. Balasubramanian, S. W. Feldberg and R. W. Murray, J. Am. Chem. Soc., 2008, 130, 1856-1865; (c) K. A. Mahmoud, S. Hrapovic and J. H. T. Luong, ACS Nano, 2008, 2, 1051-1057; (d) R. C. Mulrooney, N. Singh, N. Kaur and J. F. Callan, Chem. Commun., 2009, 686-688; (e) M. Aminur Rahman, J. Ik Son, M.S. Won and Y.-B. Shim, Anal. Chem., 2009, 81, 6604-6611; (f) Y. Liu, B. Khalili Najafabadi, M. Azizpoor Fard and J. F. Corrigan, Angew. Chem. Int. Ed., 2015, 54, 4832-4835.

15 S. O. Grim, P. R. McAllister and R. M. Singer, Chem. Commun., 1969, 38-39.

16 (a) L. E. Orgel, Inorg. Chem., 1962, 1, 25-29; (b) F. A. Cotton and C. S. Kraihanzel, J. Am. Chem. Soc., 1962, 84, 4432-4438.

17 J. Dalton, I. Paul, J. G. Smith and F. G. A. Stone, J. Chem. Soc. A, 1968, 1195-1199.

18 Bruker-AXS, SAINT version 2013.8, 2013, Bruker-AXS, Madison, WI 53711, USA.

19 Bruker-AXS, SADABS version 2012.1, 2012, Bruker-AXS, Madison, WI 53711, USA.

20 Bruker-AXS, TWINABS version 2012.1, 2012, Bruker-AXS, Madison, WI 53711, USA.

21 GNU Octave https://www.gnu.org/software/octave/ version 3.6.4.

22 G. Sheldrick, Acta Crystallogr., 2015, A71, 3-8.

23 G. Sheldrick, Acta Crystallogr., 2008, A64, 112-122. 


\title{
Supplementary Information
}

\section{Group 6 Metal Pentacarbonyl Complexes of Air-Stable Primary, Secondary, and Tertiary Ferrocenylethylphosphines}

\author{
Amir Rabiee Kenaree, Ethan R. Sauvé, Paul J. Ragogna, Joe B. Gilroy* \\ Department of Chemistry and the Centre for Advanced Materials and Biomaterials Research \\ (CAMBR), The University of Western Ontario, 1151 Richmond St. N., London, Ontario, \\ Canada, N6A 5B7. Tel: +1-519-661-2111 ext. 81561, E-mail: joe.gilroy@uwo.ca.
}

\section{Table of Contents}

NMR Spectra

Solid-State Structures $\mathrm{S} 18$

FT-IR Absorption Spectra. S19

UV-Vis Absorption Spectra. S24

Cyclic Voltammograms

S27 


\section{NMR Spectra}

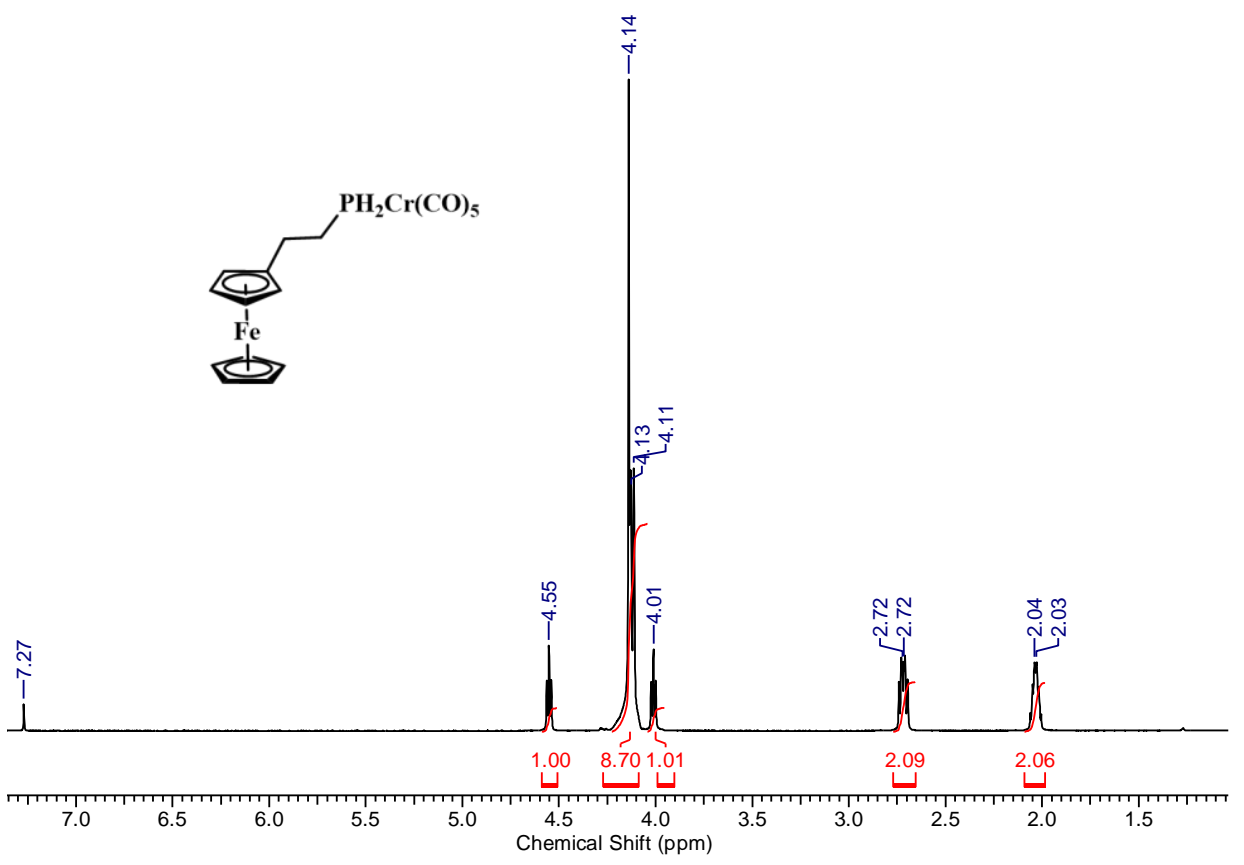

Fig. S1 ${ }^{1} \mathrm{H}$ NMR spectrum of $\mathbf{5 a}$ in $\mathrm{CDCl}_{3}$.

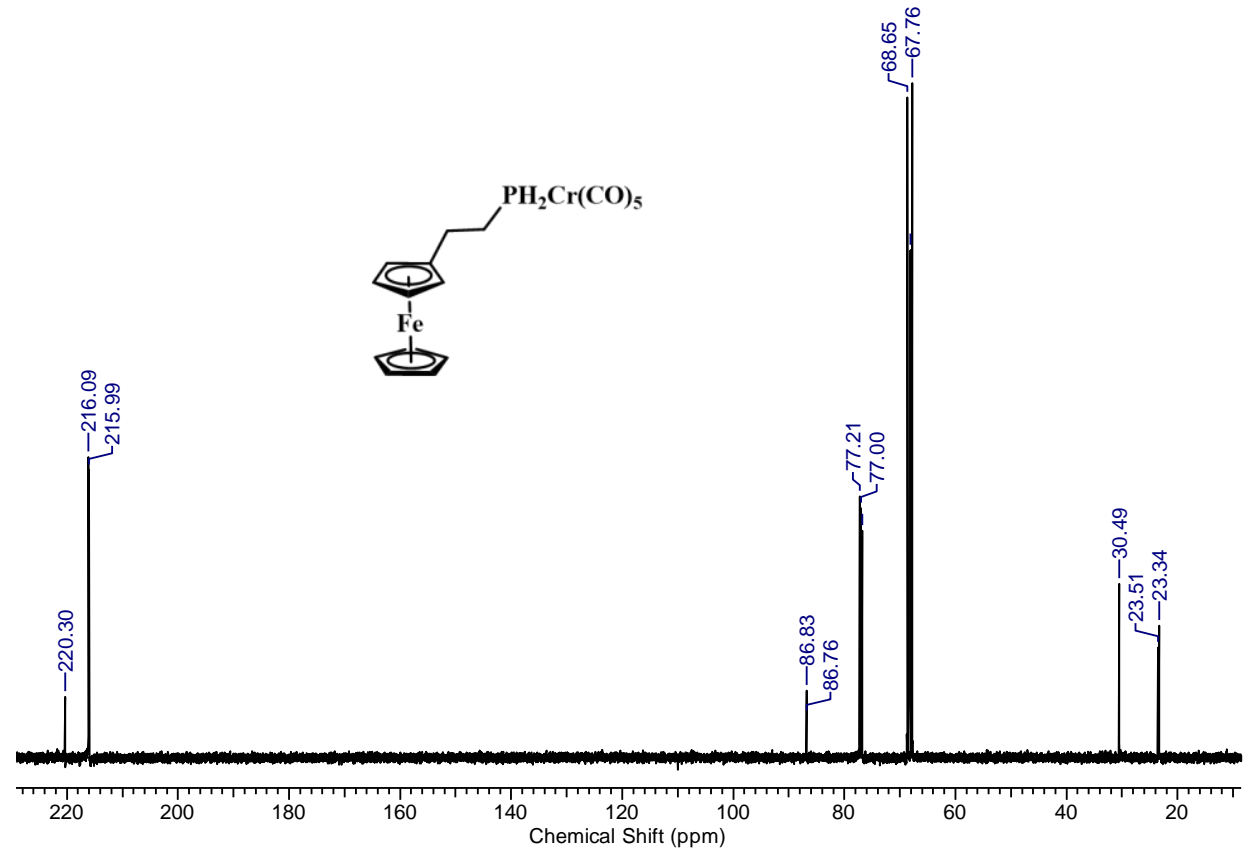

Fig. S2 ${ }^{13} \mathrm{C}\left\{{ }^{1} \mathrm{H}\right\}$ NMR spectrum of $\mathbf{5 a}$ in $\mathrm{CDCl}_{3}$. 


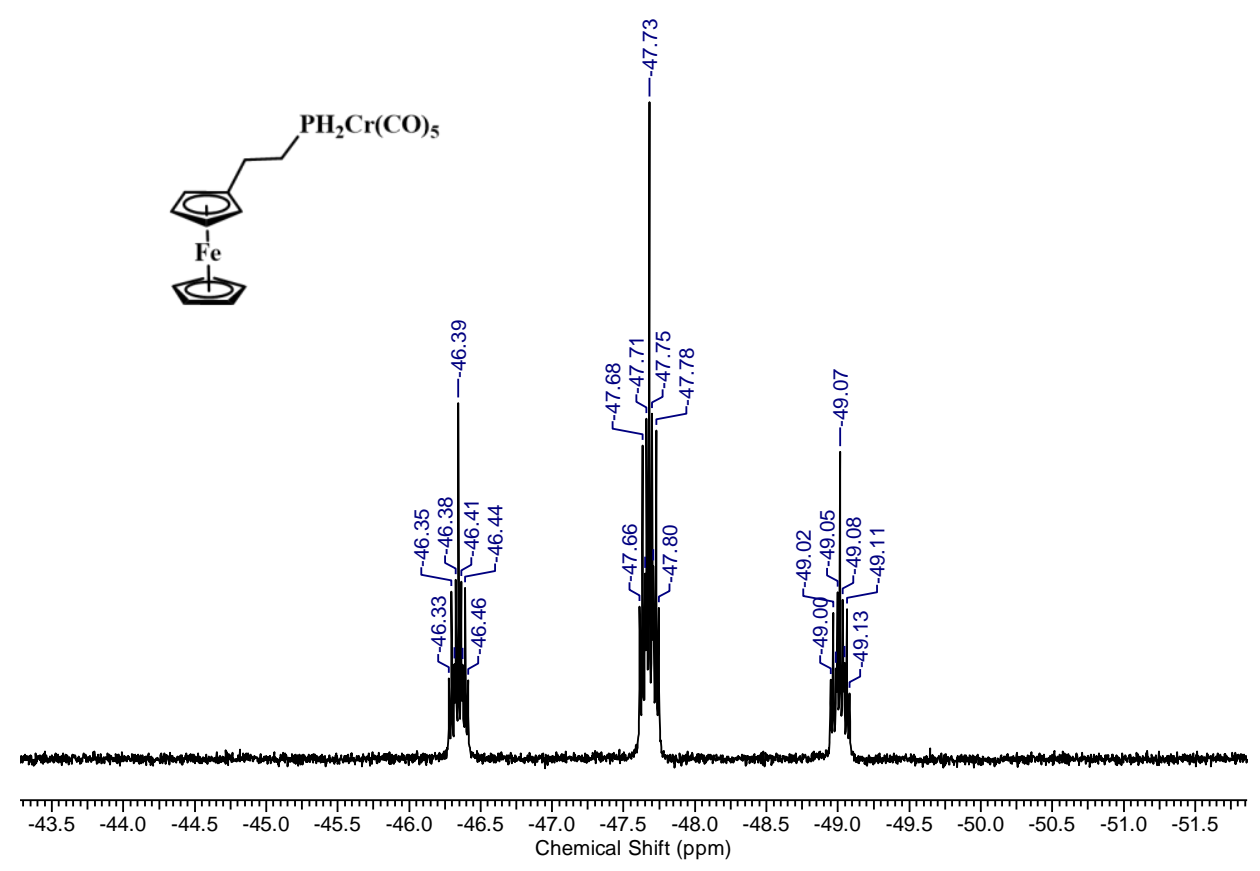

Fig. S3 ${ }^{31} \mathrm{P}$ NMR spectrum of $\mathbf{5 a}$ in $\mathrm{CDCl}_{3}$.

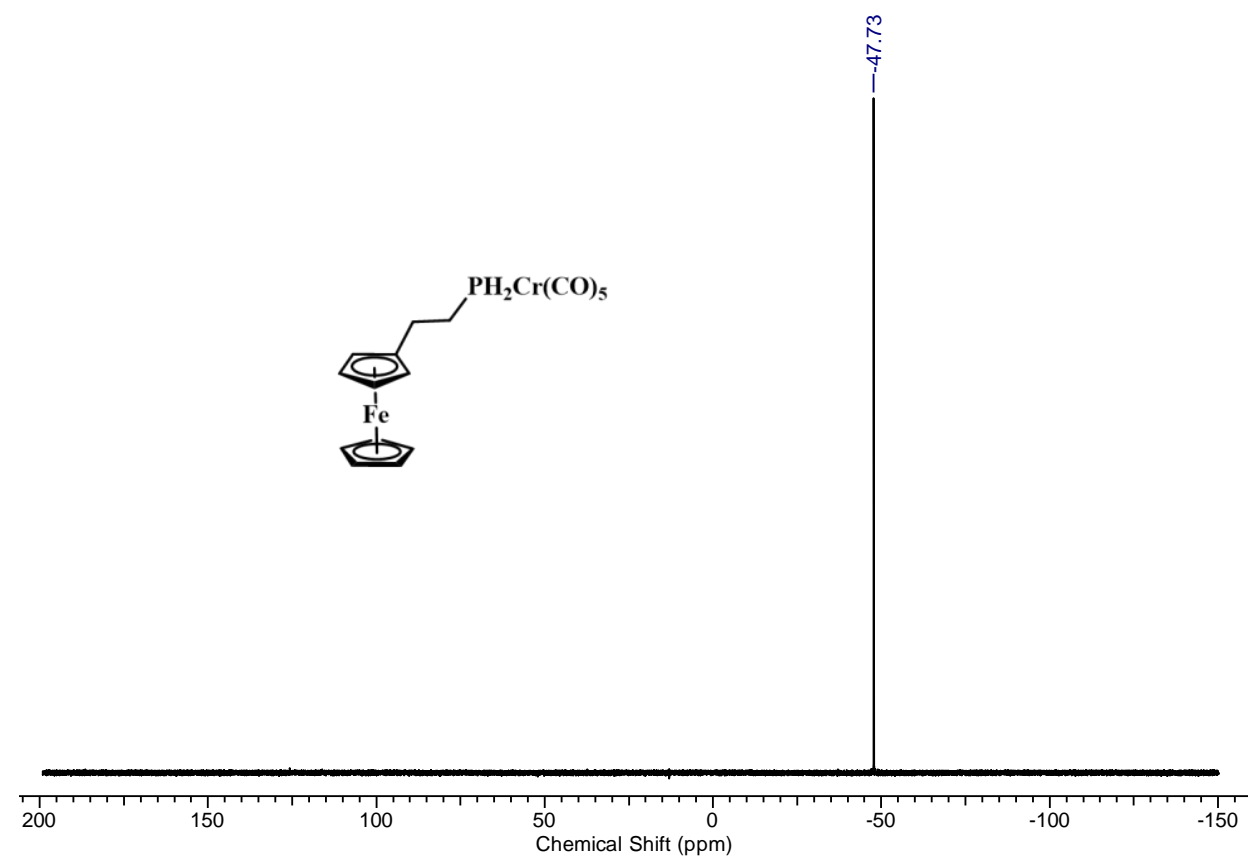

Fig. S4 ${ }^{31} \mathrm{P}\left\{{ }^{1} \mathrm{H}\right\}$ NMR spectrum of $\mathbf{5 a}$ in $\mathrm{CDCl}_{3}$. 


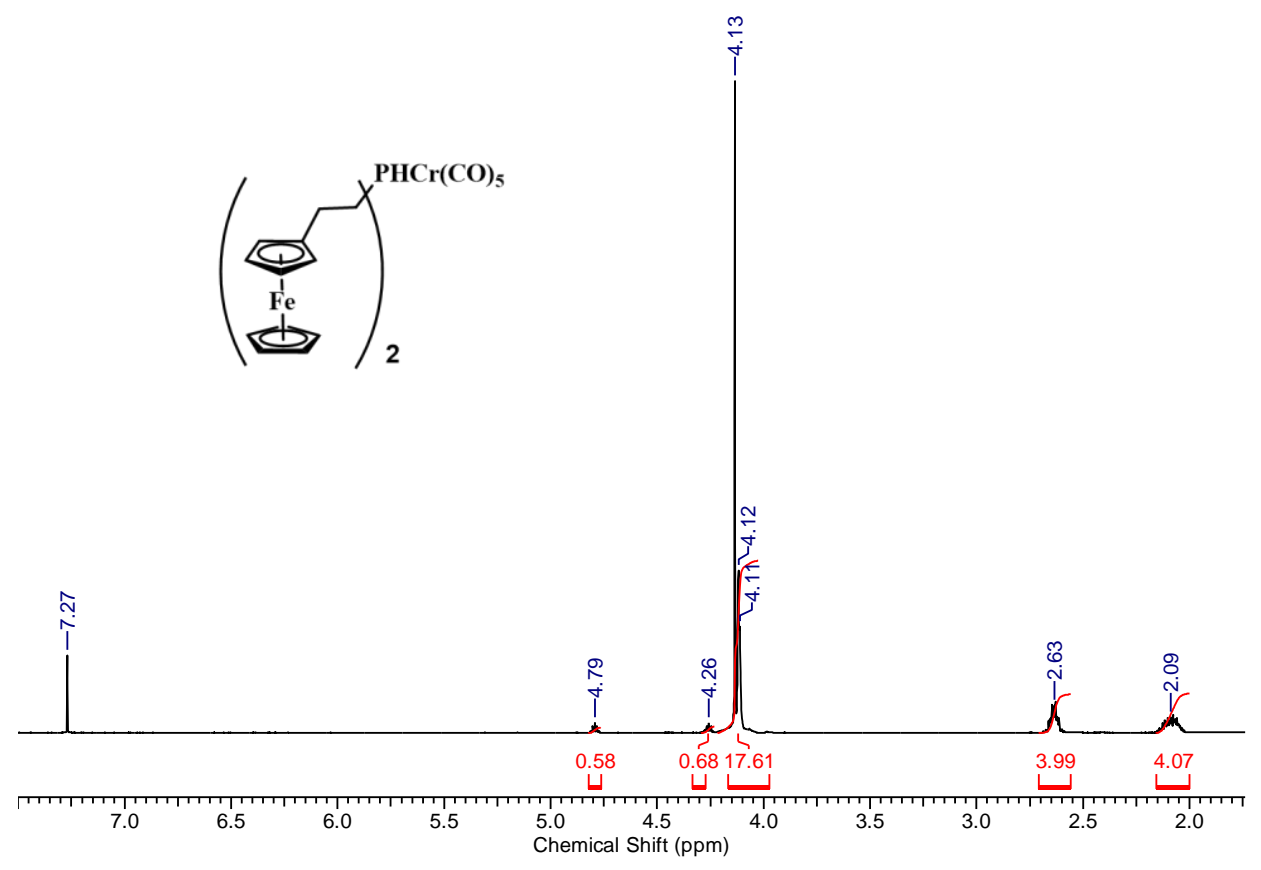

Fig. S5 ${ }^{1} \mathrm{H}$ NMR spectrum of $\mathbf{5 b}$ in $\mathrm{CDCl}_{3}$.

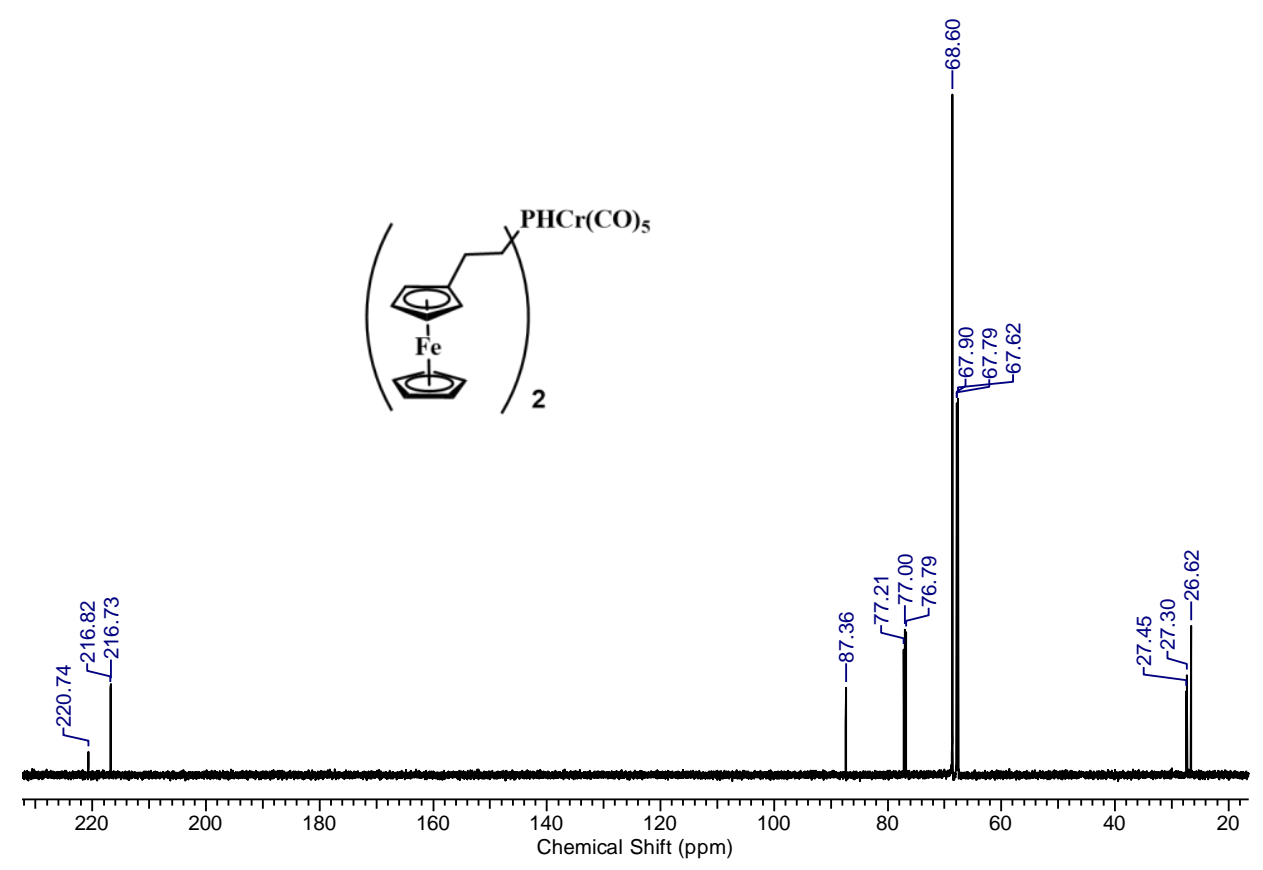

Fig. S6 ${ }^{13} \mathrm{C}\left\{{ }^{1} \mathrm{H}\right\}$ NMR spectrum of $\mathbf{5 b}$ in $\mathrm{CDCl}_{3}$. 


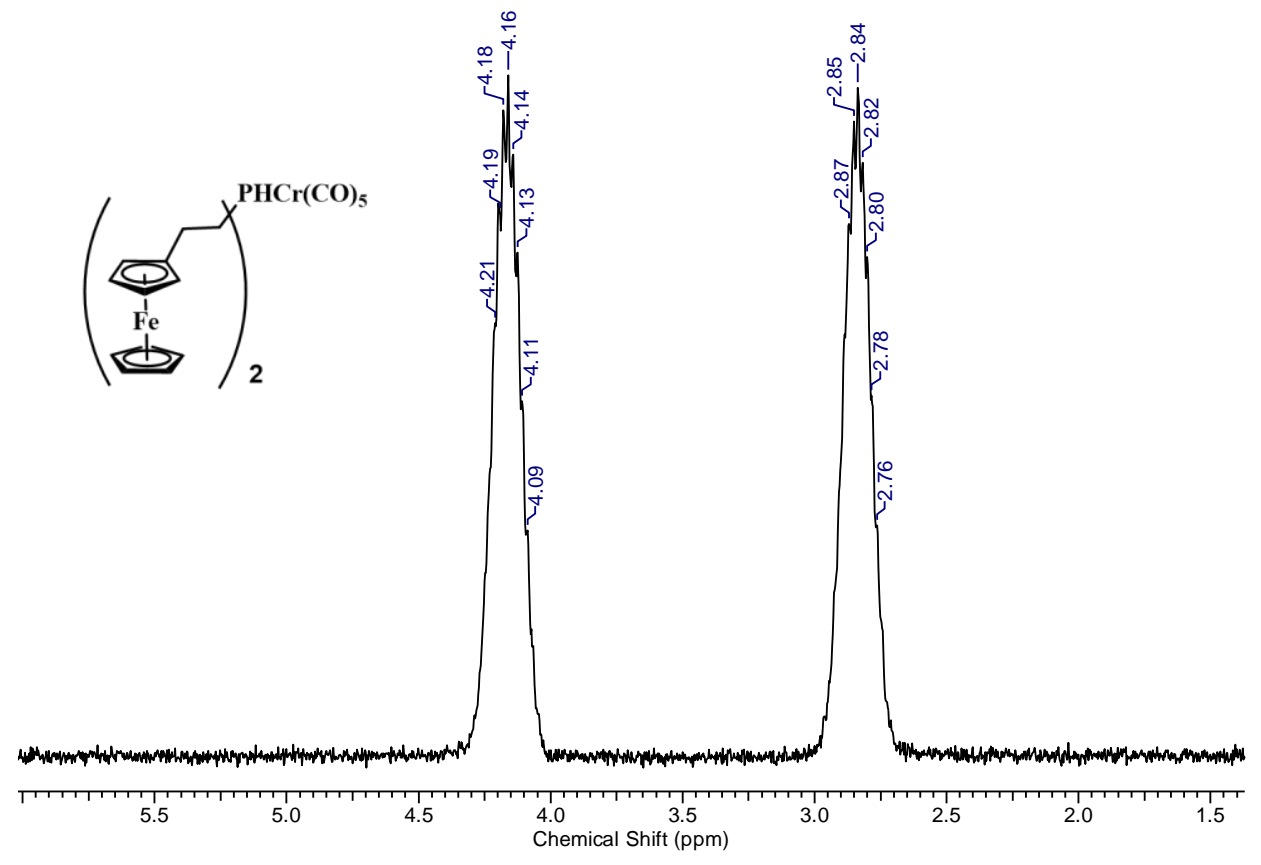

Fig. $\mathbf{S 7}{ }^{31} \mathrm{P}$ NMR spectrum of $\mathbf{5 b}$ in $\mathrm{CDCl}_{3}$.

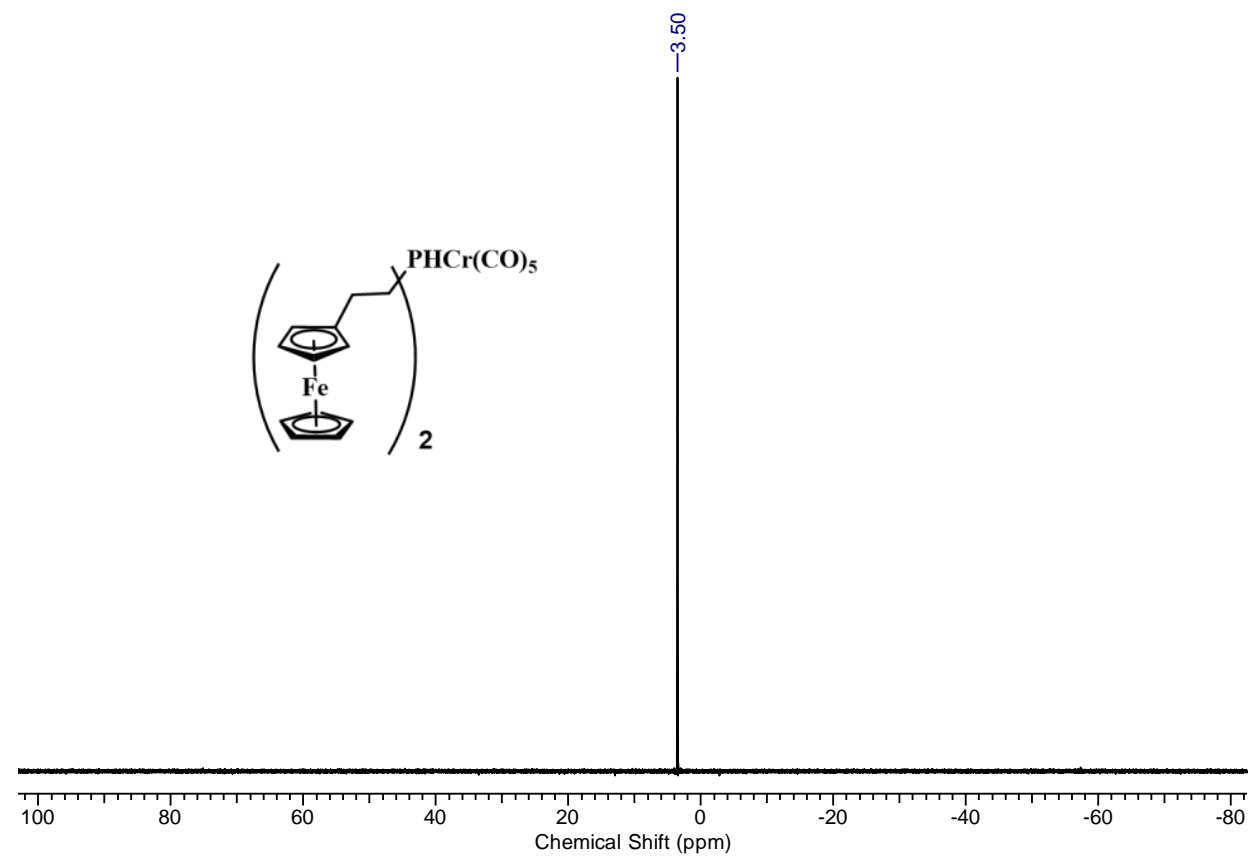

Fig. S8 ${ }^{31} \mathrm{P}\left\{{ }^{1} \mathrm{H}\right\}$ NMR spectrum of $\mathbf{5 b}$ in $\mathrm{CDCl}_{3}$. 


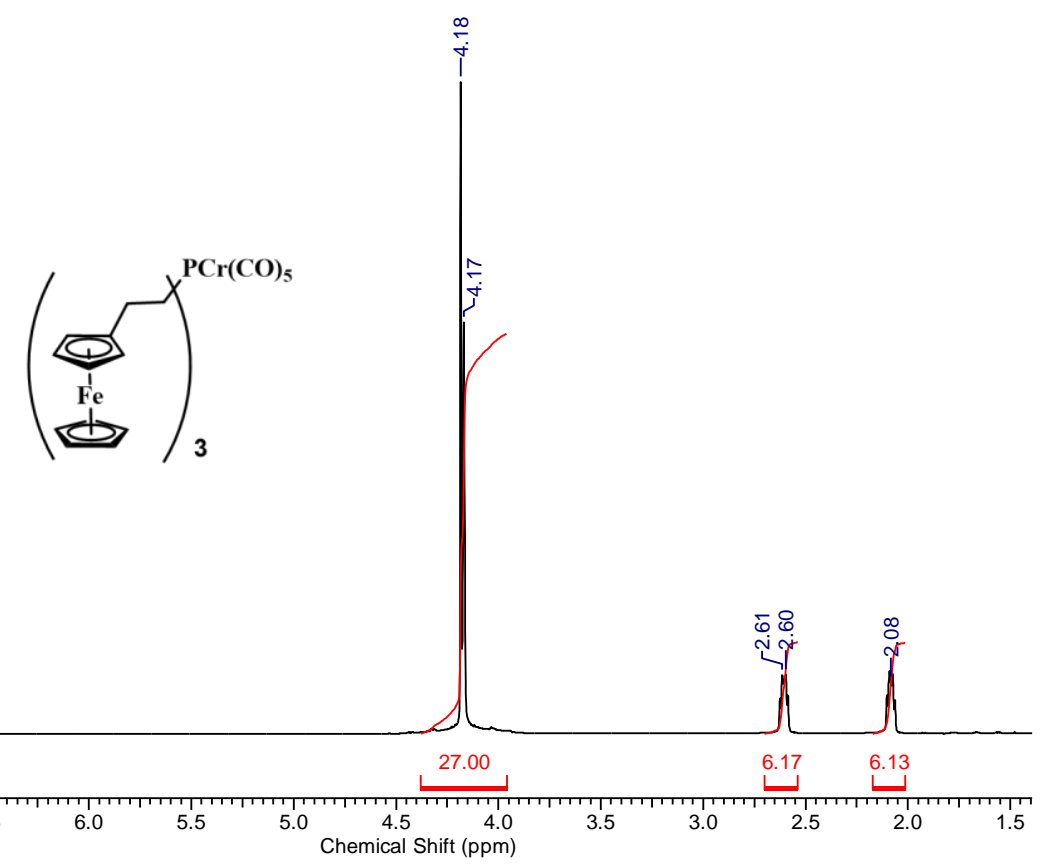

Fig. S9 ${ }^{1} \mathrm{H}$ NMR spectrum of $\mathbf{5 c}$ in $\mathrm{CDCl}_{3}$.
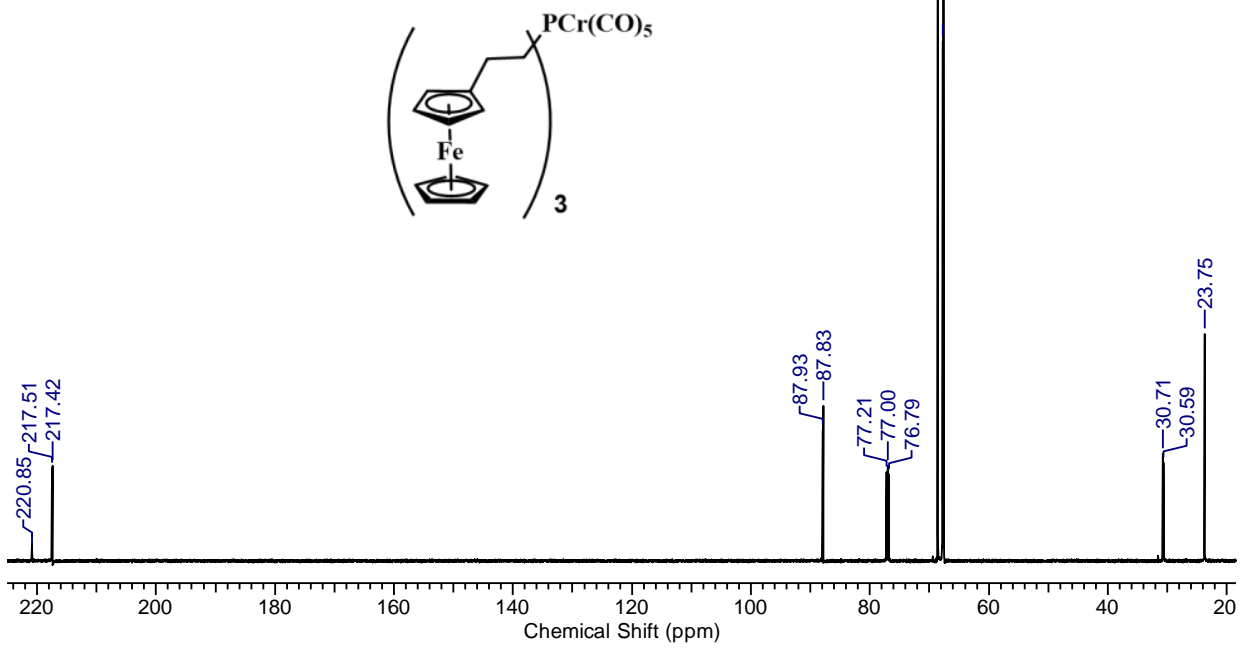

Fig. S10 ${ }^{13} \mathrm{C}\left\{{ }^{1} \mathrm{H}\right\}$ NMR spectrum of $\mathbf{5 c}$ in $\mathrm{CDCl}_{3}$. 


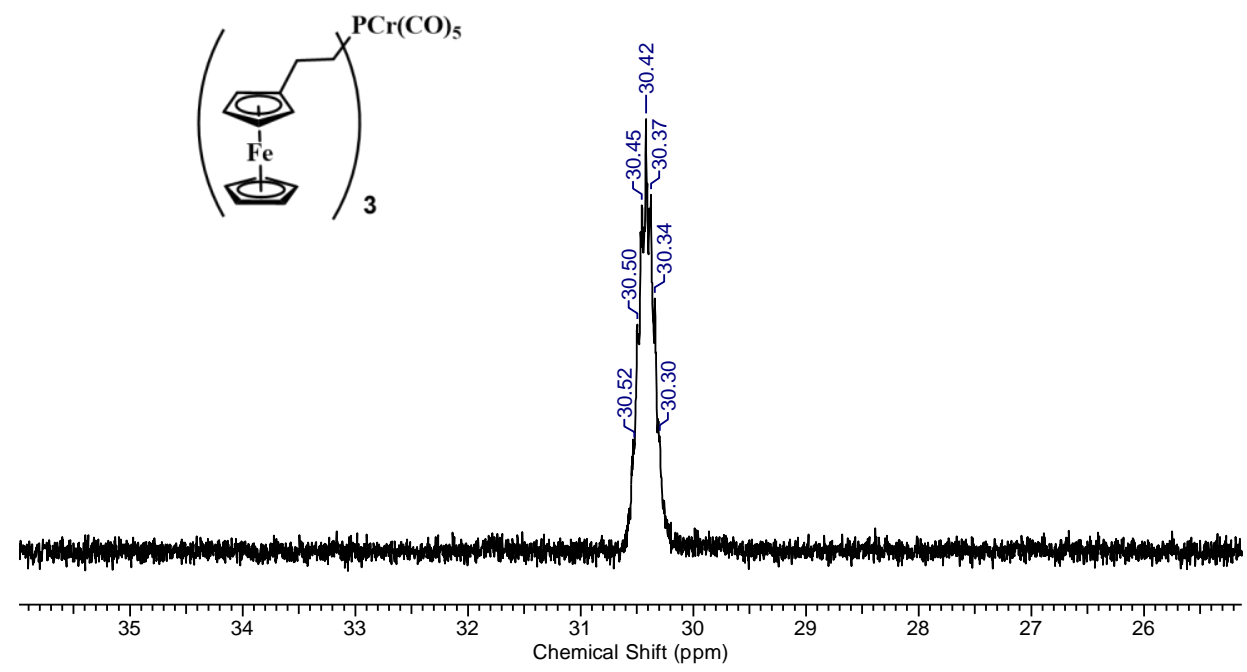

Fig. S11 ${ }^{31} \mathrm{P}$ NMR spectrum of $\mathbf{5 c}$ in $\mathrm{CDCl}_{3}$.

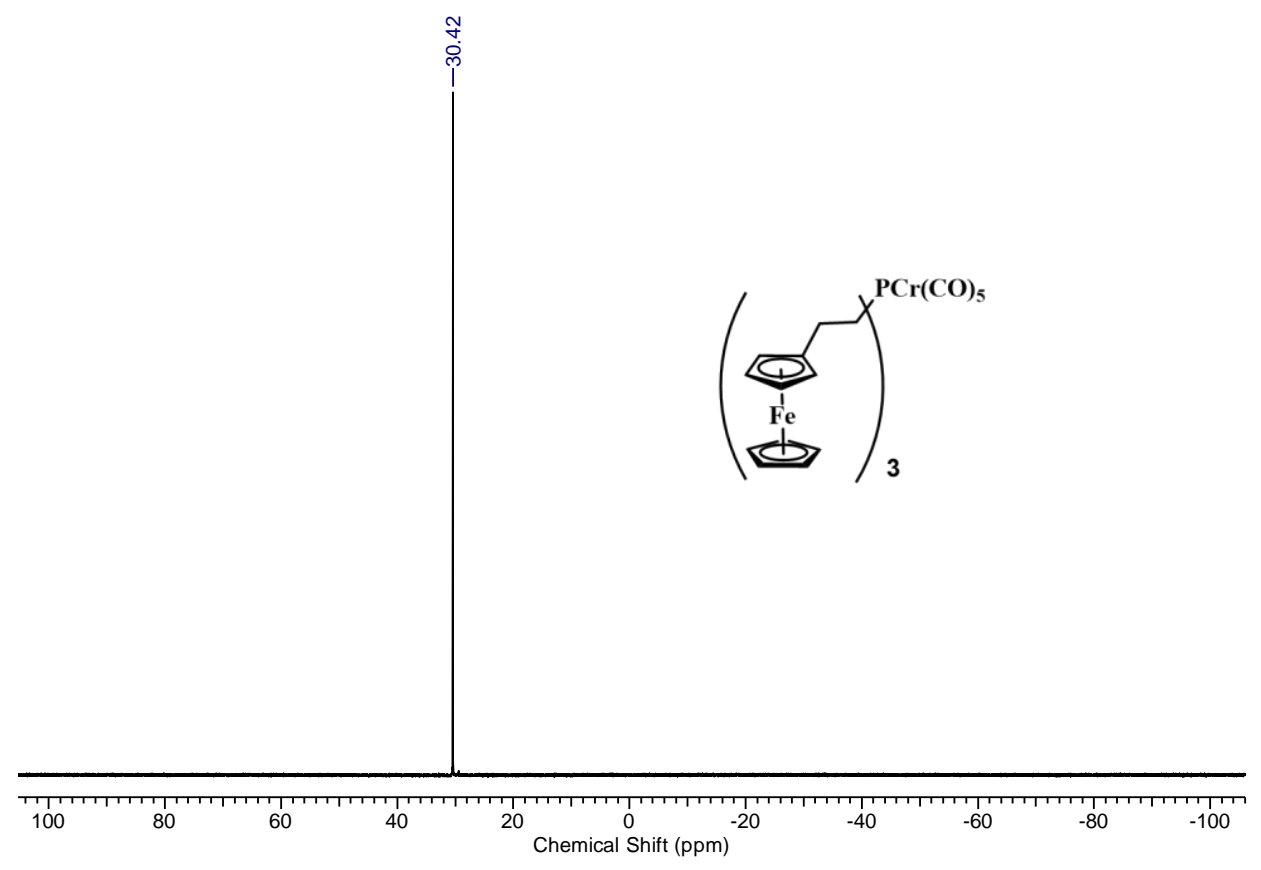

Fig. S12 ${ }^{31} \mathrm{P}\left\{{ }^{1} \mathrm{H}\right\}$ NMR spectrum of $\mathbf{5 c}$ in $\mathrm{CDCl}_{3}$. 


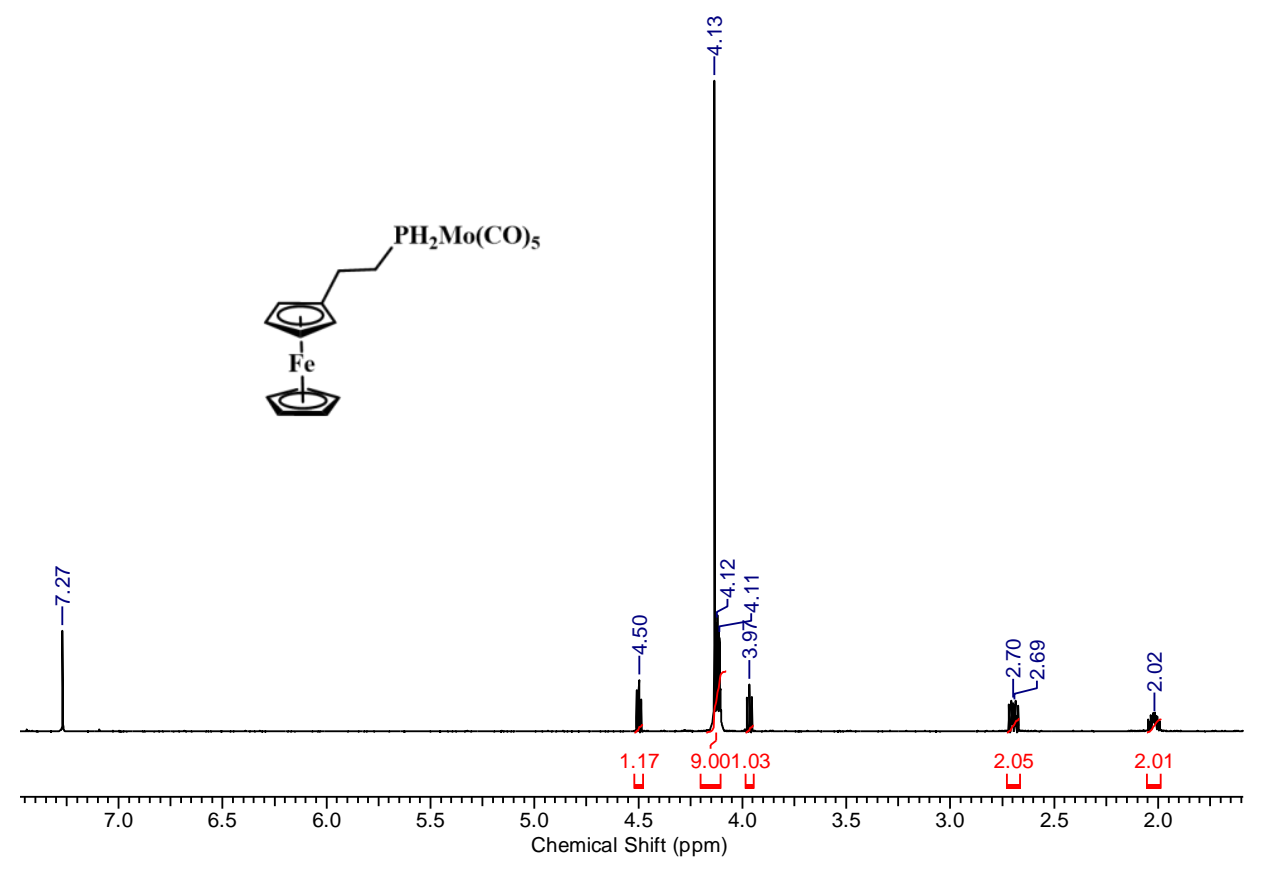

Fig. S13 ${ }^{1} \mathrm{H}$ NMR spectrum of $\mathbf{6 a}$ in $\mathrm{CDCl}_{3}$.

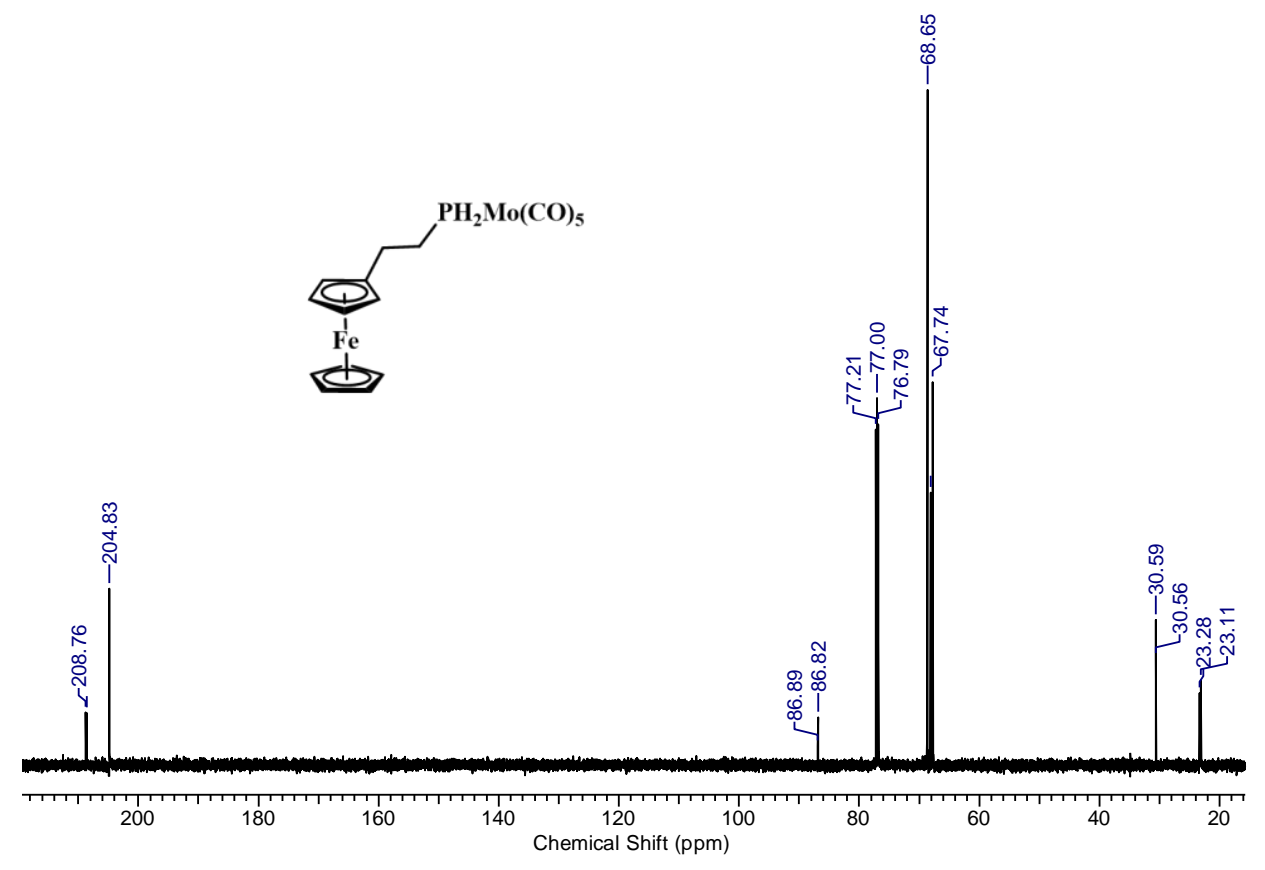

Fig. S14 ${ }^{13} \mathrm{C}\left\{{ }^{1} \mathrm{H}\right\}$ NMR spectrum of $\mathbf{6 a}$ in $\mathrm{CDCl}_{3}$. 


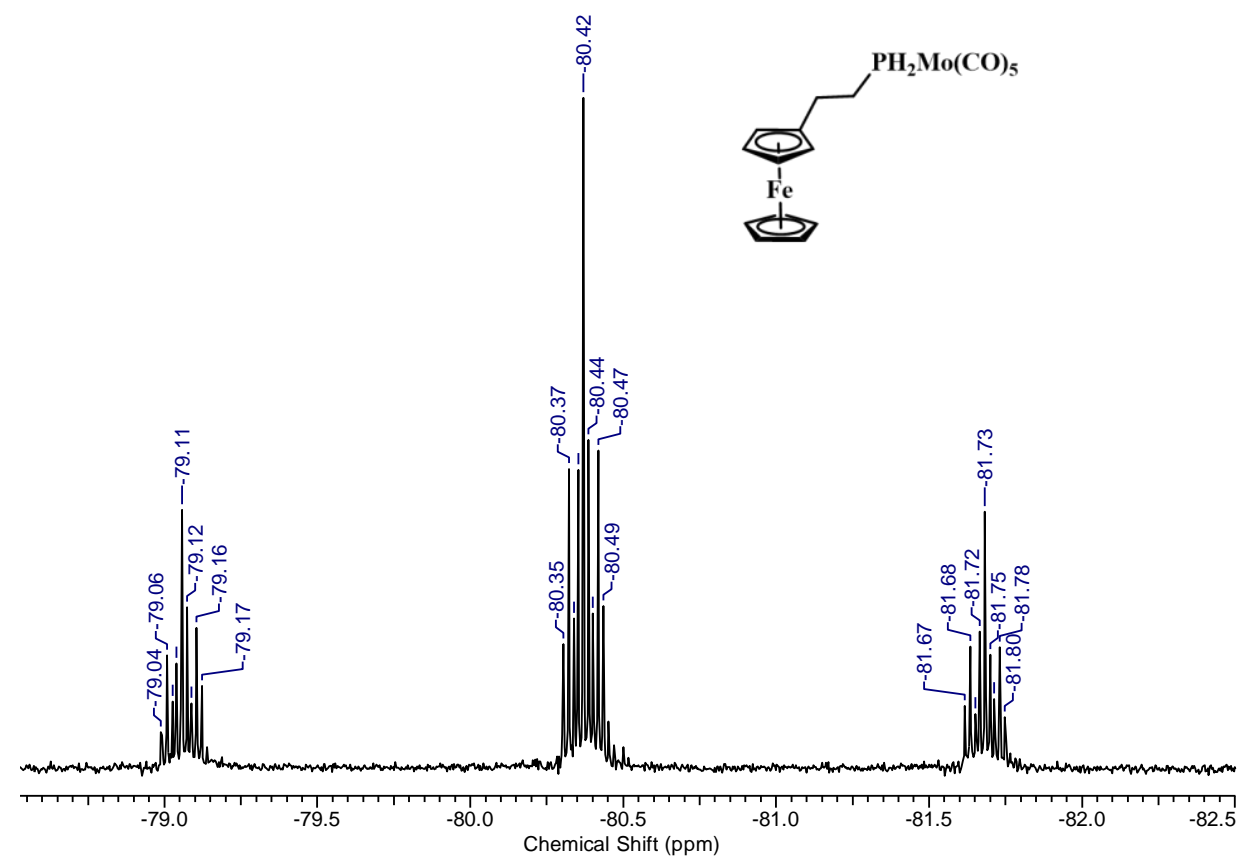

Fig. S15 ${ }^{31} \mathrm{P}$ NMR spectrum of $\mathbf{6 a}$ in $\mathrm{CDCl}_{3}$.

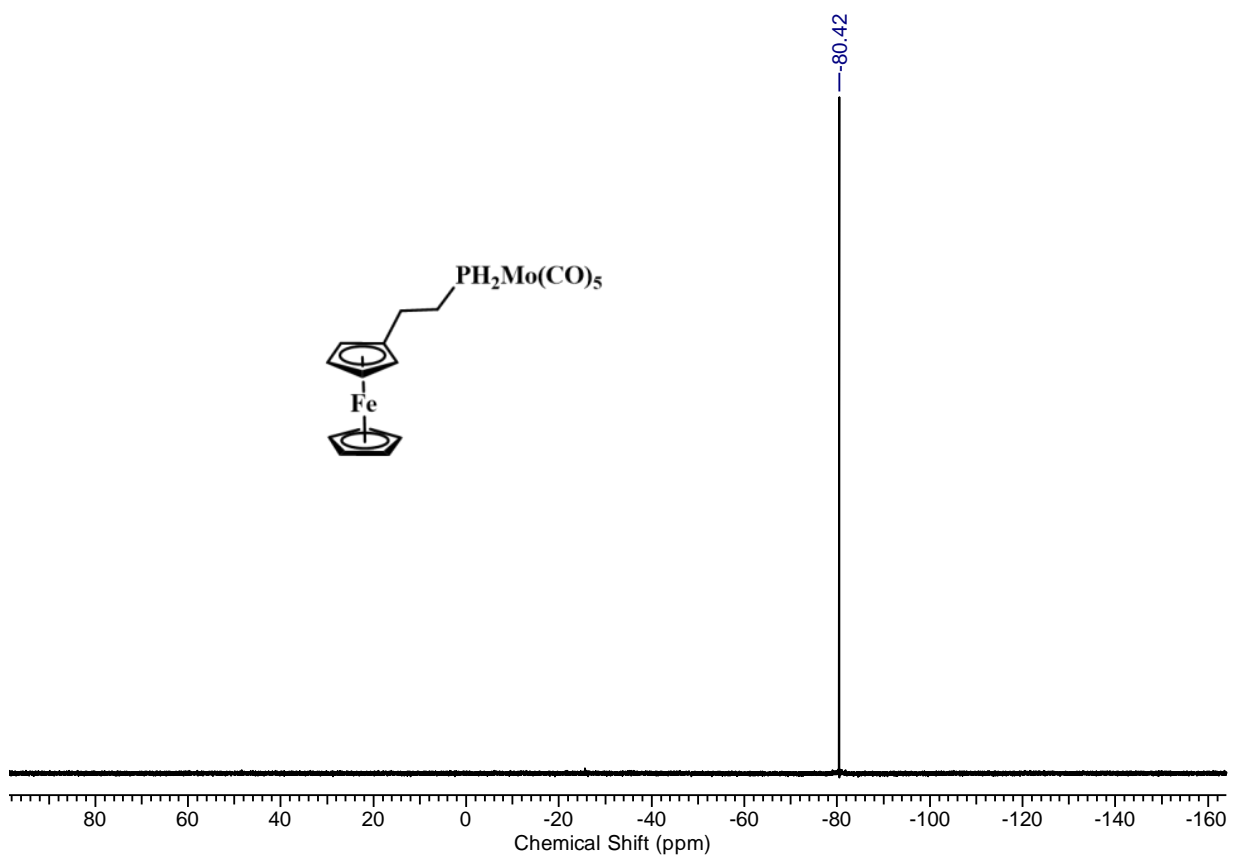

Fig. S16 ${ }^{31} \mathrm{P}\left\{{ }^{1} \mathrm{H}\right\}$ NMR spectrum of $\mathbf{6 a}$ in $\mathrm{CDCl}_{3}$. 


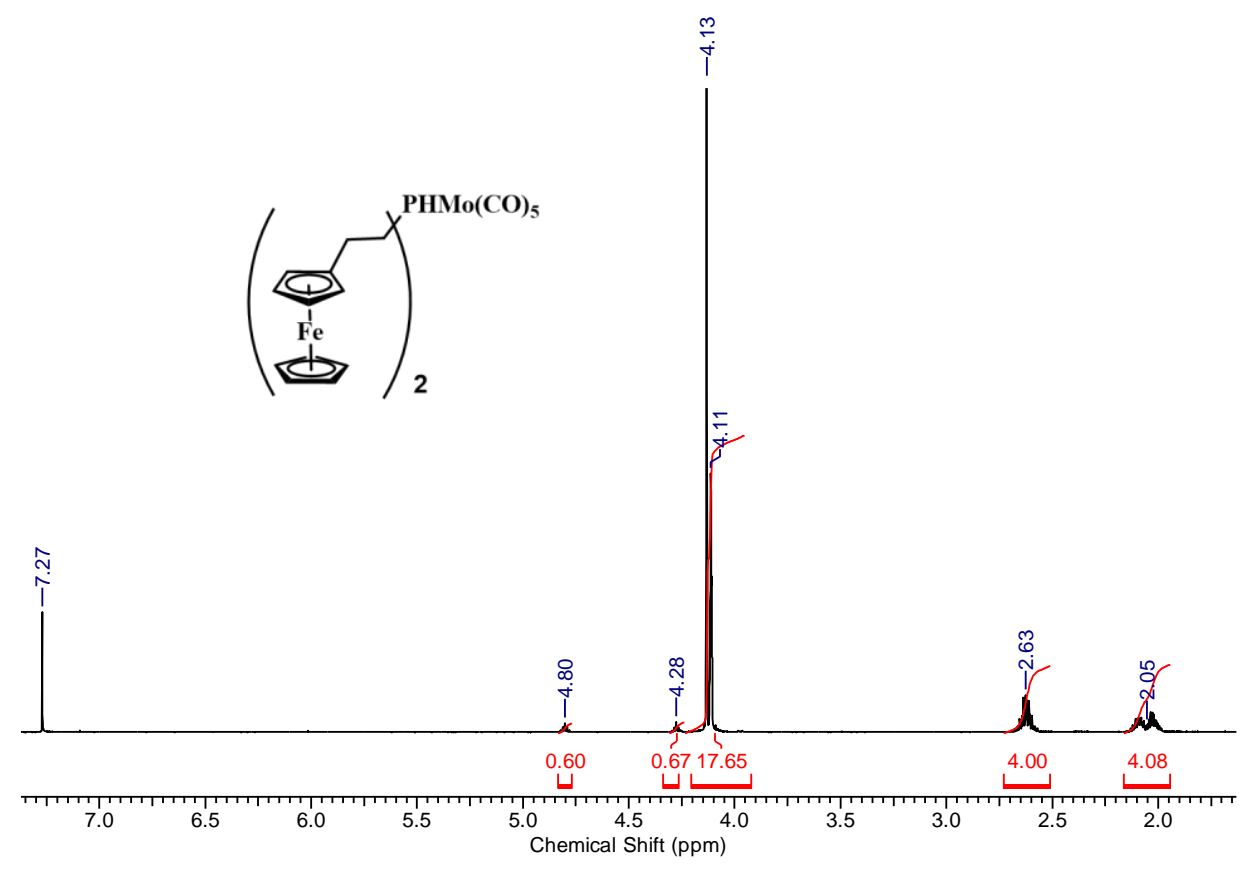

Fig. S17 ${ }^{1} \mathrm{H}$ NMR spectrum of $\mathbf{6 b}$ in $\mathrm{CDCl}_{3}$.

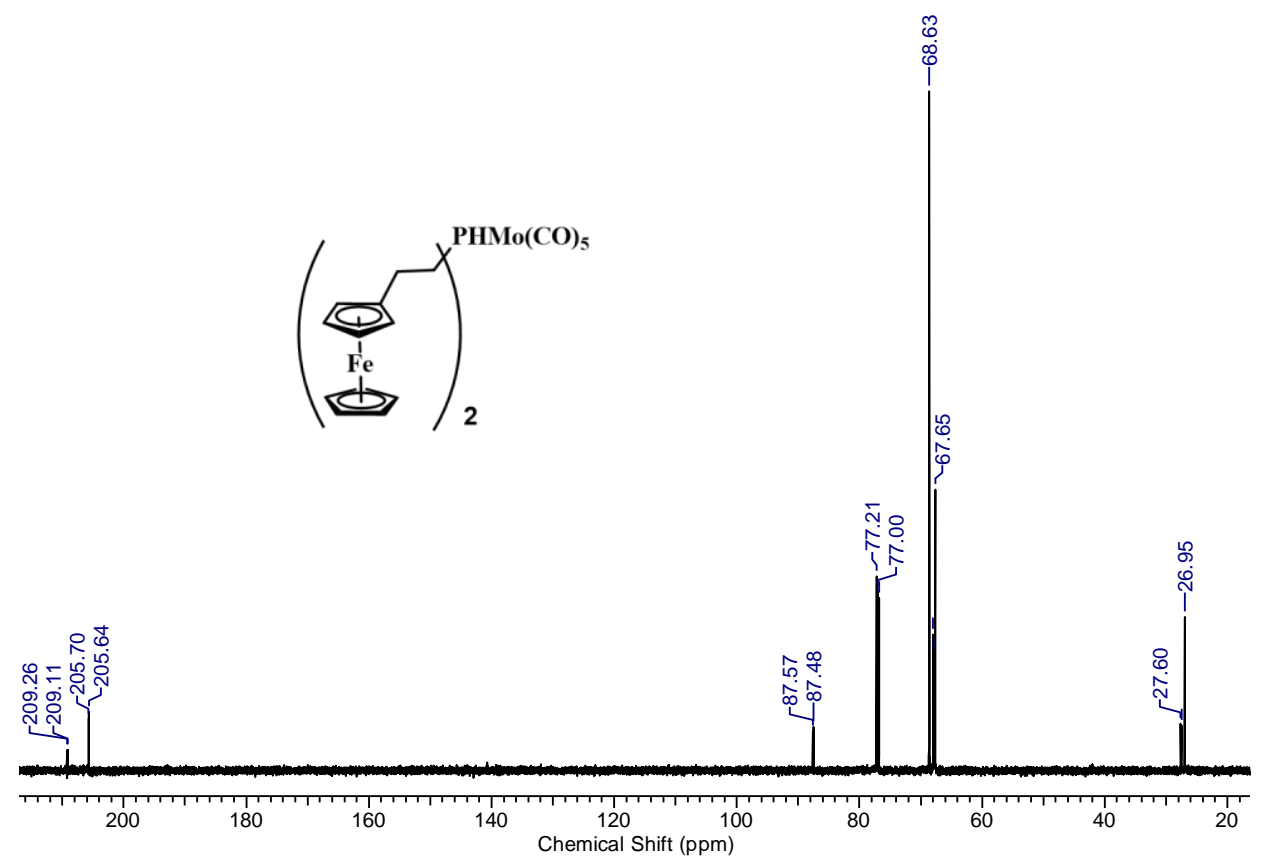

Fig. S18 ${ }^{13} \mathrm{C}\left\{{ }^{1} \mathrm{H}\right\}$ NMR spectrum of $\mathbf{6 b}$ in $\mathrm{CDCl}_{3}$. 

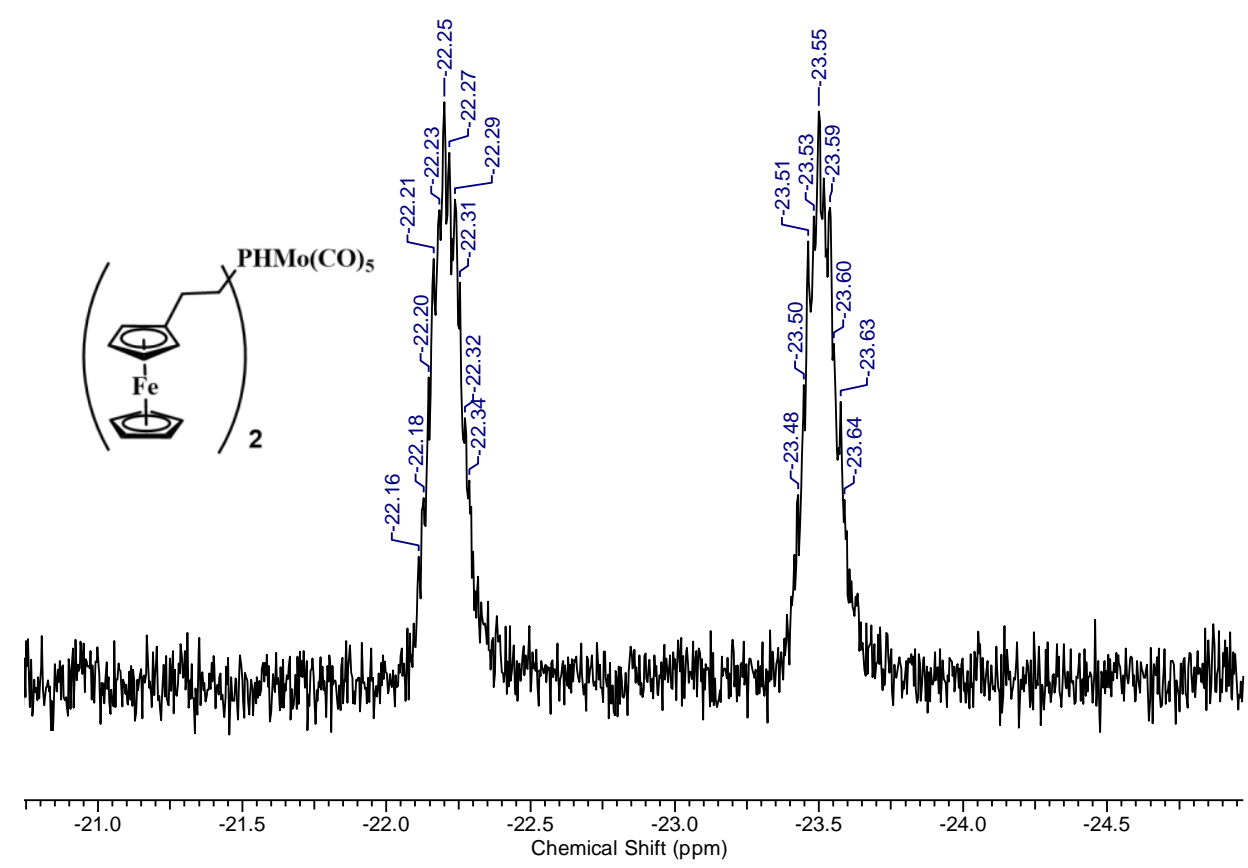

Fig. S19 ${ }^{31} \mathrm{P}$ NMR spectrum of $\mathbf{6 b}$ in $\mathrm{CDCl}_{3}$.

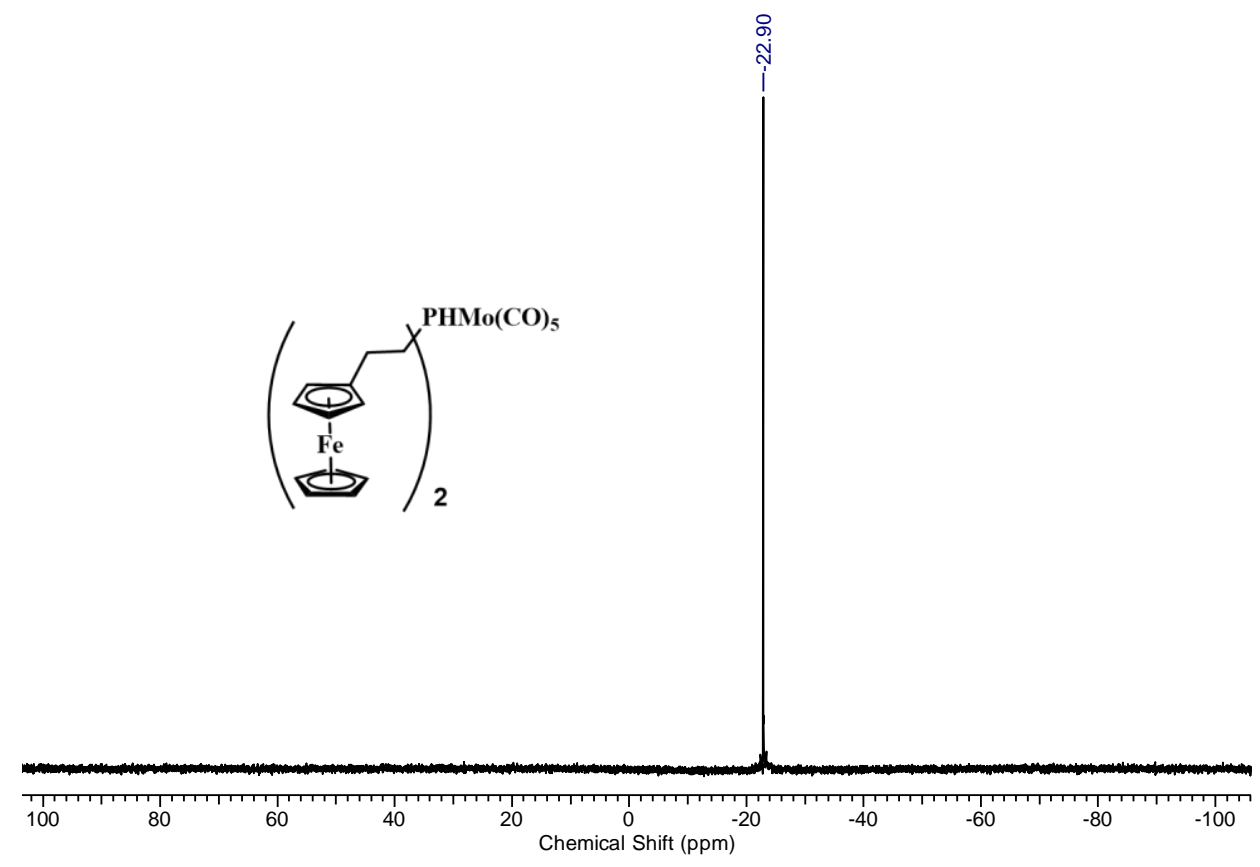

Fig. S20 ${ }^{31} \mathrm{P}\left\{{ }^{1} \mathrm{H}\right\}$ NMR spectrum of $\mathbf{6 b}$ in $\mathrm{CDCl}_{3}$. 


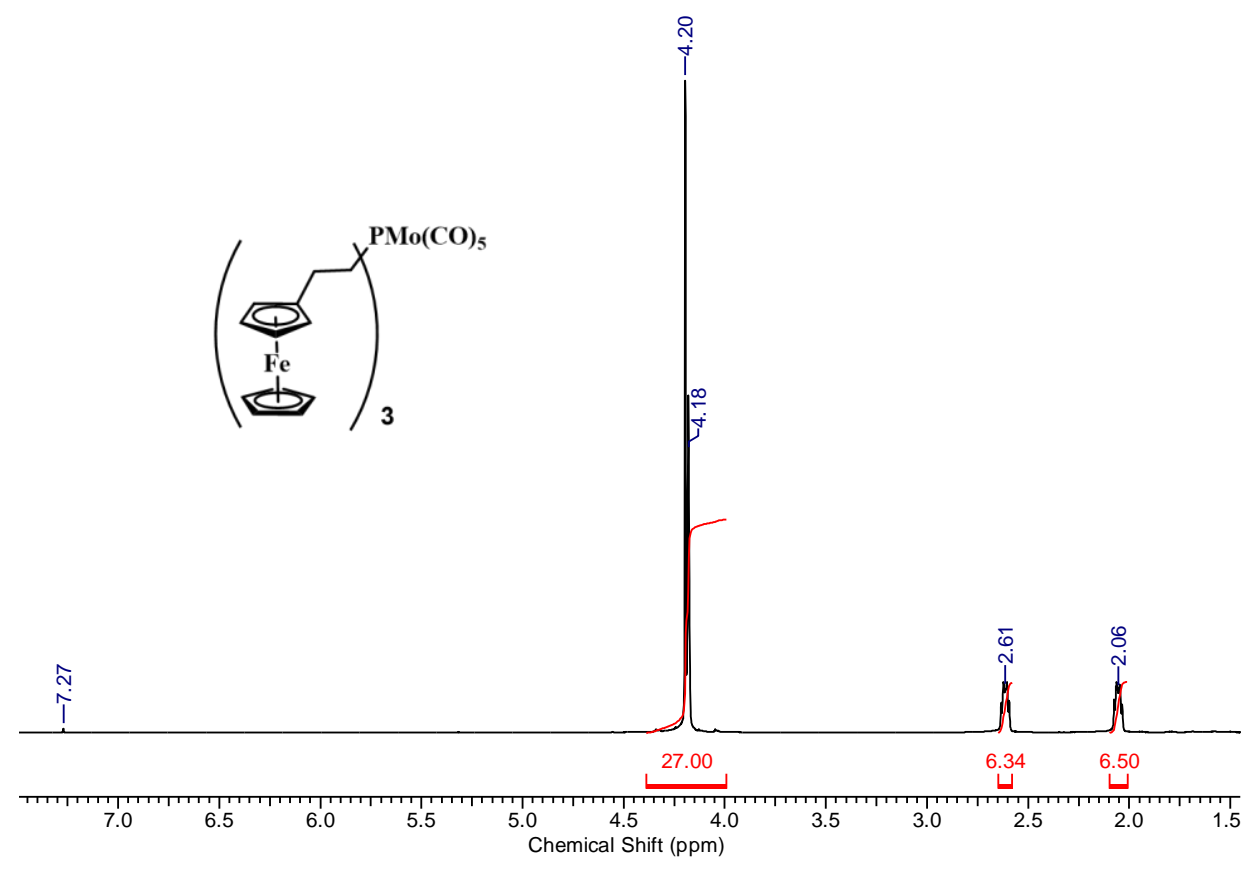

Fig. S21 ${ }^{1} \mathrm{H}$ NMR spectrum of $\mathbf{6 c}$ in $\mathrm{CDCl}_{3}$.

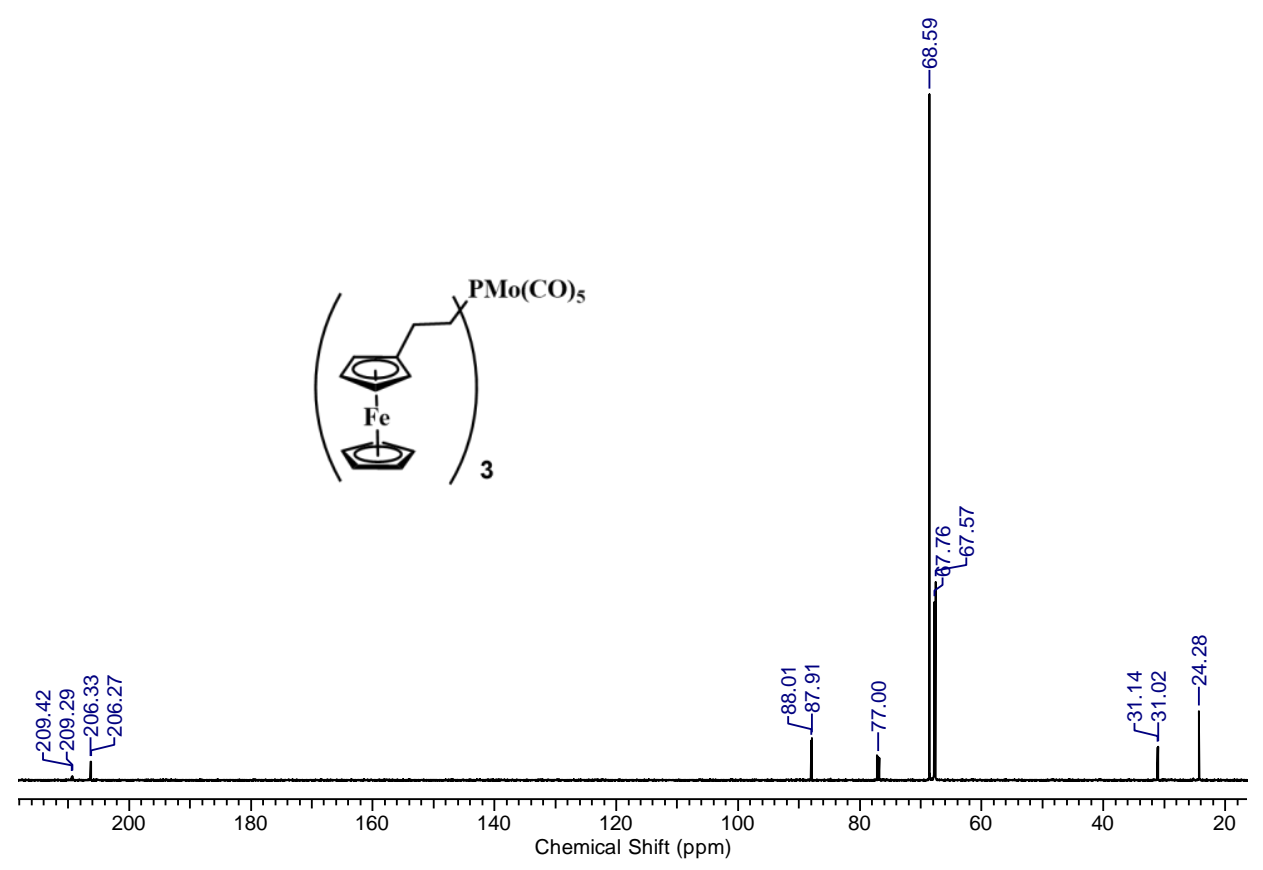

Fig. S22 ${ }^{13} \mathrm{C}\left\{{ }^{1} \mathrm{H}\right\}$ NMR spectrum of $\mathbf{6 c}$ in $\mathrm{CDCl}_{3}$. 


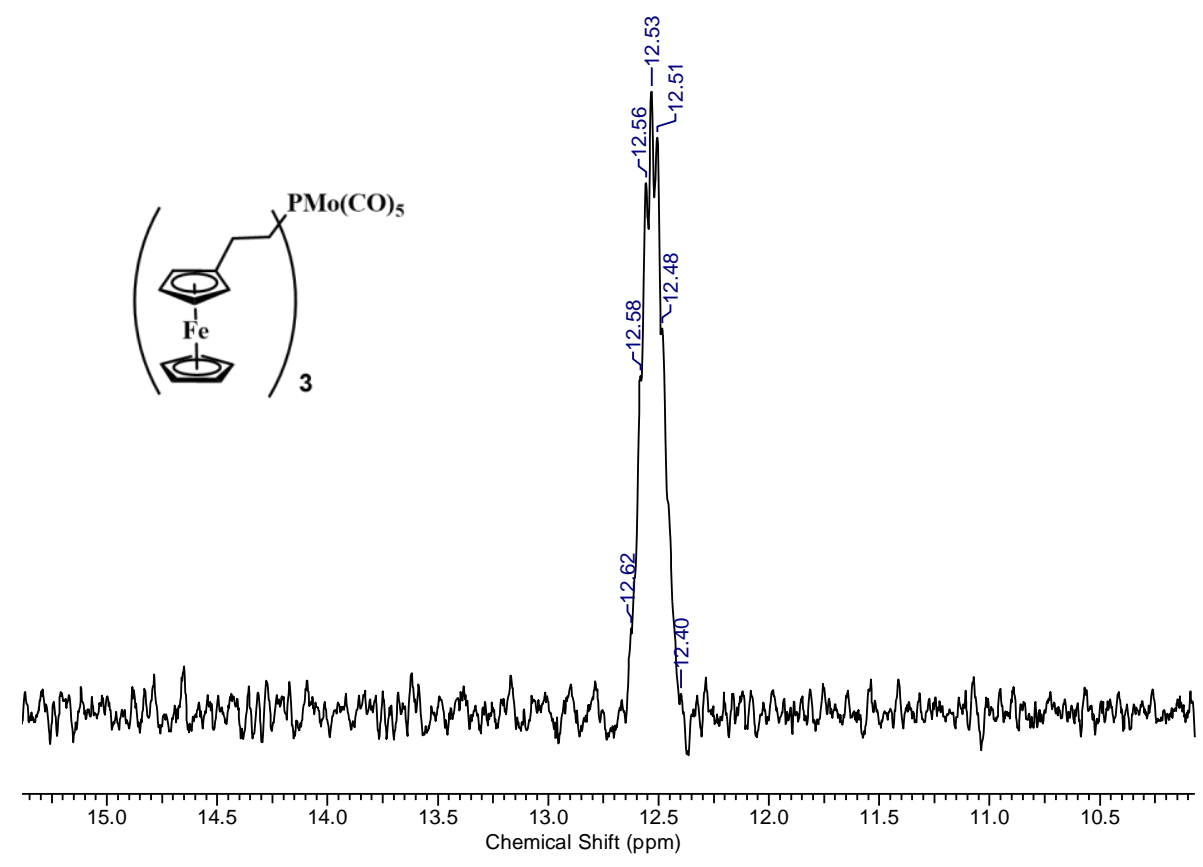

Fig. S23 ${ }^{31} \mathrm{P}$ NMR spectrum of $\mathbf{6 c}$ in $\mathrm{CDCl}_{3}$.

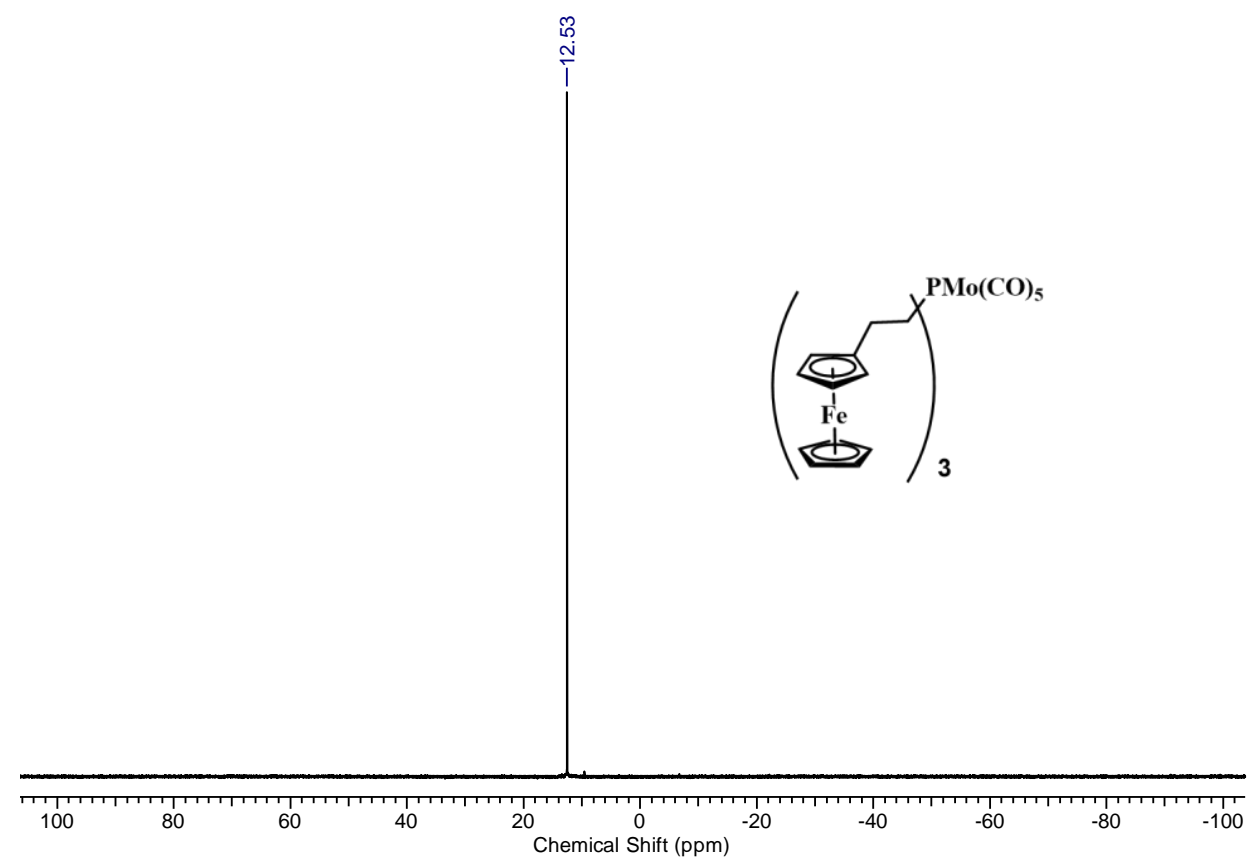

Fig. S24 ${ }^{31} \mathrm{P}\left\{{ }^{1} \mathrm{H}\right\}$ NMR spectrum of $\mathbf{6 c}$ in $\mathrm{CDCl}_{3}$. 


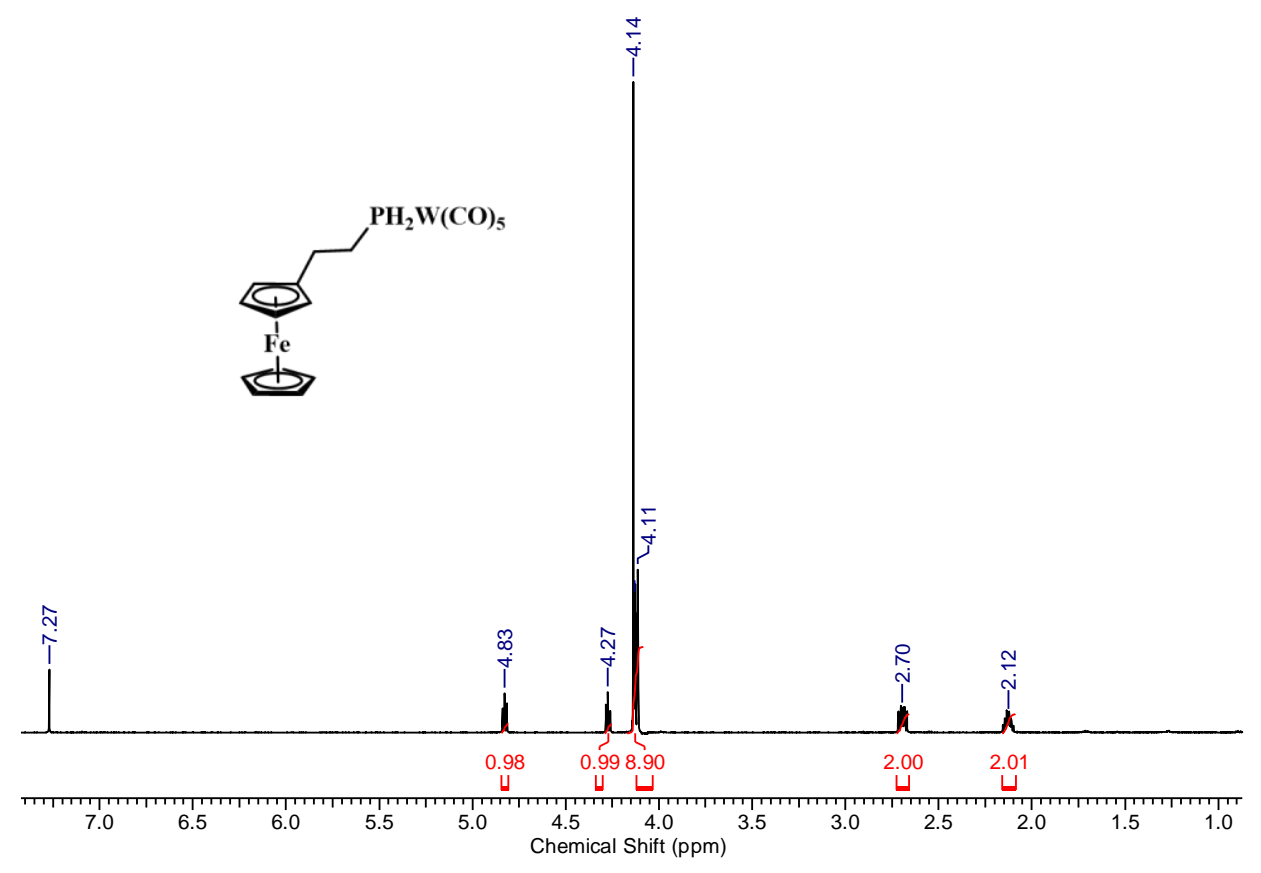

Fig. S25 ${ }^{1} \mathrm{H}$ NMR spectrum of $\mathbf{7 a}$ in $\mathrm{CDCl}_{3}$.

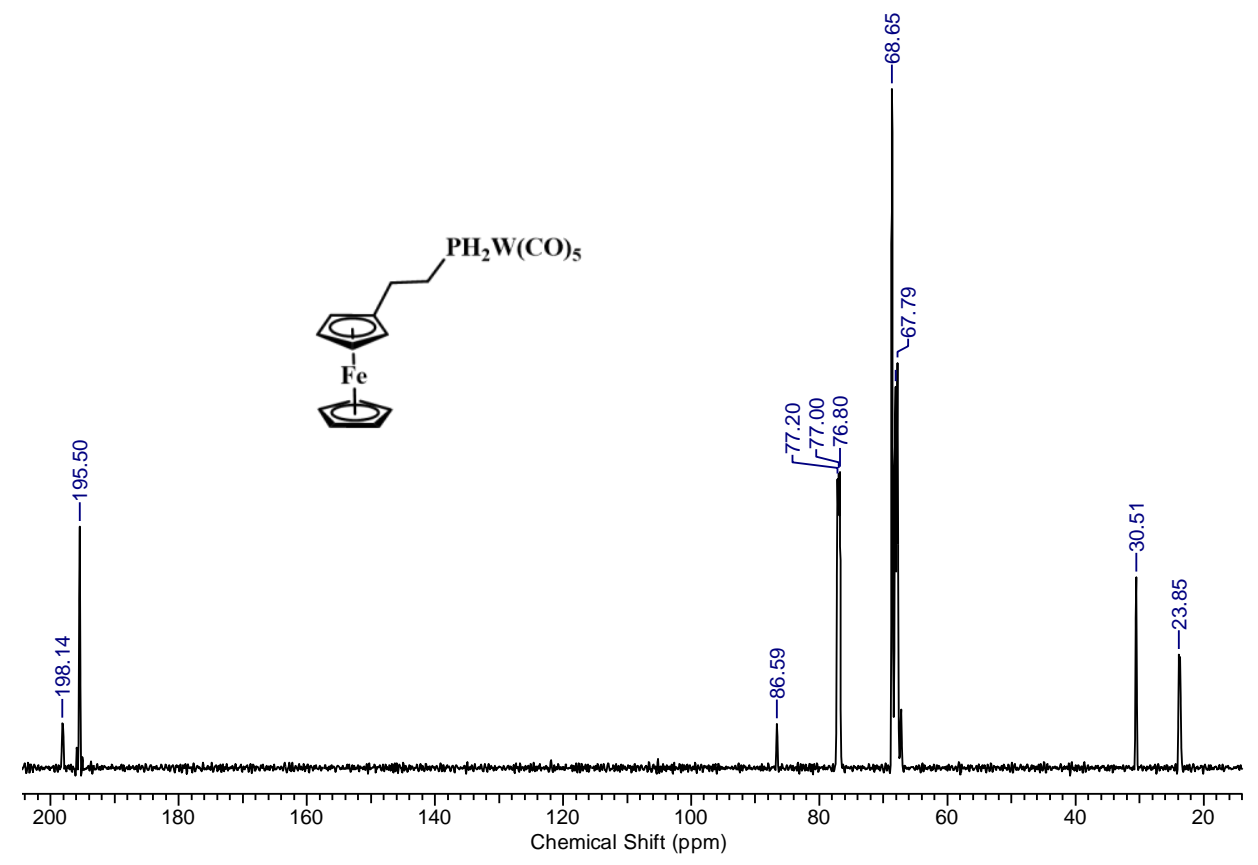

Fig. S26 ${ }^{13} \mathrm{C}\left\{{ }^{1} \mathrm{H}\right\}$ NMR spectrum of $\mathbf{7 a}$ in $\mathrm{CDCl}_{3}$. 


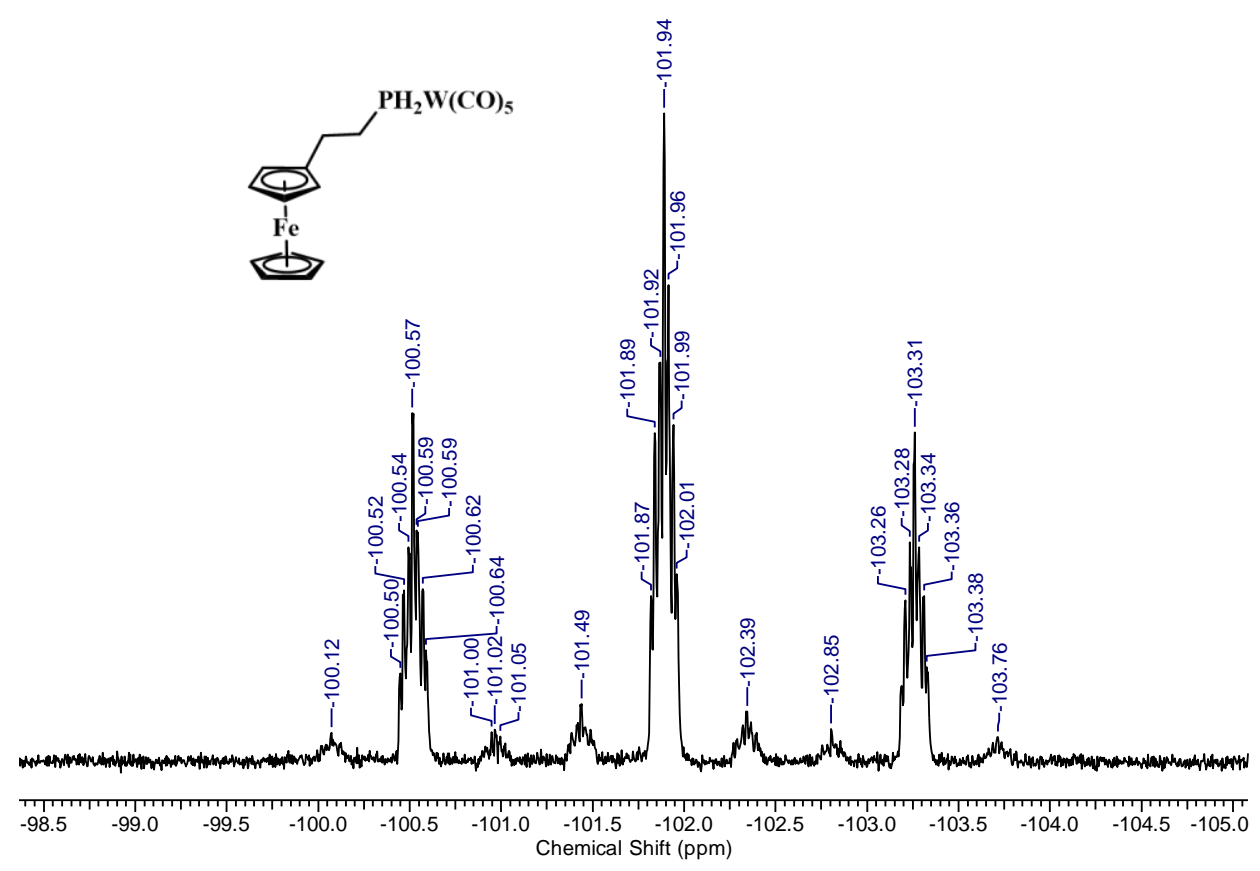

Fig. S27 ${ }^{31} \mathrm{P}$ NMR spectrum of $\mathbf{7 a}$ in $\mathrm{CDCl}_{3}$.

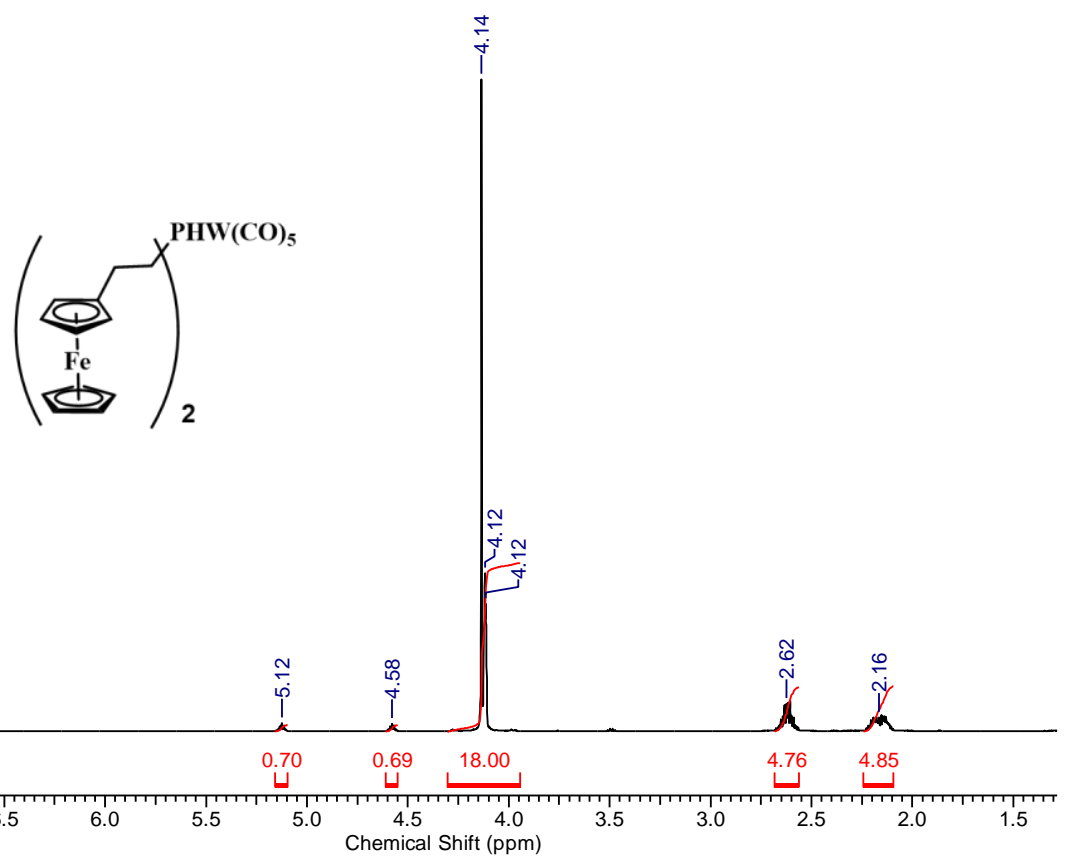

Fig. S28 ${ }^{1} \mathrm{H}$ NMR spectrum of $\mathbf{7 b}$ in $\mathrm{CDCl}_{3}$. 


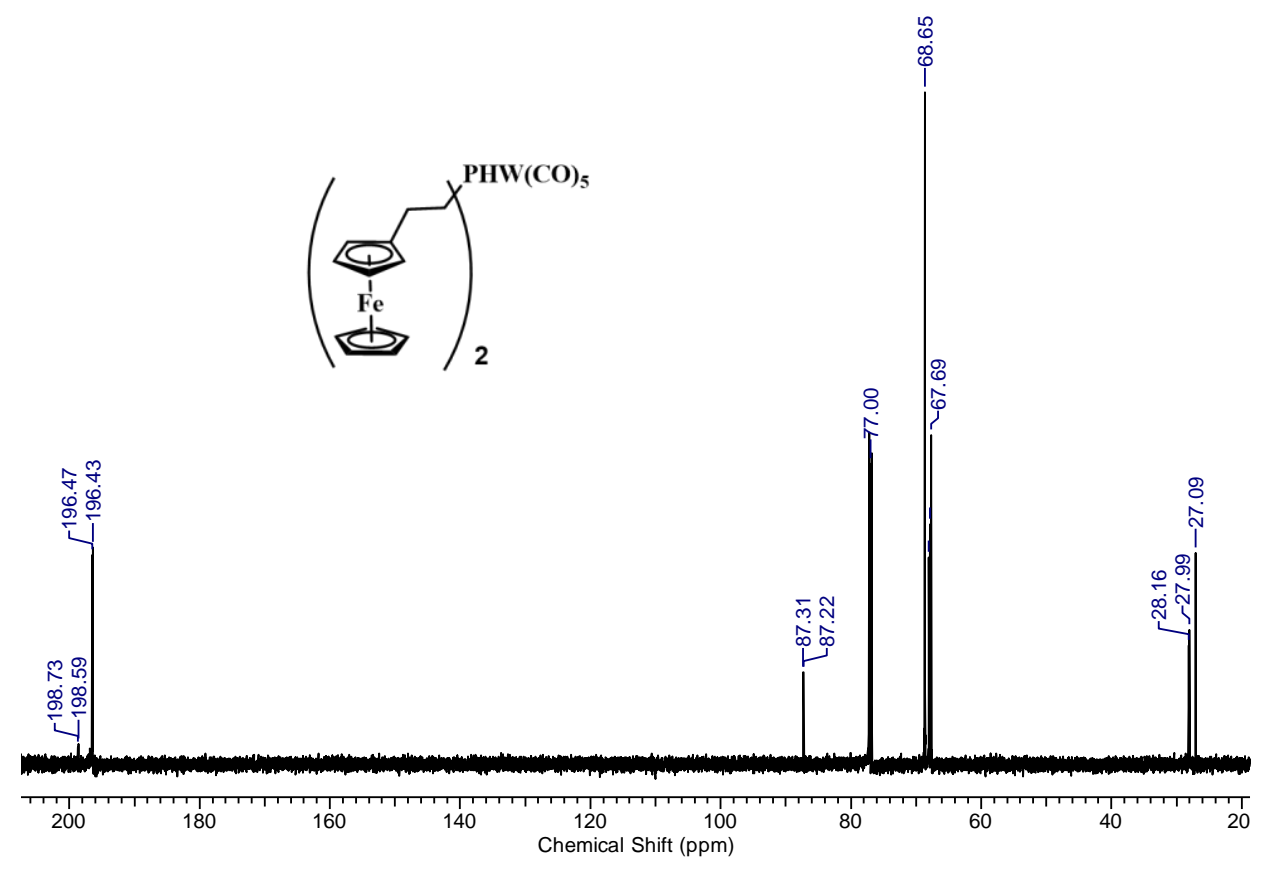

Fig. S29 ${ }^{13} \mathrm{C}\left\{{ }^{1} \mathrm{H}\right\}$ NMR spectrum of $\mathbf{7 b}$ in $\mathrm{CDCl}_{3}$.

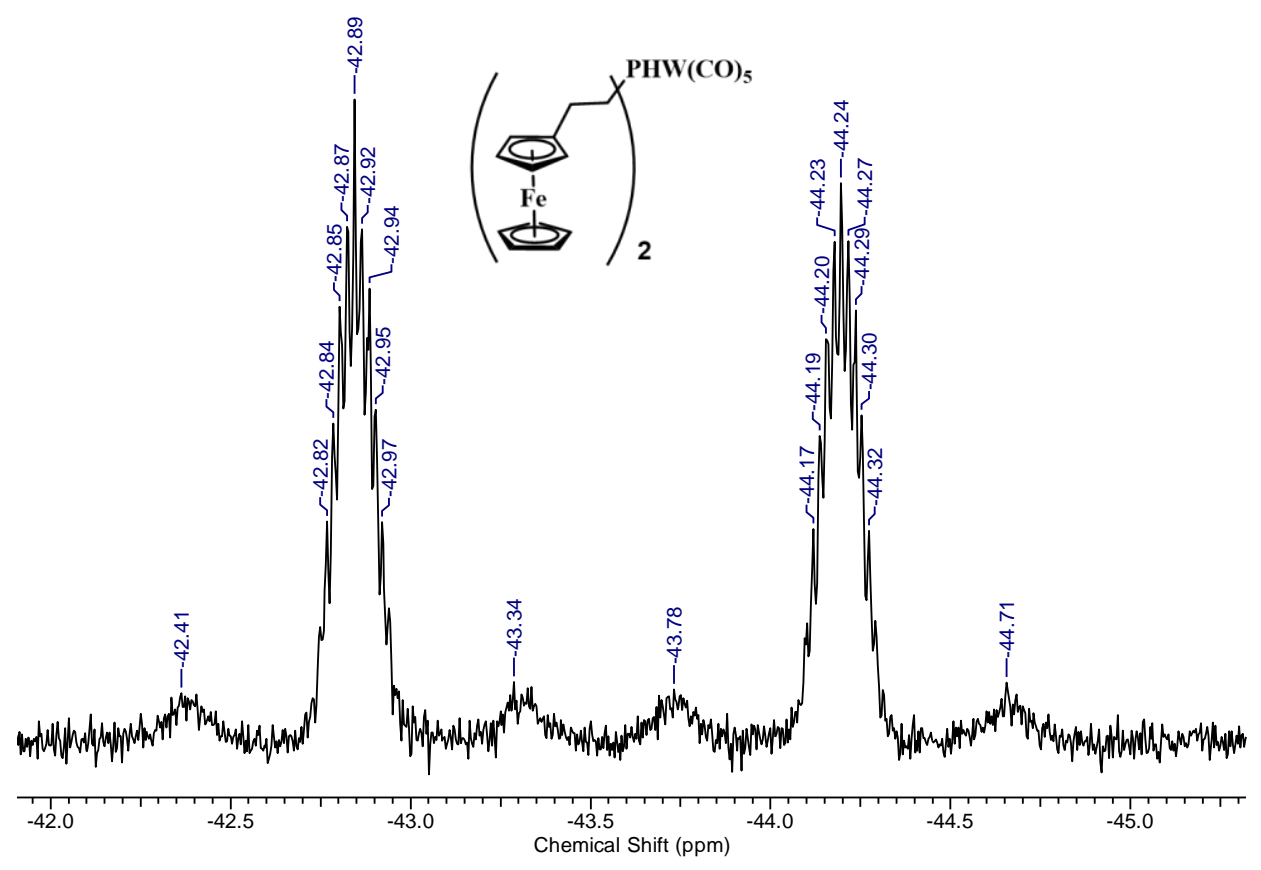

Fig. S30 ${ }^{31} \mathrm{P}$ NMR spectrum of $\mathbf{7 b}$ in $\mathrm{CDCl}_{3}$. 


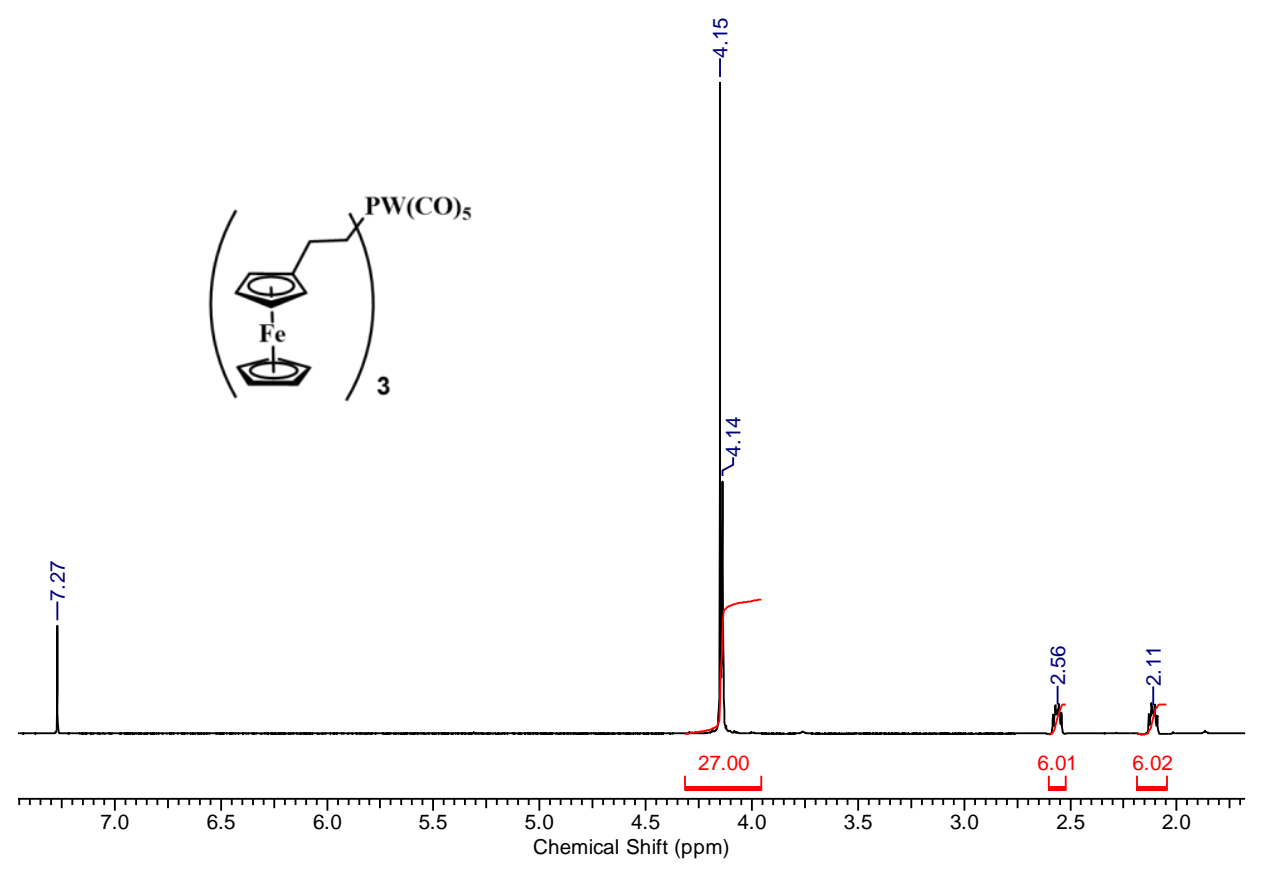

Fig. S31 ${ }^{1} \mathrm{H}$ NMR spectrum of 7c in $\mathrm{CDCl}_{3}$.

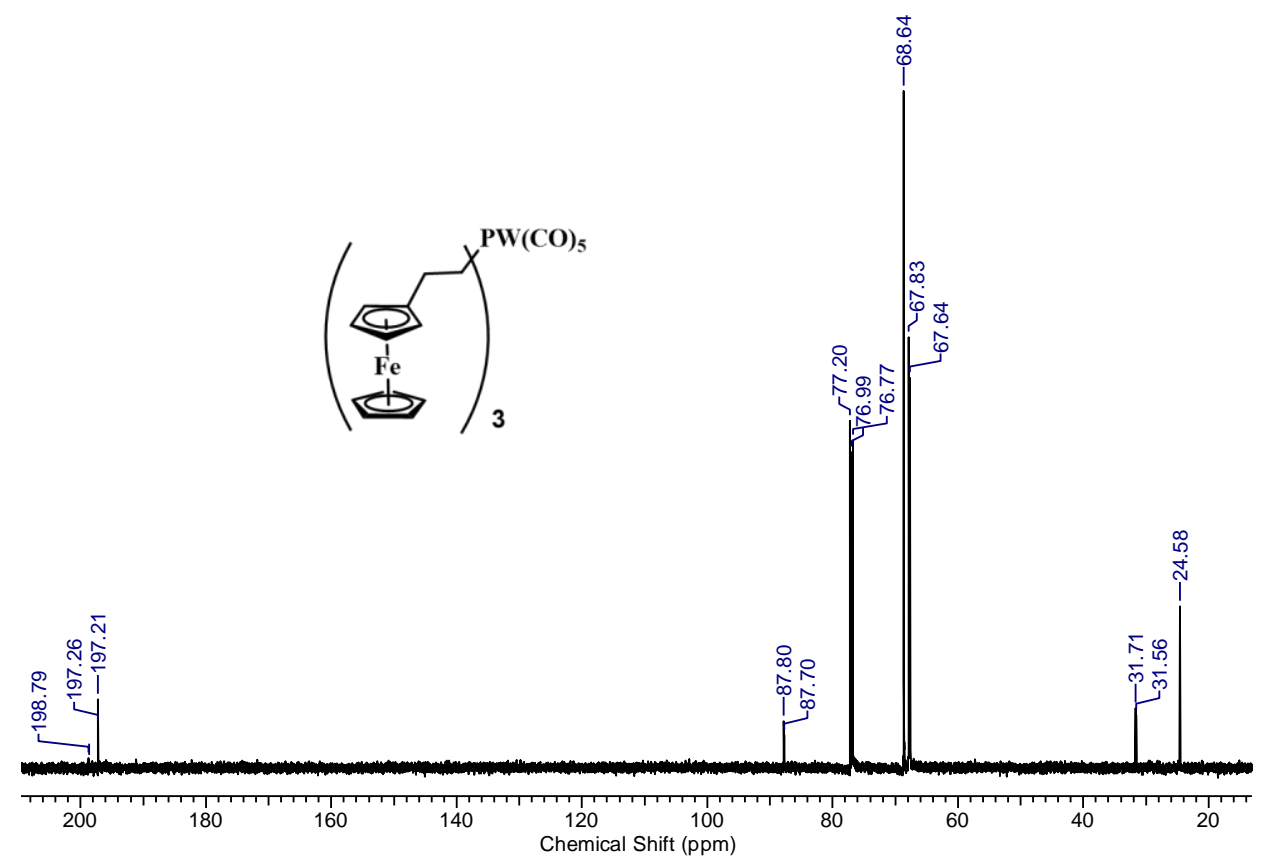

Fig. S32 ${ }^{13} \mathrm{C}\left\{{ }^{1} \mathrm{H}\right\}$ NMR spectrum of $7 \mathbf{c}$ in $\mathrm{CDCl}_{3}$. 


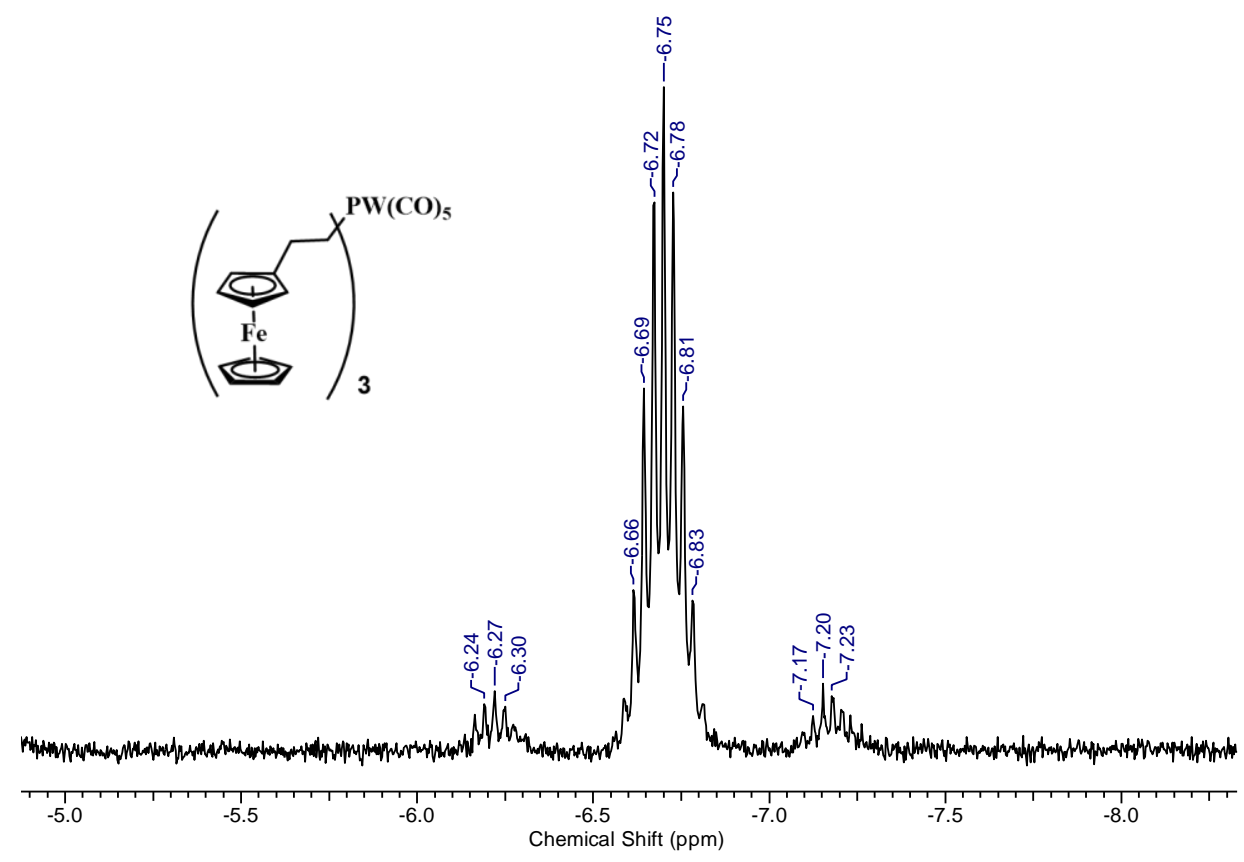

Fig. S33 ${ }^{31} \mathrm{P}$ NMR spectrum of $7 \mathbf{c}$ in $\mathrm{CDCl}_{3}$.

\section{Solid-state structures}

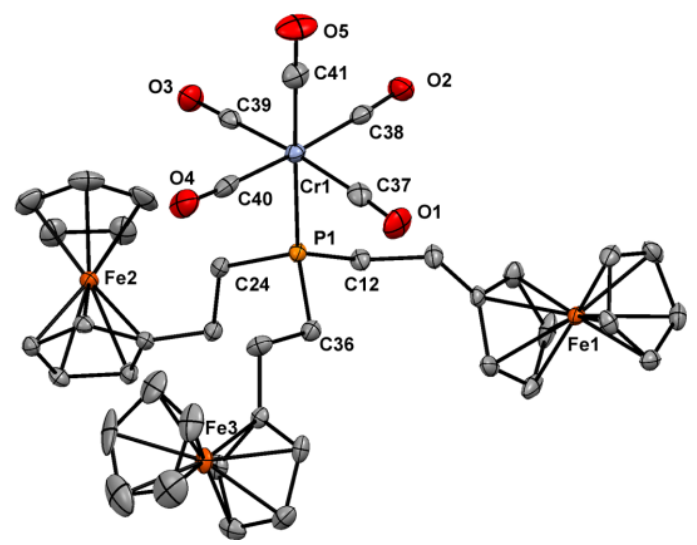

Fig. S34 Solid-state structure of 5c. Anisotropic displacement ellipsoids are shown at 50\% probability and hydrogen atoms have been omitted for clarity. 


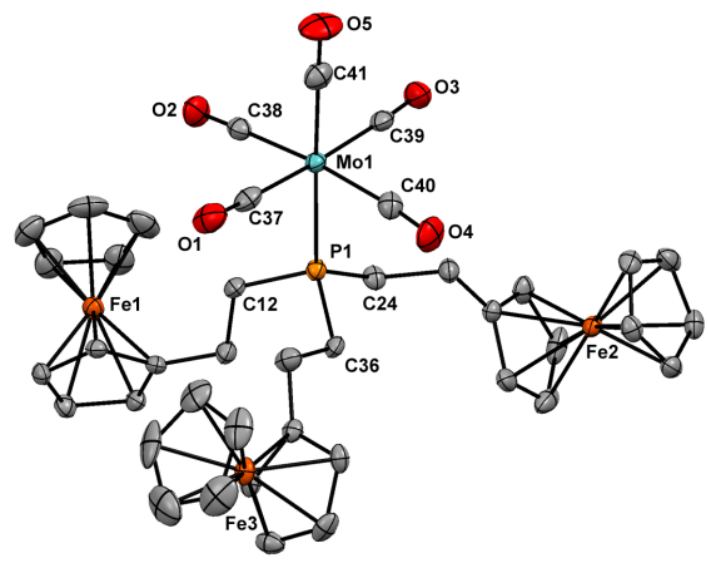

Fig. S35 Solid-state structure of $\mathbf{6 c}$. Anisotropic displacement ellipsoids are shown at 50\% probability and hydrogen atoms have been omitted for clarity.

FT-IR absorption spectra

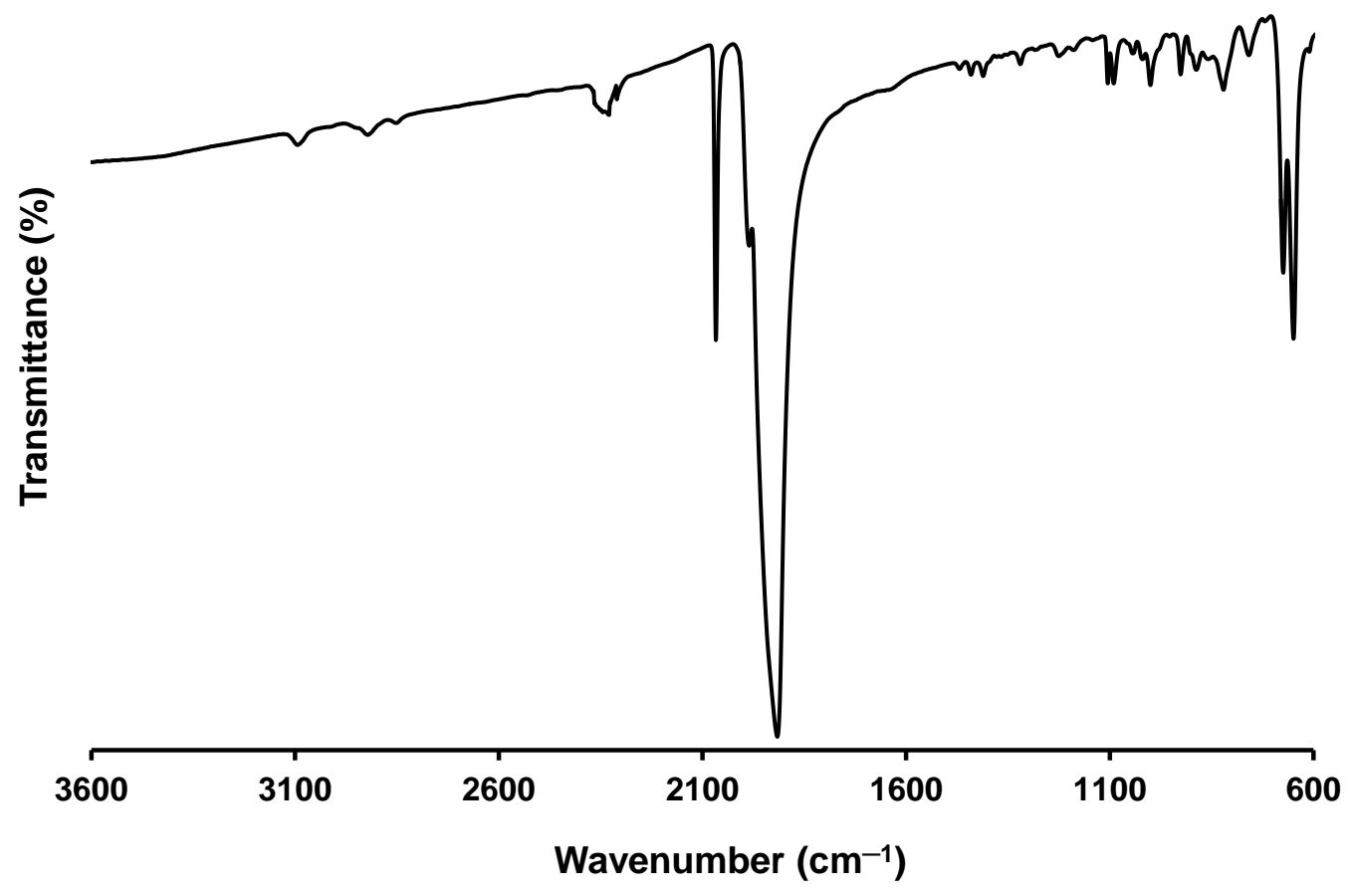

Fig. S36 FT-IR absorption spectrum of 5a recorded as a thin film on a KBr plate. 


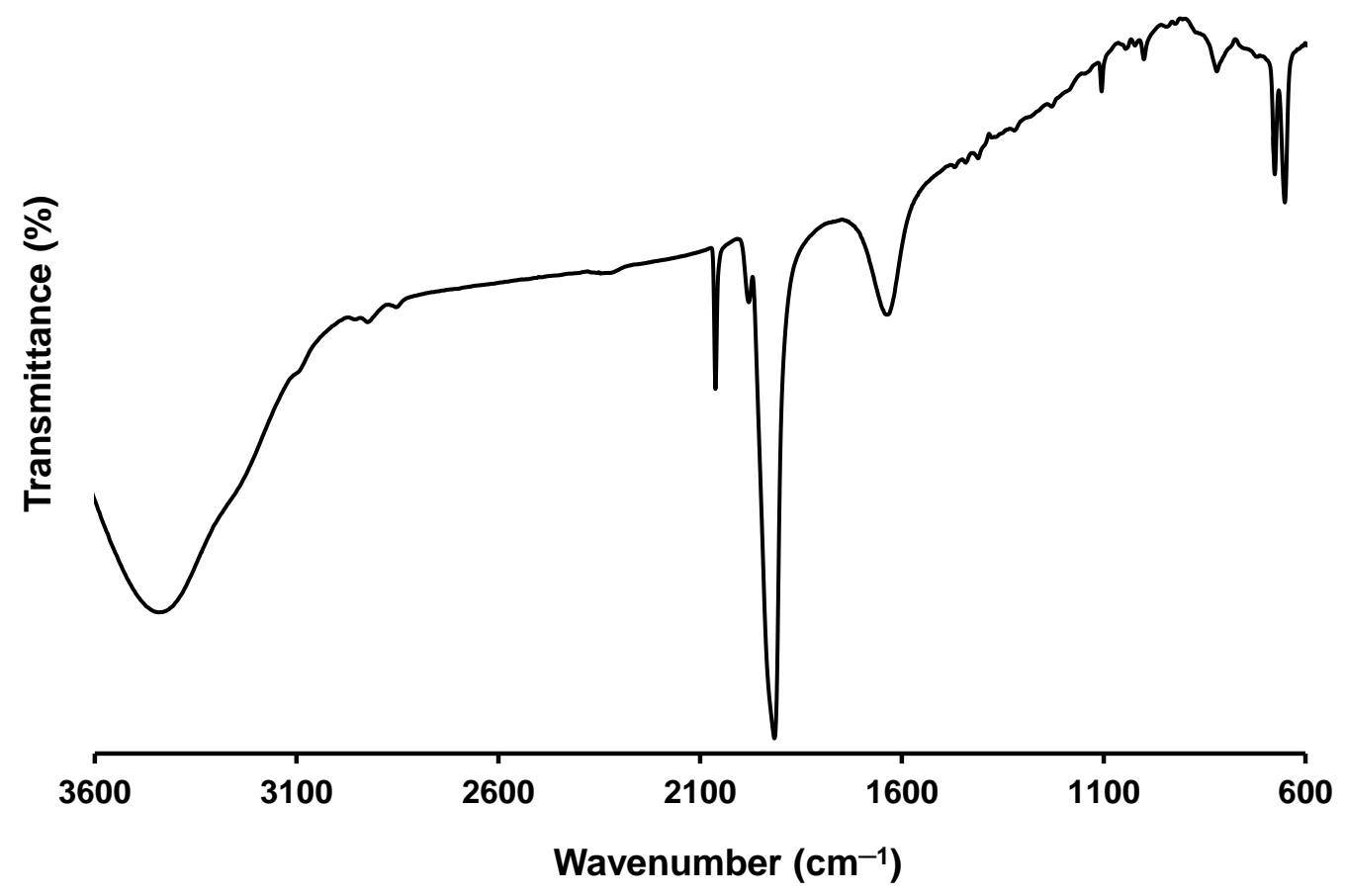

Fig. S37 FT-IR absorption spectrum of $\mathbf{5 b}$ recorded as a thin film on a $\mathrm{KBr}$ plate.

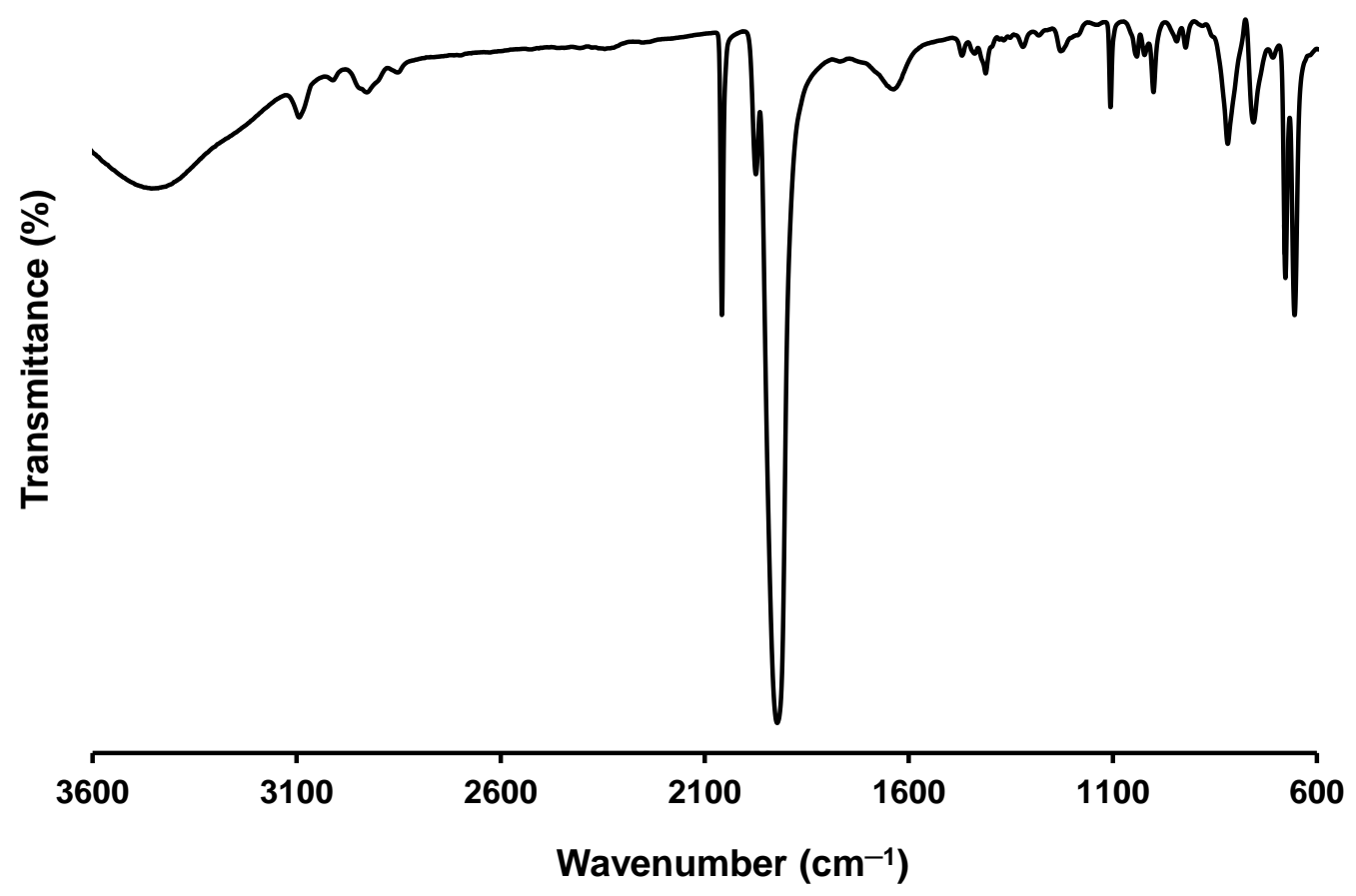

Fig. S38 FT-IR absorption spectrum of $\mathbf{5 c}$ recorded as a thin film on a $\mathrm{KBr}$ plate. 


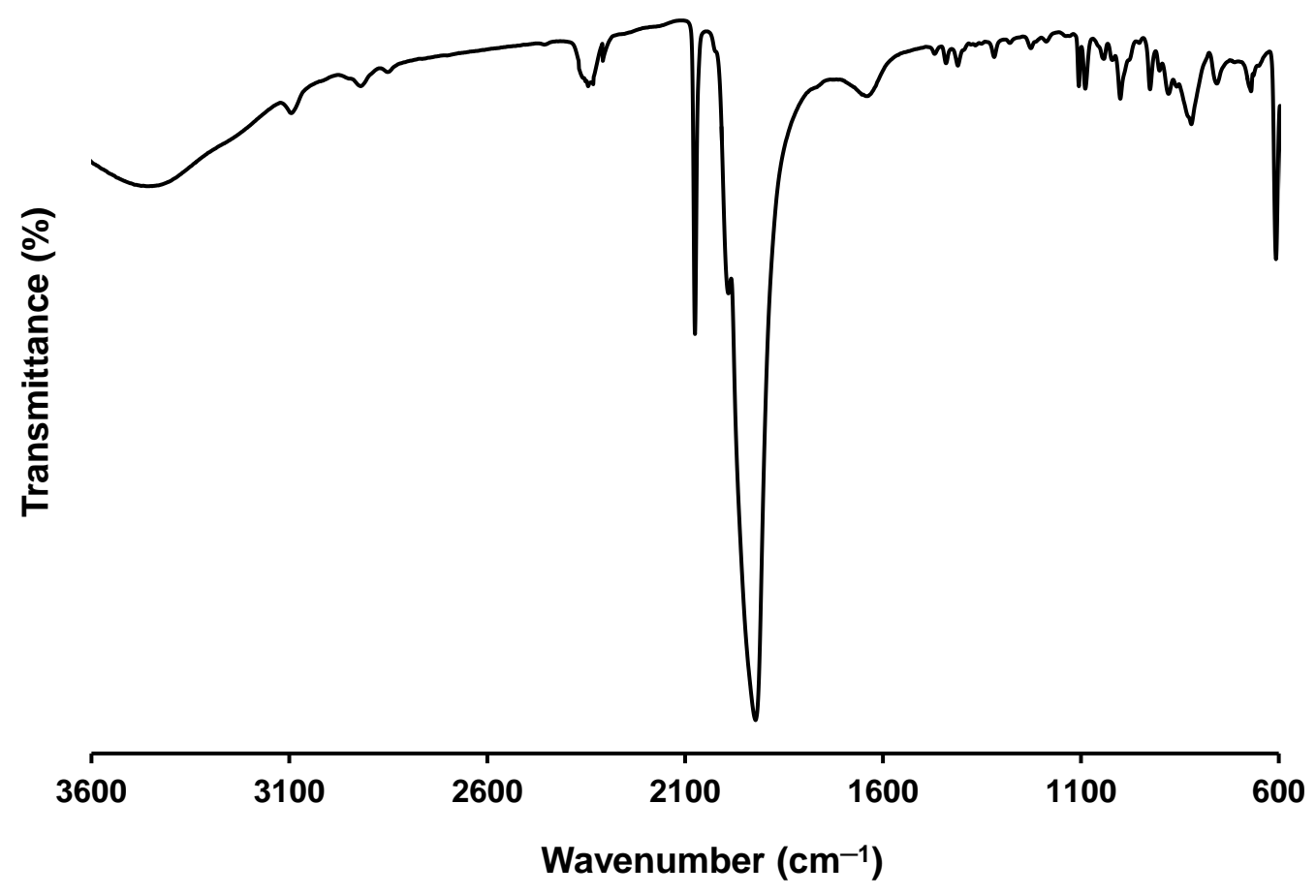

Fig. S39 FT-IR absorption spectrum of 6 a recorded as a thin film on a $\mathrm{KBr}$ plate.

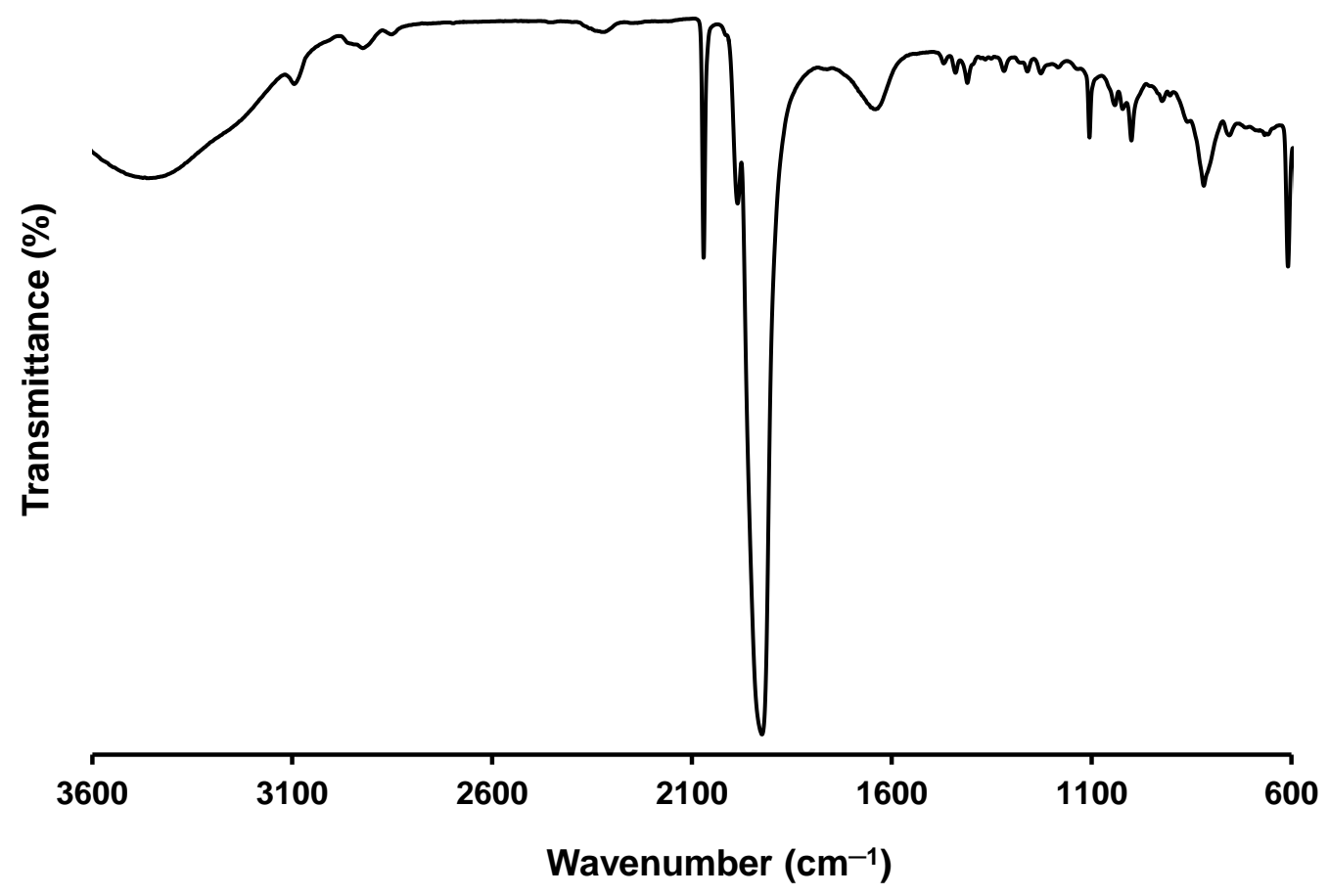

Fig. S40 FT-IR absorption spectrum of $\mathbf{6 b}$ recorded as a thin film on a $\mathrm{KBr}$ plate. 


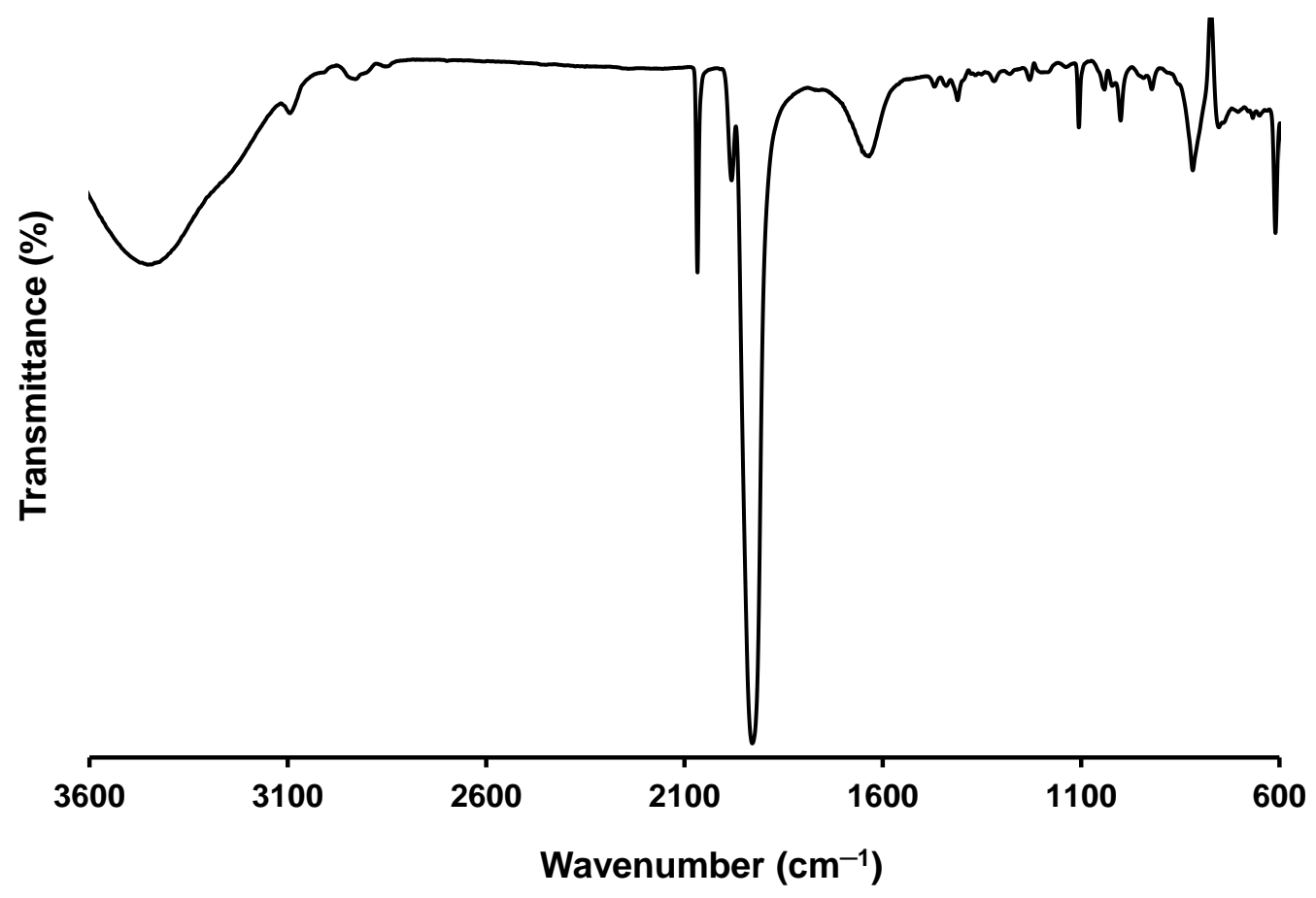

Fig. S41 FT-IR absorption spectrum of $\mathbf{6 c}$ recorded as a thin film on a $\mathrm{KBr}$ plate.

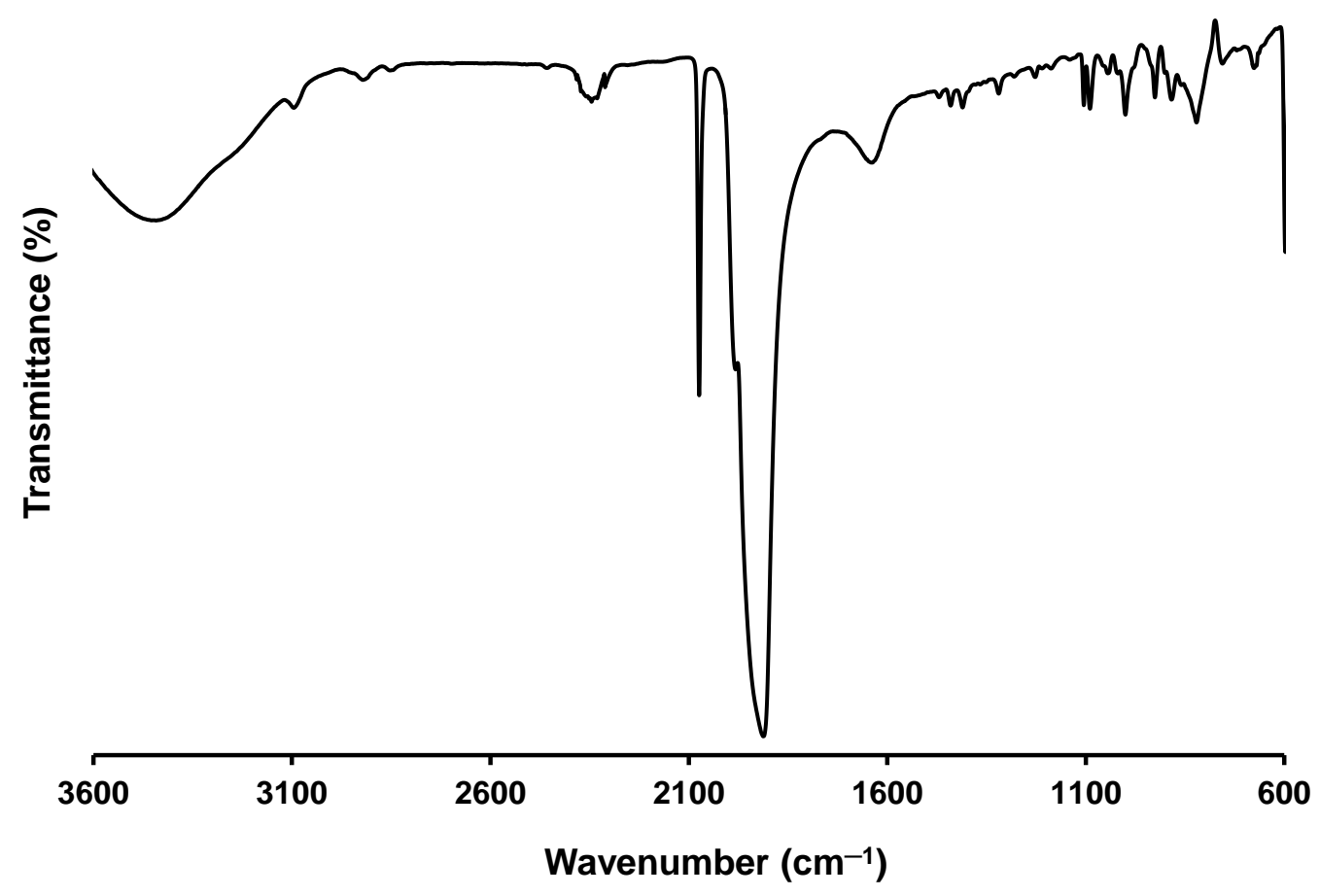

Fig. S42 FT-IR absorption spectrum of 7a recorded as a thin film on a $\mathrm{KBr}$ plate. 


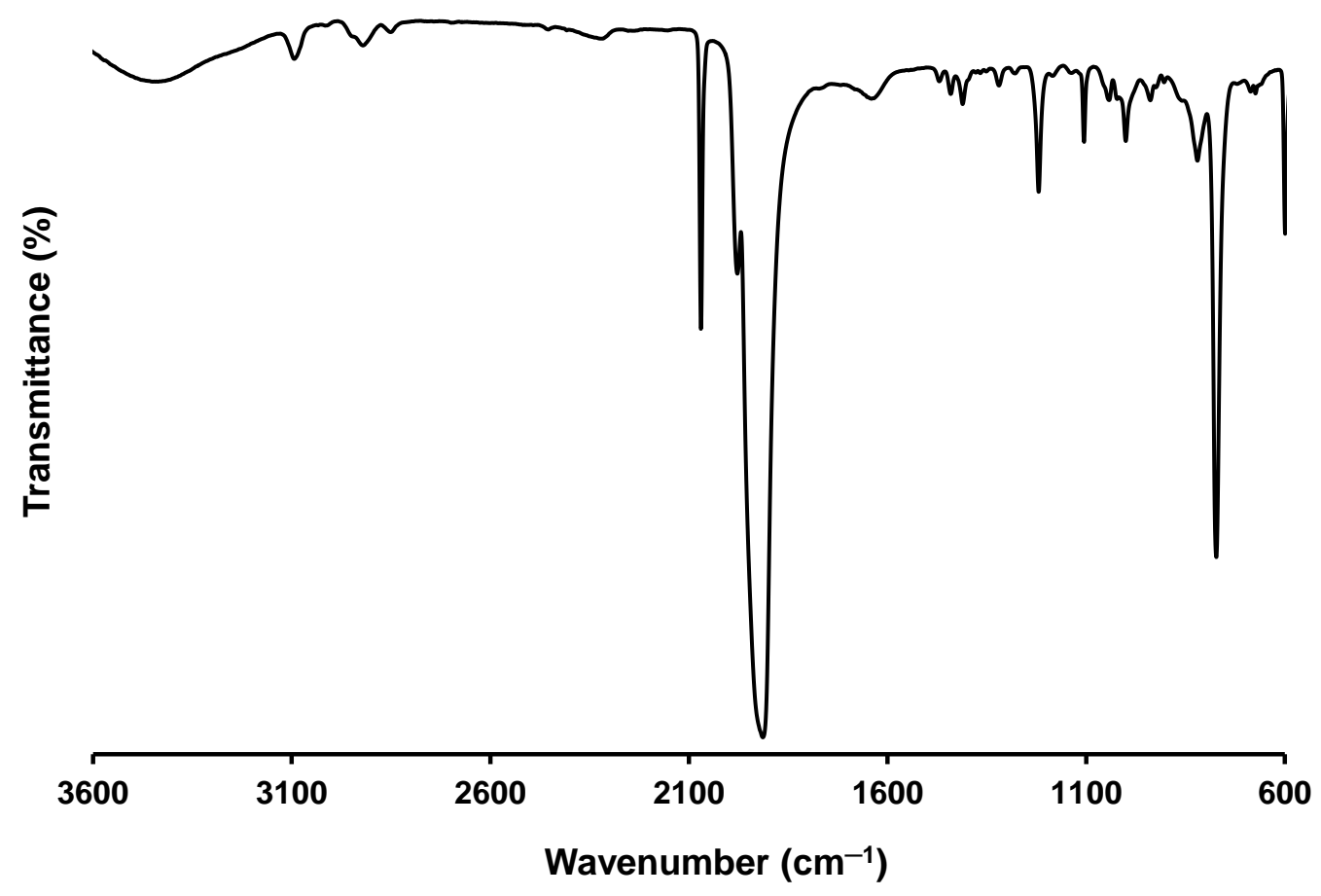

Fig. S43 FT-IR absorption spectrum of $\mathbf{7 b}$ recorded as a thin film on a $\mathrm{KBr}$ plate.

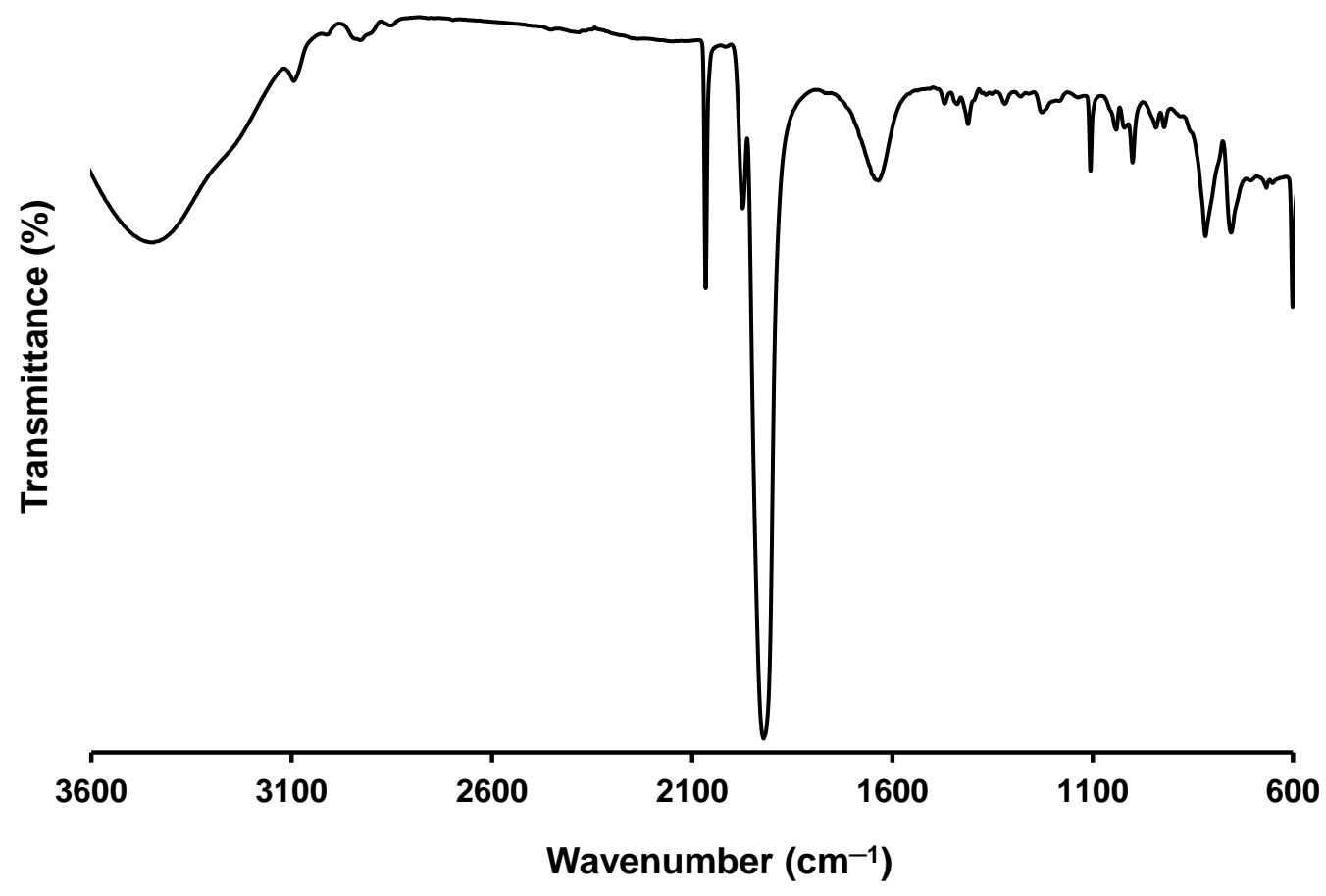

Fig. S44 FT-IR absorption spectrum of 7c recorded as a thin film on a KBr plate. 


\section{UV-Vis Absorption Spectra}

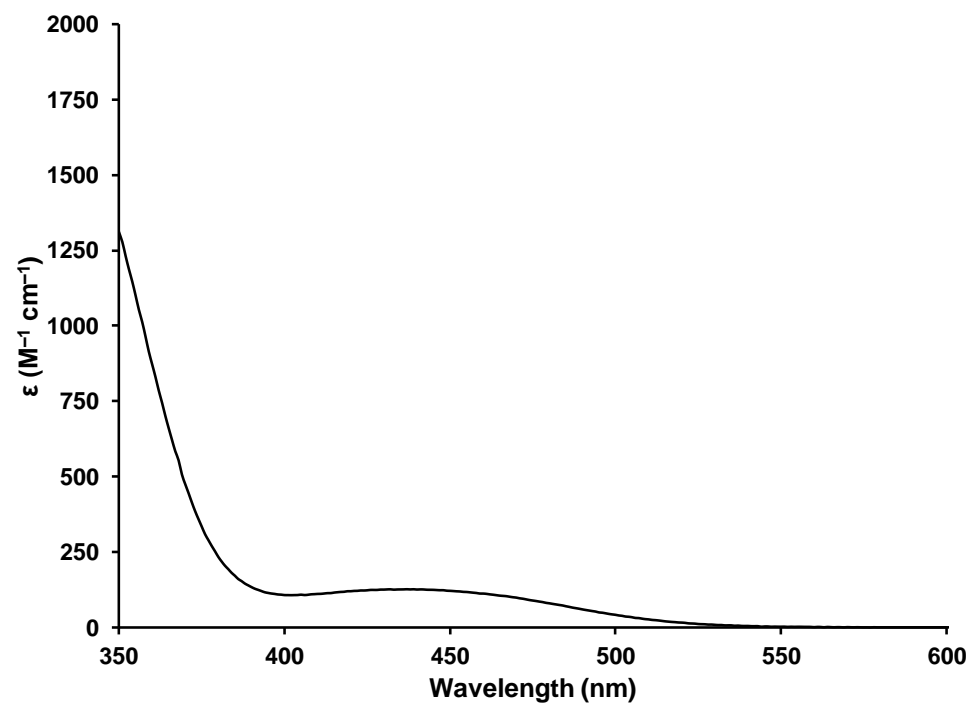

Fig. S45 UV-Vis absorption spectrum of 5 a recorded in $\mathrm{CH}_{2} \mathrm{Cl}_{2}$.

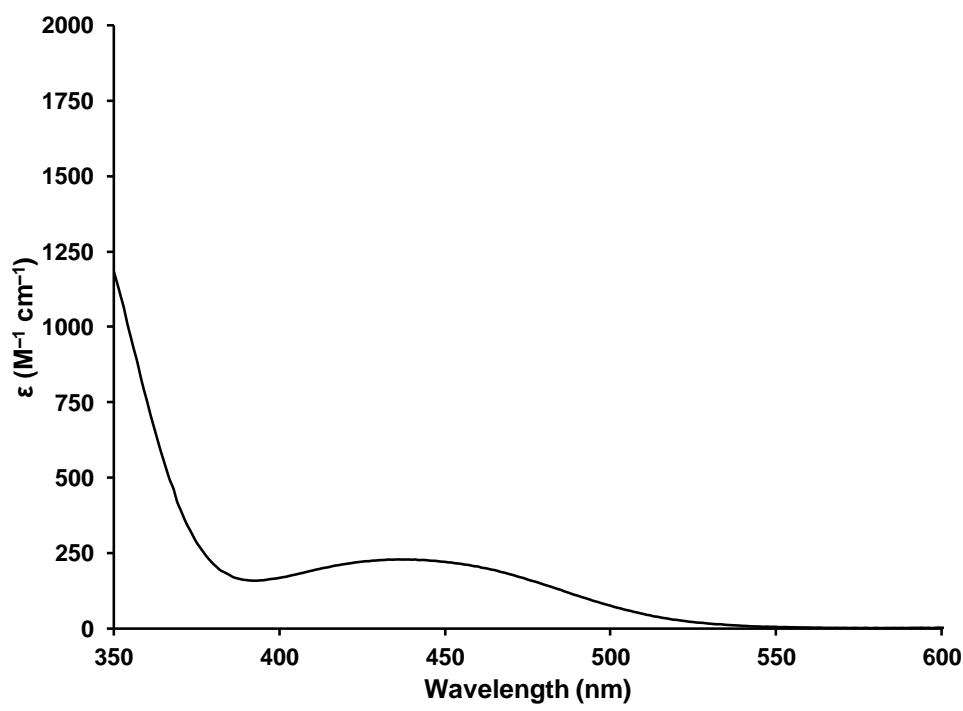

Fig. S46 UV-Vis absorption spectrum of $\mathbf{5 b}$ recorded in $\mathrm{CH}_{2} \mathrm{Cl}_{2}$. 


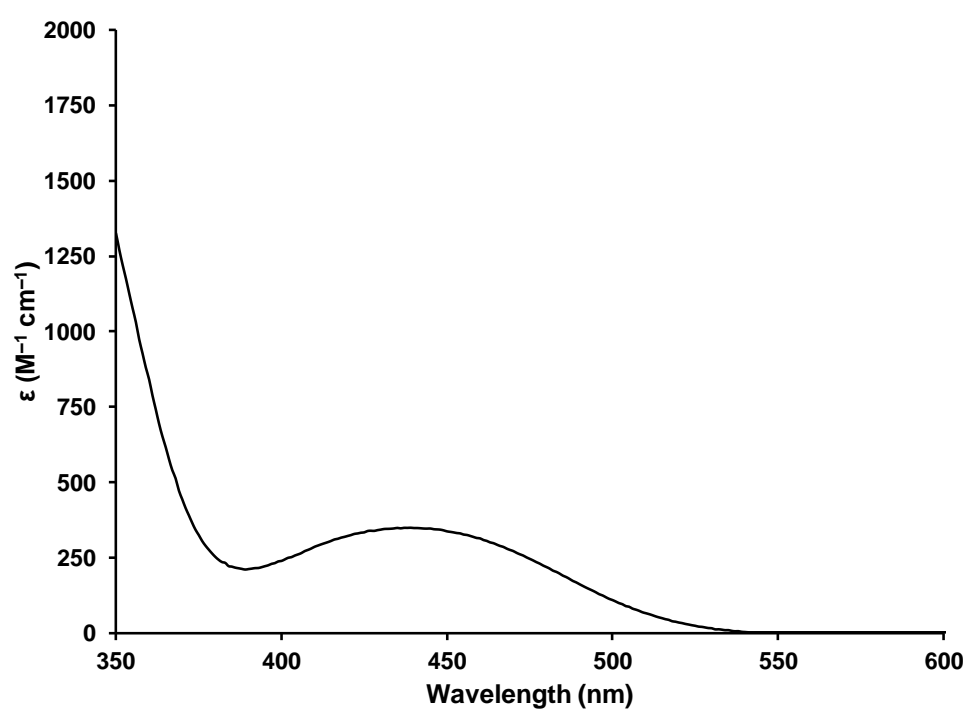

Fig. S47 UV-Vis absorption spectrum of $5 \mathbf{c}$ recorded in $\mathrm{CH}_{2} \mathrm{Cl}_{2}$.

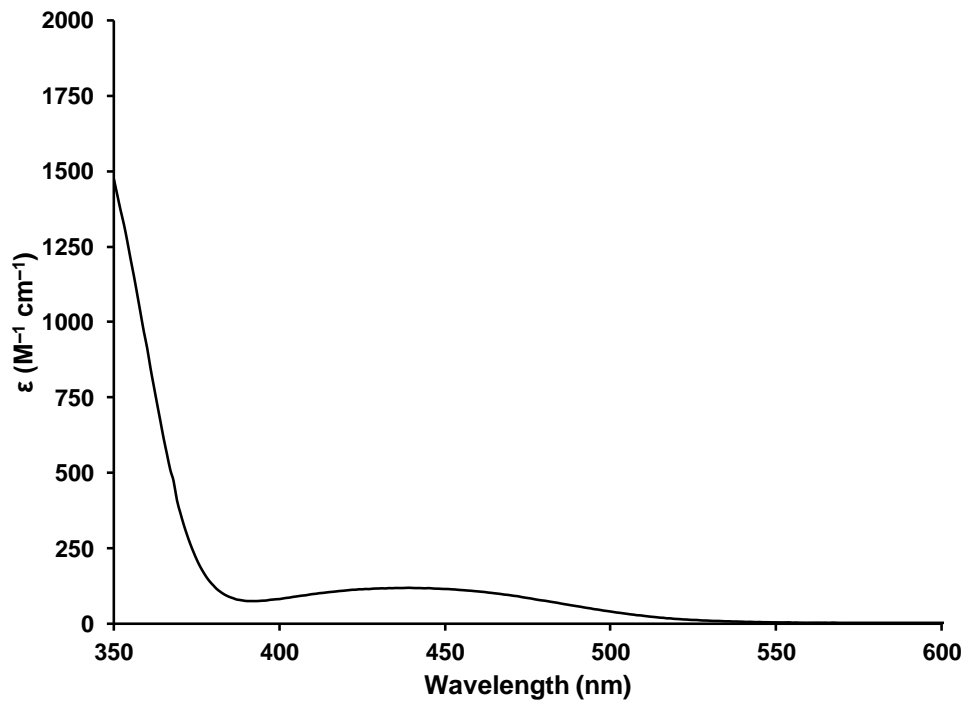

Fig. S48 UV-Vis absorption spectrum of 6 a recorded in $\mathrm{CH}_{2} \mathrm{Cl}_{2}$. 


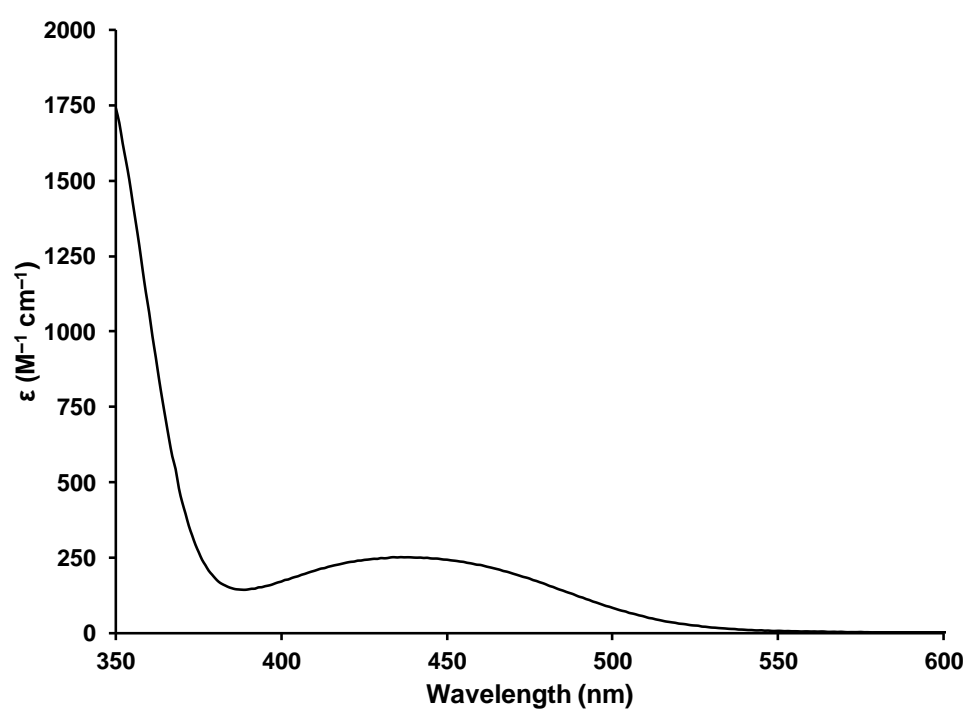

Fig. S49 UV-Vis absorption spectrum of $6 \mathbf{b}$ recorded in $\mathrm{CH}_{2} \mathrm{Cl}_{2}$.

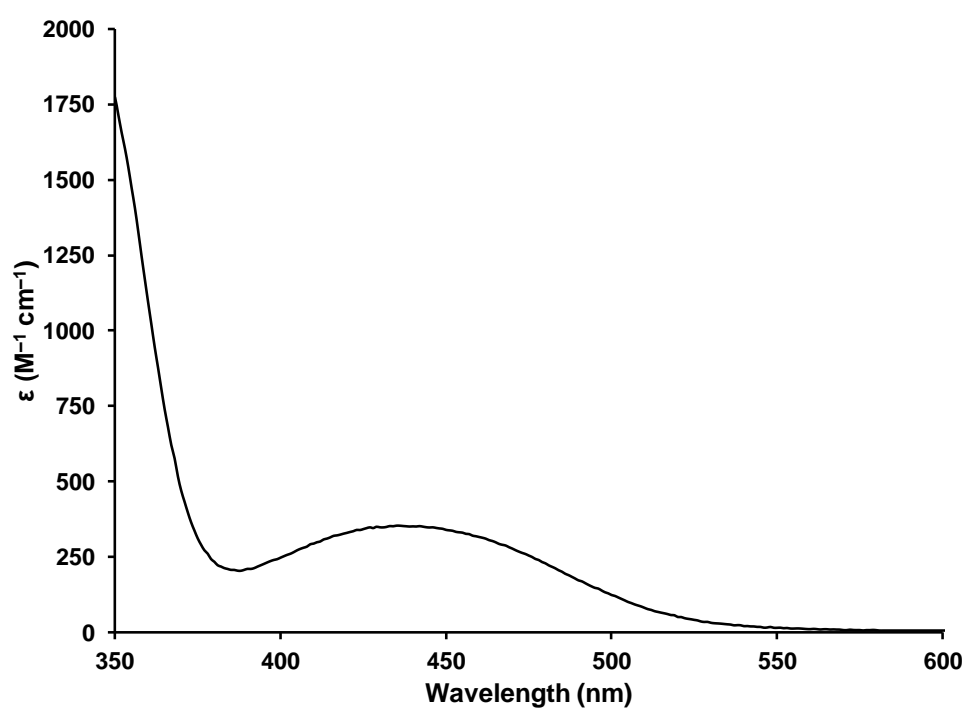

Fig. S50 UV-Vis absorption spectrum of $\mathbf{6 c}$ recorded in $\mathrm{CH}_{2} \mathrm{Cl}_{2}$. 


\section{Cyclic Voltammograms}
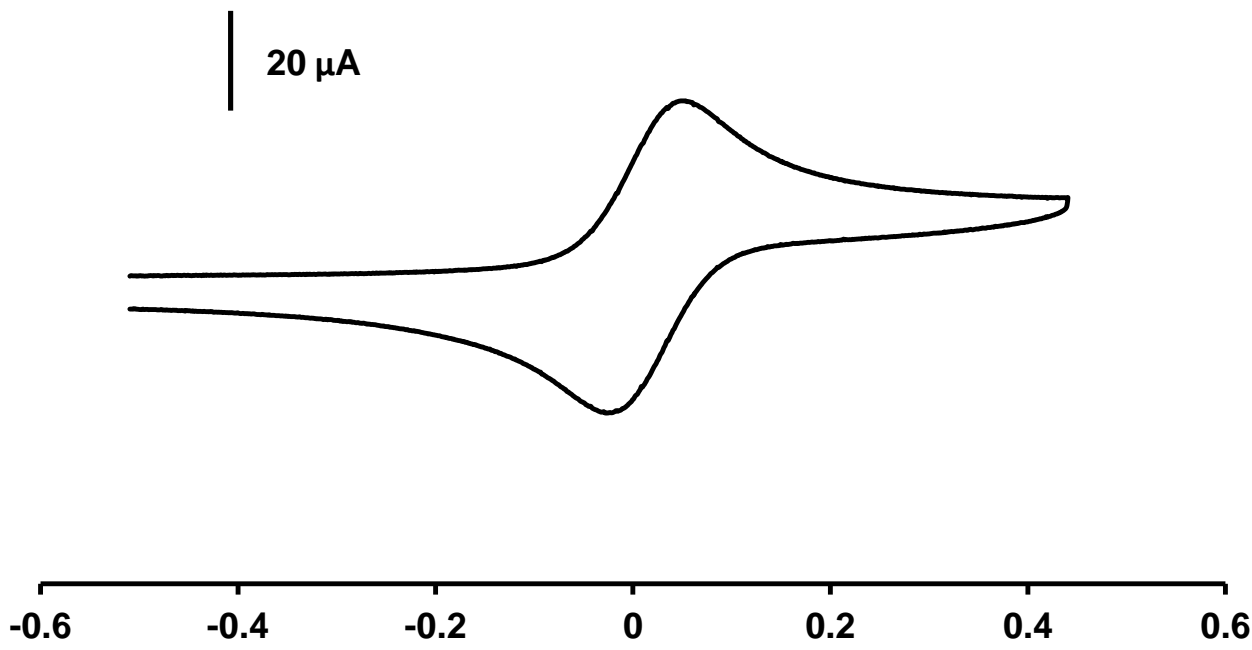

Potential (V vs. Ferrocene/Ferrocenium)

Fig. S51 Cyclic voltammogram of 5a recorded at $250 \mathrm{mV} \mathrm{s}^{-1}$ for a $1 \mathrm{mM}$ degassed 2:1 $\mathrm{CH}_{2} \mathrm{Cl}_{2}: \mathrm{CH}_{3} \mathrm{CN}$ solution containing $0.1 \mathrm{M}\left[n-\mathrm{Bu}_{4} \mathrm{~N}\right]\left[\mathrm{SO}_{3} \mathrm{CF}_{3}\right]$ as supporting electrolyte.

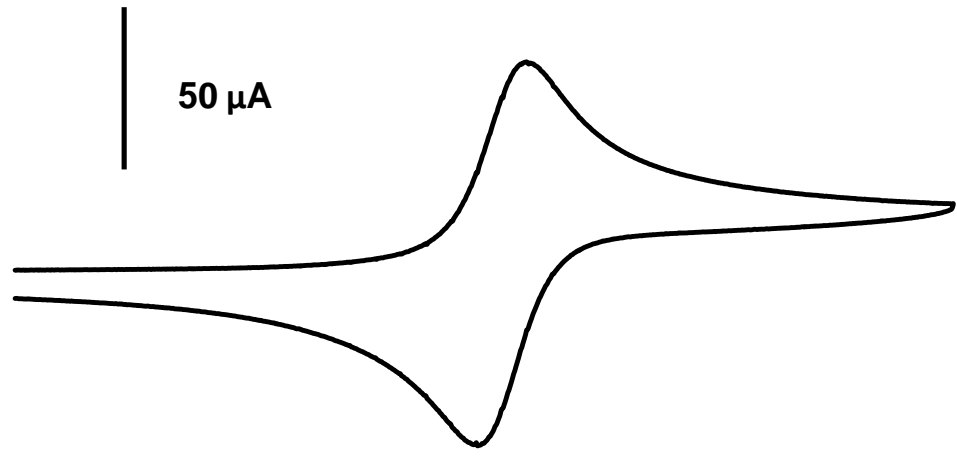

\begin{tabular}{rrrrrrr}
\hline-0.6 & -0.4 & -0.2 & 0 & 0.2 & 0.4 & 0.6
\end{tabular}

Potential (V vs. Ferrocene/Ferrocenium)

Fig. S52 Cyclic voltammogram of $\mathbf{5 b}$ recorded at $250 \mathrm{mV} \mathrm{s}^{-1}$ for a $1 \mathrm{mM}$ degassed 2:1 $\mathrm{CH}_{2} \mathrm{Cl}_{2}: \mathrm{CH}_{3} \mathrm{CN}$ solution containing $0.1 \mathrm{M}\left[n-\mathrm{Bu}_{4} \mathrm{~N}\right]\left[\mathrm{SO}_{3} \mathrm{CF}_{3}\right]$ as supporting electrolyte. 


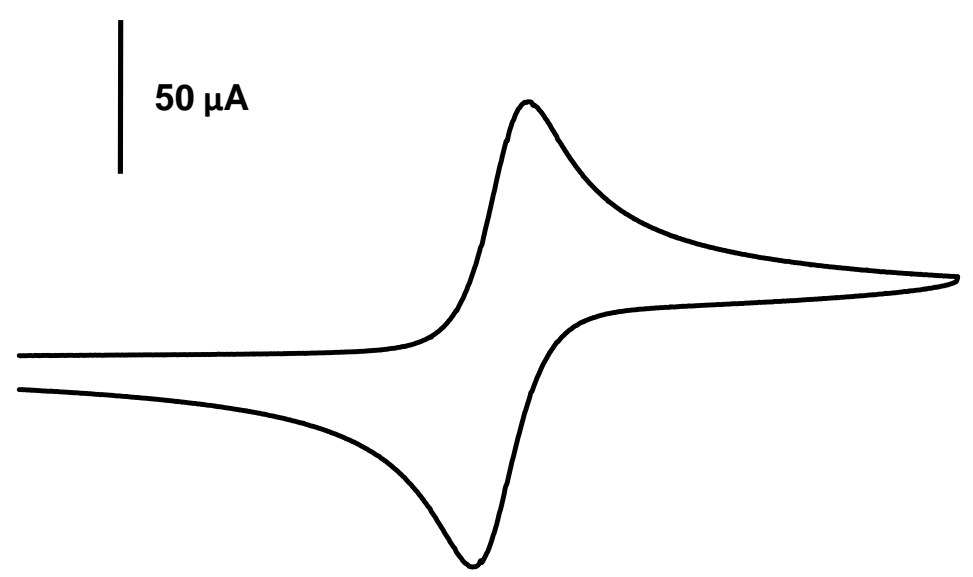

\begin{tabular}{lllllll}
\hline-0.6 & -0.4 & -0.2 & 0 & 0.2 & 0.4 & 0.6
\end{tabular}

Potential (V vs. Ferrocene/Ferrocenium)

Fig. S53 Cyclic voltammogram of $\mathbf{5 c}$ recorded at $250 \mathrm{mV} \mathrm{s}^{-1}$ for a $1 \mathrm{mM}$ degassed 2:1 $\mathrm{CH}_{2} \mathrm{Cl}_{2}: \mathrm{CH}_{3} \mathrm{CN}$ solution containing $0.1 \mathrm{M}\left[n-\mathrm{Bu}_{4} \mathrm{~N}\right]\left[\mathrm{SO}_{3} \mathrm{CF}_{3}\right]$ as supporting electrolyte.

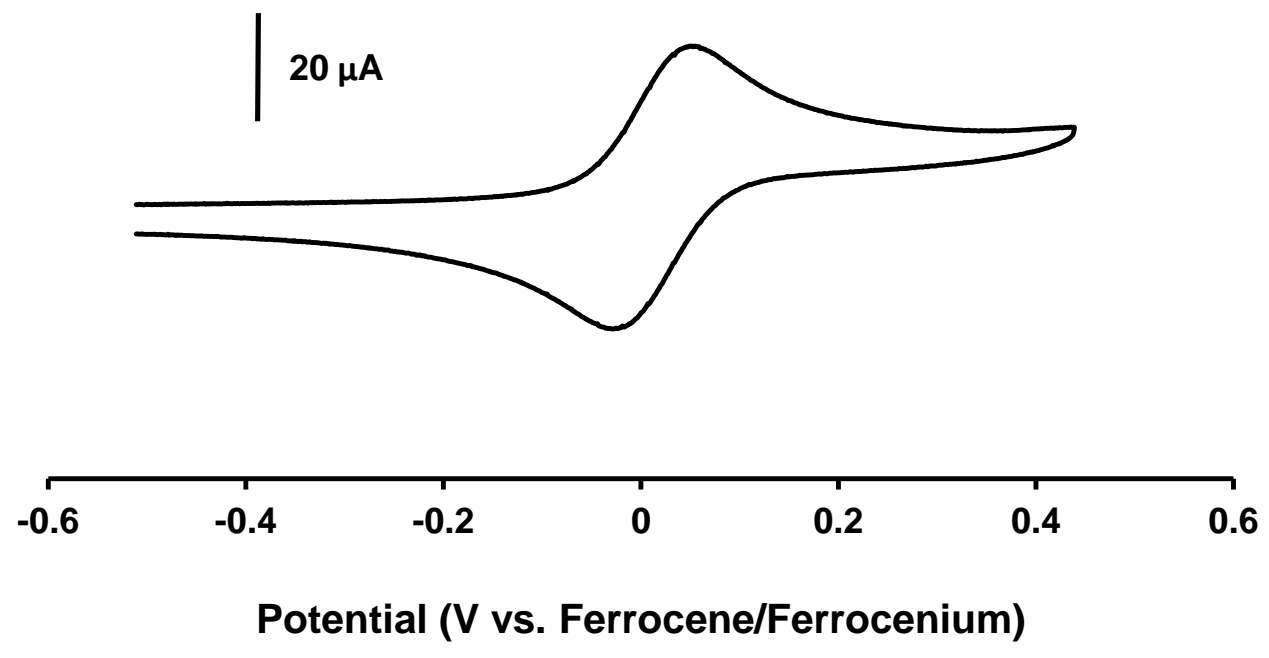

Fig. S54 Cyclic voltammogram of $\mathbf{6 a}$ recorded at $250 \mathrm{mV} \mathrm{s}^{-1}$ for a $1 \mathrm{mM}$ degassed 2:1 $\mathrm{CH}_{2} \mathrm{Cl}_{2}: \mathrm{CH}_{3} \mathrm{CN}$ solution containing $0.1 \mathrm{M}\left[n-\mathrm{Bu}_{4} \mathrm{~N}\right]\left[\mathrm{SO}_{3} \mathrm{CF}_{3}\right]$ as supporting electrolyte. 

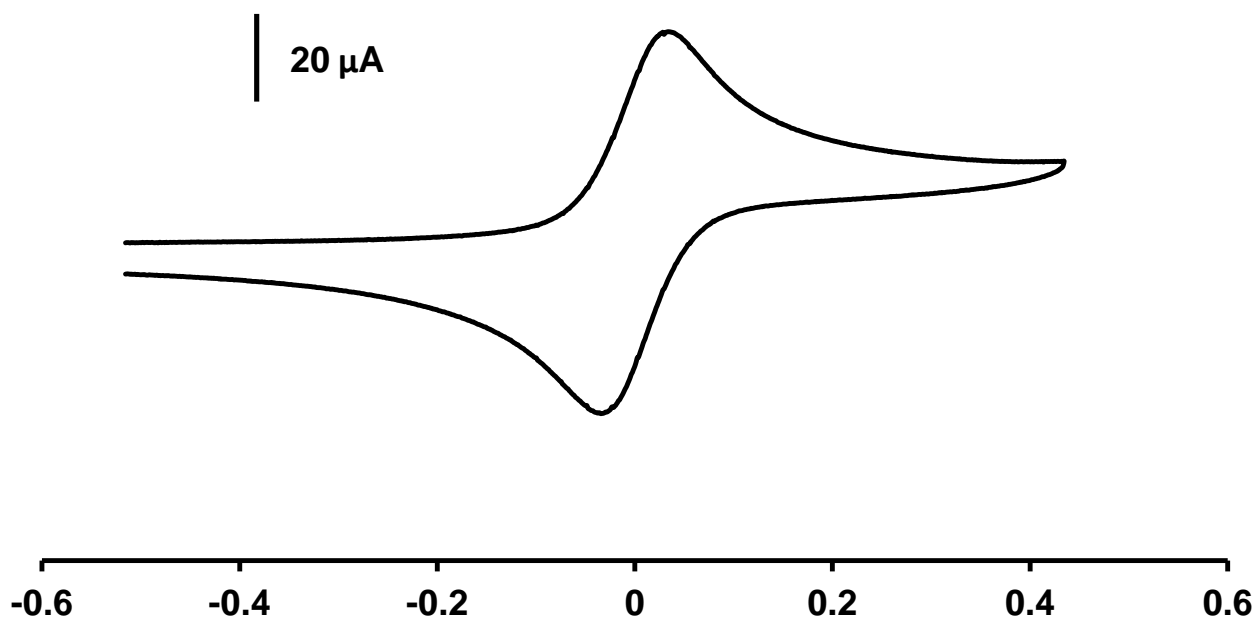

Potential (V vs. Ferrocene/Ferrocenium)

Fig. S55 Cyclic voltammogram of $\mathbf{6 b}$ recorded at $250 \mathrm{mV} \mathrm{s}^{-1}$ for a $1 \mathrm{mM}$ degassed 2:1 $\mathrm{CH}_{2} \mathrm{Cl}_{2}: \mathrm{CH}_{3} \mathrm{CN}$ solution containing $0.1 \mathrm{M}\left[n-\mathrm{Bu}_{4} \mathrm{~N}\right]\left[\mathrm{SO}_{3} \mathrm{CF}_{3}\right]$ as supporting electrolyte.
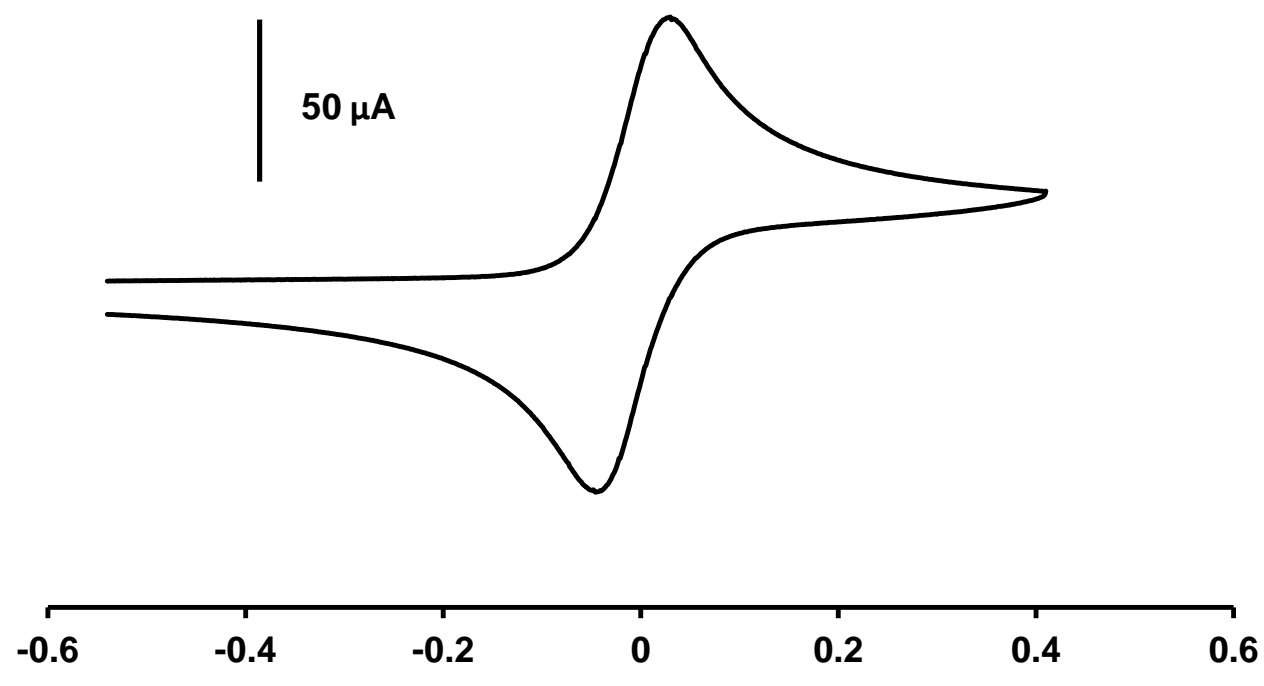

Potential (V vs. Ferrocene/Ferrocenium)

Fig. S56 Cyclic voltammogram of $\mathbf{6 c}$ recorded at $250 \mathrm{mV} \mathrm{s}^{-1}$ for a $1 \mathrm{mM}$ degassed 2:1 $\mathrm{CH}_{2} \mathrm{Cl}_{2}: \mathrm{CH}_{3} \mathrm{CN}$ solution containing $0.1 \mathrm{M}\left[n-\mathrm{Bu}_{4} \mathrm{~N}\right]\left[\mathrm{SO}_{3} \mathrm{CF}_{3}\right]$ as supporting electrolyte. 

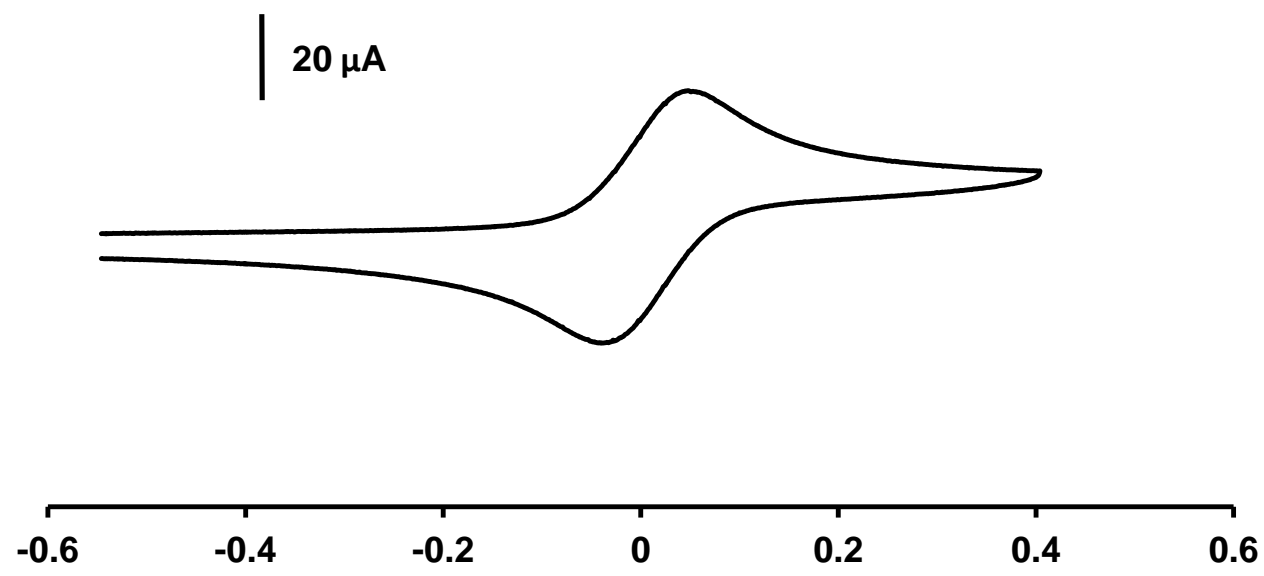

Potential (V vs. Ferrocene/Ferrocenium)

Fig. S57 Cyclic voltammogram of 7a recorded at $250 \mathrm{mV} \mathrm{s}^{-1}$ for a $1 \mathrm{mM}$ degassed 2:1 $\mathrm{CH}_{2} \mathrm{Cl}_{2}: \mathrm{CH}_{3} \mathrm{CN}$ solution containing $0.1 \mathrm{M}\left[n-\mathrm{Bu}_{4} \mathrm{~N}\right]\left[\mathrm{SO}_{3} \mathrm{CF}_{3}\right]$ as supporting electrolyte.
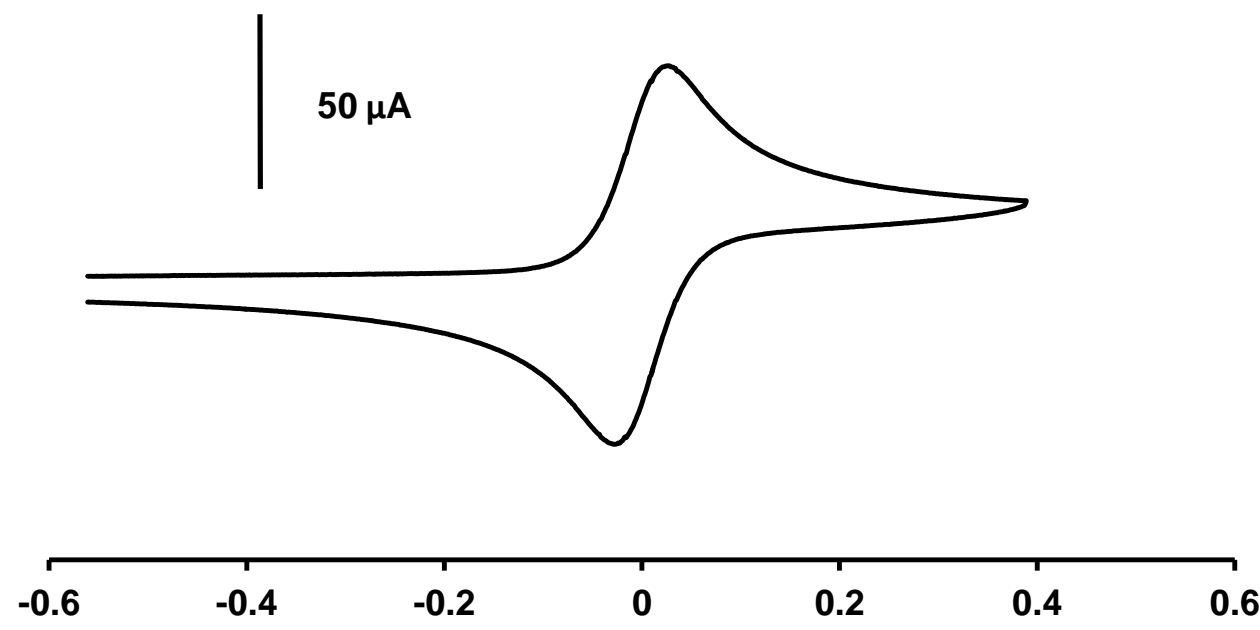

Potential (V vs. Ferrocene/Ferrocenium)

Fig. S58 Cyclic voltammogram of $\mathbf{7 b}$ recorded at $250 \mathrm{mV} \mathrm{s}^{-1}$ for a $1 \mathrm{mM}$ degassed 2:1 $\mathrm{CH}_{2} \mathrm{Cl}_{2}: \mathrm{CH}_{3} \mathrm{CN}$ solution containing $0.1 \mathrm{M}\left[n-\mathrm{Bu}_{4} \mathrm{~N}\right]\left[\mathrm{SO}_{3} \mathrm{CF}_{3}\right]$ as supporting electrolyte. 